\title{
Speleothem microstructure/speleothem ontogeny: a review of Western contributions
}

\author{
William B. White ${ }^{1}$
}

\begin{abstract}
:
White W.B. 2012. Speleothem microstructure/speleothem ontogeny: a review of Western contributions. International Journal of Speleology, 41(2), 329-358. Tampa, FL (USA). ISSN 0392-6672. http://dx.doi.org/10.5038/1827-806X.41.2.18

Mineral ontogeny is the study of the growth and development of mineral deposits in general and, in the present context, speleothems in particular. Previous researchers, mainly in Russia, have developed a nomenclatural hierarchy based on the forms and habits of individual crystals and the assembly of individual crystals into both monomineralic and polymineralic aggegates (i.e. speleothems). Although investigations of the growth processes of speleothems are sparse, there is a large literature on growth processes of speleothem minerals and related crystals in the geochemical and materials science literature. The purpose of the present paper is to sort through the various concepts of crystal growth and attempt to relate these to observations on speleothems and to the Russian conceptual framework of mineral ontogeny. For calcite, the most common mineral in speleothems, the activation energy for two dimensional nucleation (required for the growth of large single crystals) is almost the same as the activation energy for threedimensional nucleation (which would result in the growth of many small crystals). Calcite growth is highly sensitive to minor impurities that may poison growth in certain crystallographic directions or may poison growth altogether. Extensive recent research using the atomic force microscope (AFM) provides many details of calcite growth including the transition from growth on screw dislocations to growth by two-dimensional nucleation. The deposition of aragonite speleothems requires metastable supersaturation curve and is usually ascribed to the impurities $\mathrm{Mg}^{2+}$ and $\mathrm{Sr}^{2+}$. AFM studies reveal that $\mathrm{Mg}^{2+}$ poisons calcite growth by blocking deposition sites on dislocations, thus allowing supersaturation to build up past the aragonite solubility curve. Sr ${ }^{2+}$ precipitates as a Sr-rich nucleus with the aragonite structure which acts as a template for aragonite growth. The different morphology of gypsum speleothems can be explained by the different growth habit of gypsum. Examples of twinned growth, dendrite growth, and spherulitic growth are common in the crystal growth literature and can be used to interpret the corresponding cave forms. Interpretation of monomineralic aggregate growth follows from individual crystal mechanisms. Interpretation of polymineralic aggregate growth requires knowing the evolving chemistry which in turn requires new methods for the sampling and analysis of microliter or nanoliter quantities of fluid.
\end{abstract}

Keywords: ontogeny; crystal growth; speleothems; calcite; aragonite; gypsum

Received 24 April 2012; Revised 20 June 2012; Accepted 2 July 2012

\section{INTRODUCTION}

Caves are wonderful laboratories in which to study the growth of crystals. The environmental conditions of temperature and water vapor partial pressure remain precisely constant for very long periods of time. Carbon dioxide partial pressures and rates of infiltrating water often cycle seasonally or fluctuate with storm flow but between well-defined limits. In caves, time, which is an essential parameter for the growth of large crystals, is in abundant supply. As a result, the crystals that make up speleothems occur on size scales from millimeters to many centimeters (or many meters in the case of the Naica gypsum crystals (Badino et al., 2011). Because growth is into the

${ }^{1}$ Materials Research Institute and Department of Geosciences, The Pennsylvania State University, University Park, PA 16802 USA (wbw2@psu.edu) open cave passage, crystals are free to develop whatever morphology is demanded by their growth mechanisms. The end results are the myriad speleothem shapes that form the subjects for the many dazzling photographs that have been taken in caves.

Studies of cave minerals in the West - "West" here referring mostly to the United States, Canada, and Western Europe - have focused on five aspects of the subject:

1. The identification of minerals that occur in caves. As of 1997 when Hill and Forti published their monumental treatise on cave minerals, more than 250 minerals had been identified as forming in the cave environment (Hill \& Forti, 1997). The most recent compilation brings the number to 319 (Onac $\&$ Forti, 2011a). Of these, calcite, aragonite, and gypsum are the most common and their growth is the subject of this review. 
2. At macro scales, the description and distribution of speleothems. There have been numerous attempts to describe and classify speleothems according to their external form. Because of their intrinsic esthetic value, cave photographers have accumulated a very large, if informal, data base on the external forms of speleothems.

3. The geochemical mechanisms responsible for the deposition of cave minerals. These studies include equilibrium chemical reactions and precipitation kinetics and also include bulk growth rates for some speleothems. These investigations would be called phylogeny in the Russian literature. Examples would be Holland et al.'s (1964) model for carbonate mineral deposition in caves and also calculations on the thermodynamic stability of a variety of carbonate and sulfate minerals (White, 1997).

4. Use of speleothem microstratigraphy, isotope and trace element profiles, and luminescence and color banding as paleoclimatic records. This is a very active area of research and has implications that go far outside of cave-related sciences (Perrette, 1999; McDermott, 2004; White, 2004; Fairchild \& Treble, 2009; Fairchild \& Baker, 2012).

5. Cave mineral ontogeny. Only sparsely represented on this list of investigations are studies of the interrelationships between the individual mineral crystals and the macroscopic speleothem - that is, studies that take into account growth mechanisms and kinetics of growth with respect to crystallographic directions in mineral crystals.

It is precisely the investigation of the intermediate scale structures that has occupied the attention of Russian mineralogists and which has been described as the ontogeny of cave minerals. The term "ontogeny" (spelled "onthogeny" by Maltsev (1997)) is borrowed from biology and refers to the forms and interrelationships of the mineral crystals that make up the overall mineral body. Much of this work has been hidden behind language barriers. Recently accounts in English have begun to appear as translations of books (Grigor'ev, 1965) and in journals (Maltsev, 1997; Stepanov, 1997, 1999; Slyotov, 1999; Self \& Hill, 2003, 2005) making possible a critical evaluation of the concepts. The hierarchy of forms, as summarized by Self $\&$ Hill (2005) (Table 1) will serve as a guide for the discussion. Descriptions and photographs of each of the forms are given in Self \& Hill (2003).

More controversial is the claim that mineral ontogeny is a distinctly different and wide-ranging branch of genetic mineralogy which is largely unknown in the West (a claim made by Maltsev (1997) and by Self \& Hill (2003)). With respect to speleothems, it is certainly true that relatively little has been reported on the interrelationships of the crystals that make up speleothems although there have been some textural and petrographic investigations (Folk \& Assereto, 1976; Cabrol, 1978; Kendall \& Broughton, 1978; Ghergari \& Onac, 1995; Railsback 2000; Frisia et al., 2000). It is discouraging that the most comprehensive de- scription of speleothem external forms and internal crystalline arrangements was written more than 100 years ago (Prinz, 1908). With respect to mineralogy in general and with respect to growth of synthetic crystals for various technological applications this claim is certainly not true. Grigor'ev's book contains much of the same information found in English language books on crystal growth except that the emphasis is on minerals rather than synthetic crystals.

The objective of the present review is to sort through the crystal growth and related literature and locate information that may relate to speleothems. This in turn can be compared to the Russian conceptual framework of mineral ontogeny. There is, as expected, a quite large literature on the growth of the primary cave minerals calcite, aragonite, and gypsum although not with regard to their occurrence in caves.

Table 1. The hierarchy of mineral ontogeny (from Hill and Self, 2005)

0. ZERO LEVEL: Subindividuals

1. FIRST LEVEL: Mineral Individuals

1.1 First-order individuals

1.2 Second-order individuals

1.2.1 Split crystals

1.2.1A Spherulites

1.2.1B Spherulite bunches

1.2.1C Discospherulites

1.2.1D Spheroidalites

1.2.1E Spherocrystals

1.2.2 Skeleton crystals

1.2.3 Twin crystals

1.2.4 Screw crystals

1.2.5 Block crystals

1.2.6 Complex

2. SECOND LEVEL: Assemblages of Individuals

2.1 Aggregates

2.1.1 Parallel-columnar aggregates

2.1.2 Spherulitic aggregates

2.1.2A Core spherulites

2.1.2B Irregular spherulites

2.1.3 Radial-fibrous aggregates

2.1.4 Branching aggregates

2.1.4A Corallites

2.1.4B Crystallictites

2.1.5 Fibrous aggregates

2.1.6 Interactive aggregates

2.1.7 Other aggregates

2.2 Multiaggregates

2.2.1 Polymineral multiaggregates

2.2.2 Polytextural multiaggregates

2.2.3 Hybrid multiaggregates

2.3 Pseudoaggregates

2.3.1 Tufaceous mineral bodies

2.3.2 Moonmilk

3. THIRD LEVEL: Assemblages of Aggregates

3.1 Koras

4. FOURTH LEVEL: Assemblages of Koras

4.1 Ensembles

\section{SOME HISTORICAL BACKGROUND}

Because ontogeny and phylogeny of minerals divided into separate fields of study in Russia in the 1920's (Maltsev, 1997; Self \& Hill, 2003), it is helpful to begin the historical record somewhat farther back in time. The interesting question is why the subject 
separated in Russia but not (?) in the West. Here follows a few historical milestones, the early ones drawn from von Laue (1965).

The roots of crystallography run deep. The external symmetry of crystals had been noted since ancient times. Discovery of the invariance of interfacial angles dates back to Niels Stensen in 1669 and generalized by Jean-Babtiste L. Romé de L'Isle in 1772. By 1830 J.F.C. Hessel had classified naturally occurring crystals according to their symmetry and had identified the 32 crystal point groups. This permitted the construction of a systematic crystallography based on the external forms of crystals (e.g. Naumann, 1856). The concept of the space lattice is even older (there are hints of it in a pamphlet written by Johannes Kepler in 1611) but evolved more slowly so that by 1850 Moritz L. Frankenheim and August Bravais had described the 14 space lattices possible in three dimensions that correspond to the 32 crystal point groups. The infinite lattice admits more symmetry operations (now known as screw axes and glide planes) than are possible for point symmetries. The complete problem, connecting the Bravais lattices with all possible symmetry operations, was solved independently in 1890 by Evgraph S. Fedorov and Artur Schoenflies. The result was the 230 space groups which form the basis for crystallography.

Mineralogy in these early years consisted of identifying possible new mineral species by bulk chemical analysis and by the external habit of the crystals. One primary motivation for the chemical analyses was the possibility of discovering new elements. The concept of the periodic table was being constructed over the same time interval that the mathematical foundations of crystallography were being laid.

It is important to understand that in 1890 , when the essential mathematical structure of crystallography was complete, not only was the internal structure of crystals unknown but even the existence of atoms was still in dispute. Atoms were regarded by many as simply a bookkeeping device that allowed the chemists to balance their reactions. There had been much speculation about the internal make-up of crystals but there was no experimental method to distinguish between the many hypotheses. The breakthrough that made crystallography an experimental science rather than a branch of mathematics was Roentgen's discovery of X-rays in 1895 . That breakthrough sent crystallography off in a new direction. Based on the fundamental investigations of Felix Theodor von Laue and his co-workers Paul Knipping and Walther Friedrich in 1912, by 1913 techniques had been developed, mainly by William and Lawrence Bragg, to determine the atomic arrangement in crystals through the diffraction of X-rays. One of the earliest crystals to be analyzed was calcite by W.L. Bragg (1914). Crystal structure determination became a core part of mineralogy and has remained so to the present. "Descriptive mineralogy" now included a determination of the crystal structure of proposed new minerals.

Also in the late 1800's the recently developed science of physical chemistry was being applied to the solubility, stability, and phase relations of mainly water-soluble minerals (see, e.g. Eugster, 1971). Many of these investigations remain relevant today because they apply to the deposition of many carbonate and sulfate minerals in caves. Techniques for phase equilibrium investigations at high temperatures came in the early 1900's and still later, in the 1930's, to mineral equilibria in hydrothermal systems. These concepts and techniques form the basis for what has been called mineral phylogeny.

Although new theoretical concepts and new experimental techniques offered the most exciting advances in mineralogy, they were not the primary reason for the decrease in the study of bulk crystals, their growth, and their interrelationships (i.e. mineral ontogeny). It was recognized that any given mineral would be described by only one of the 32 crystal symmetries and belong to only one of the 230 space groups, so there was the difficult question of why the same mineral frequently appeared in many different crystal habits. Why, for example, does calcite frequently occur in caves as the scalenohedon (dogtooth spar) but in some caves as the rhombohedron (nail-head spar)? Calcite, in fact, has the largest number of distinct forms of any mineral; 600 forms have been claimed (Whitlock, 1909; Palache, 1943). Photographs of some spectacular examples were published by Huizing et al., (2003).

The various habits arise because of differing growth rates in different crystallographic directions. Sorting out what controls growth and habit attracted attention from a number of prominent scientists in the late $19^{\text {th }}$ Century including Daniel and Pierre Curie. It was relating the structure of crystals to their physical properties (mainly electrical and magnetic) that led Pierre Curie to the famous Curie groups - sets of symmetry operations of higher order than the 32 crystallographic point groups. The reason why investigations of crystal growth morphology and crystal habit were largely abandoned is that the investigations were going nowhere. Growth rates of individual crystal faces, nucleation of additional crystals, twinning, splitting, and other processes responsible for mineral ontogeny all depend on details of surface structure and adsorbed impurities on the growing surfaces. The effect of impurities was particularly frustrating because there were obvious effects but these were often irreproducible and erratic. In the late $19^{\text {th }}$ Century and early $20^{\text {th }}$, there were neither experimental tools nor enough control over chemical purity to make sense out of the results of the many crystal growth experiments. Many investigators found more rewarding topics on which to invest their time although a few kept on. Discoveries of importance included various mathematical models for crystal growth and the discovery of crystal dislocations. The latter were first revealed by the investigations of etch pits by Arthur P. Honess (1927). The discovery of dislocations, particularly screw dislocations, provided an important component to the study of crystal growth mechanisms and extended the theory that was based on classical thermodynamics (Burton et al., 1951). The pre-World War II state-of-the-art is summarized in considerable detail by Buckley (1951).

The problems, of course, did not go away but instead underwent a change of venue. The driving force was no longer basic science questions in mineralogy, but the practical need to grow crystals of materials 
required by the fledgling electronics industry. Three crystals stand out in the pre-war years: quartz, Rochelle salt (potassium sodium tartrate) and potassium dihydrogen phosphate (KDP). Single crystal quartz was, and still is, used as a frequency stabilizer in electronic oscillators. The latter two crystals are piezoelectric and were used as transducers, converting mechanical vibrations into electrical signals in early phonographs, microphones and other applications. In the immediate post-war years there developed an even larger demand for high quality single crystals: Quartz certainly, also silicon and germanium for transistors and later chips for integrated circuits, ruby and sapphire for lasers, III-V compounds (GaAs, GaP, InN etc) as semiconductors and as diode lasers and light emitting diodes - the list is a very long one. There was a huge renaissance in crystal growth research beginning in the 1960's including the establishment of journals devoted entirely to publishing papers on crystal growth (see e.g. Peiser, 1966). Cave minerals may not have received much attention but many other materials certainly did.

The heyday of crystal growth research extended from the 1950's to the 1980's with many of the basic principles set down as early as the 1940's. Because many of the technologically important crystals are refractory, the methods included growth by cooling the melt, growth from high temperature molten salt solvents, growth from hydrothermal solutions, and growth from the vapor. Growth from ambient temperature aqueous solutions was relatively less important although there were some exceptions such as the growth of triglycine sulfate, an infrared detector material. For a sense of this very large and complex enterprise see Gilman (1963) and Bardsley et al. (1979).

Invention of new experimental tools, especially the scanning electron microscope and the atomic force microscope, and the development of computer programs for molecular dynamics simulations of high precision, have allowed investigators to return to problems involving the mineral-water interface, especially the adsorption of impurities. For the beginnings of this new visitation of interface problems see the collection of review articles edited by M.F. Hochella $\&$ A.F. White (1990). They may not be called mineral ontogeny, but investigations of mineral surfaces and the growth of new crystals on them is a booming enterprise today. Some of these new results, especially with regard to the growth of calcite, will appear in sections that follow.

\section{THE GEOCHEMISTRY OF CRYSTAL GROWTH IN CAVES}

Minerals in caves are deposited by a variety of geochemical mechanisms depending on the lithology of the bedrock, on the temperature, and on the transport mechanisms. Thus one could consider minerals in volcanic caves, in sandstone caves, and in hypogenetic caves where highly reducing, sulfide-bearing solutions may be the transporting agents (Onac \& Forti, $2011 b)$. The discussion in the present paper is limited to the low temperature, aqueous environment of solution caves in carbonate and gypsum rocks.

Minerals in karst caves form by precipitation from aqueous solutions, usually under isothermal condi-

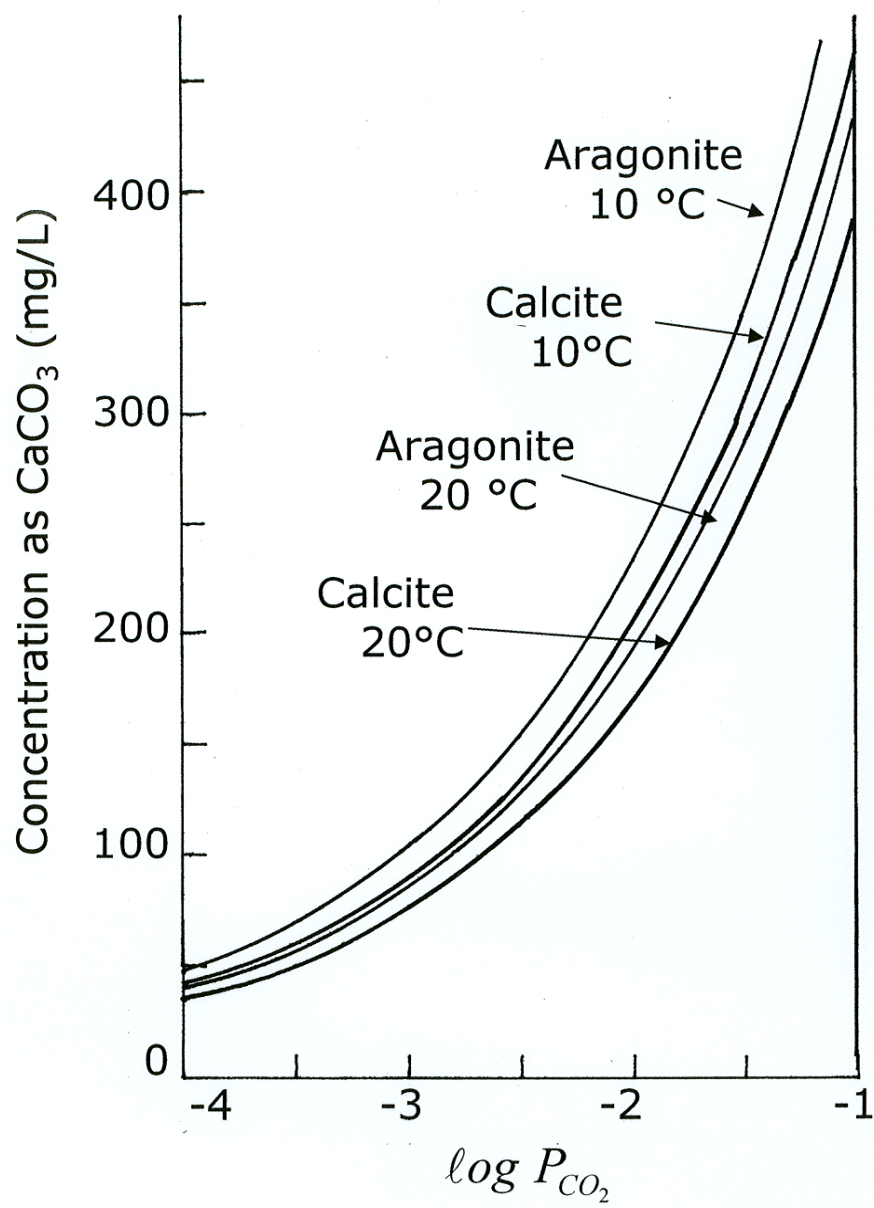

Fig. 1. Solubility curves for calcite and aragonite as a function of $\mathrm{CO}_{2}$ pressure at 10 and $20^{\circ} \mathrm{C}$. These curves were calculated using the equilibrium constants of Plummer \& Busenberg (1982).

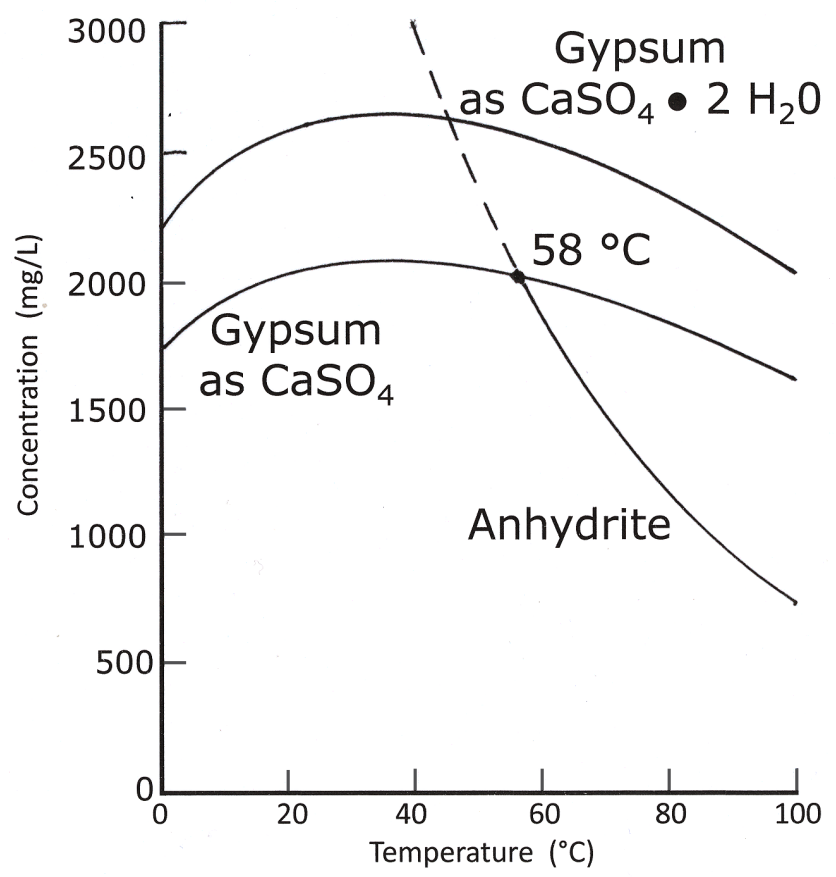

Fig. 2. Solubility curves for $\mathrm{CaSO}_{4}$ expressed both as $\mathrm{CaSO}_{4}$ and as gypsum. Note inversion to anhydrite at $58{ }^{\circ} \mathrm{C}$. These solubility curves were calculated from the empirical equations of Blount \& Dickson (1973). 
tions. The solubilities of the carbonate minerals calcite and aragonite depend on carbon dioxide pressure and temperature (Fig. 1) and also on the ionic strength of the solution. The latter is responsible for mixing zone dissolution and the formation of halocline caves. As can be seen from Fig. 1, the calcite and aragonite solubility isotherms overlap. Aragonite is more soluble than calcite but not a great deal more soluble. Precipitation of either phase at constant temperature can be achieved by loss of carbon dioxide. The carbonate phases can also be precipitated by loss of solvent (evaporation).

The precipitation of gypsum is simply the recombination of calcium and sulfate ions with no chemistry involved and no dependence on the $\mathrm{CO}_{2}$ pressure. Gypsum precipitation is achieved under isothermal conditions by loss of solvent. Gypsum solubility is a rather strange function of temperature (Fig. 2). Account must also be taken of the possible dehydration of gypsum to anhydrite. In addition to the effect of temperature, solutions of high ionic strength, which reduces the activity of water, can also precipitate anhydrite. The intermediate phase bassanite, $\mathrm{CaSO}_{4} \cdot 1 / 2 \mathrm{H}_{2} \mathrm{O}$, does not usually appear in the cave environment.

The driving force for any crystal growth is supersaturation. That is, the concentration of dissolved species in solution must be higher than the equilibrium solubility. The concentrations of dissolved carbonate in supersaturated solutions would plot to the left of the equilibrium solubility curves in Fig. 1. Different investigators use many different definitions of supersaturation (and likewise are not consistent in their choice of symbols). Commonly used in the crystal growth literature is supersaturation written in terms of concentration

$$
\sigma=\frac{C-C_{O}}{C_{O}} \quad \text { or } \quad \sigma=\frac{C}{C_{0}}
$$

$\mathrm{C}$ is the solution concentration of the ions that form the growing crystal and $\mathrm{C}_{\mathrm{O}}$ is the equilibrium concentration.

Equation (1) can also be written as the ratio of mole fraction of solute, $\mathrm{X}_{\mathrm{i}}$, compared with the mole fraction of solute in solution at equilibrium, $X_{0}$.

$$
\alpha=\frac{X_{i}}{X_{0}}
$$

Supersaturation can be defined as the saturation ratio which for calcite is

$$
\Omega=\frac{a_{\mathrm{Ca}^{2+}} a_{\mathrm{CO}_{3}^{2-}}}{K_{\mathrm{C}}}
$$

As a fourth alternative, the saturation state can be written as the saturation index

$$
S I_{C}=\log \Omega=\log \frac{a_{\mathrm{Ca}^{2+}} a_{\mathrm{CO}_{3}^{2-}}}{K_{C}}
$$

Equation (4) is also written as the natural logarithm of $\Omega$ rather than the base-10 logarithm. In equations (3) and (4) $\mathrm{K}_{\mathrm{C}}$ is the solubility product constant for calcite which is a function of temperature. The su- persaturation with respect to aragonite would be obtained by replacing $\mathrm{K}_{\mathrm{C}}$ with $\mathrm{K}_{\mathrm{A}}$, the solubility product constant for aragonite. The a's are thermodynamic activities for $\mathrm{Ca}^{2+}$ and $\mathrm{CO}_{3}{ }^{2-}$ respectively. Activities are the thermodynamically ideal concentrations. They are related to the actual chemical concentrations through the activity coefficients. For any species, i,

$$
a_{i}=\gamma_{i} m_{i}
$$

The concentrations, $\mathrm{m}_{\mathrm{i}}$, are usually given in molal units. The activity coefficients, $\gamma_{i}$, depend on the ionic strength of the solutions and can be calculated by geochemical methods (e.g. Langmuir, 1997).

The saturation state for gypsum could also be written in any of these ways except that concentrations or activities of $\mathrm{Ca}^{2+}$ and $\mathrm{SO}_{4}{ }^{2-}$ would enter the equations.

\section{CONCEPTS OF CRYSTAL NUCLEATION AND CRYSTAL GROWTH}

The precipitation of a solid from a homogeneous solution requires two distinct steps. The first is the nucleation step in which the first bit of crystalline solid is organized from the random arrangement of ions or molecules in the parent liquid. The second is the growth step in which additional material is deposited on the existing nucleus. Nucleation may be homogeneous, in which nuclei form directly from the liquid, or it may be heterogeneous in which existing crystal seeds, solid impurities, or the container surface act as initial nuclei on which additional material is deposited.

\section{Classical theory of homogeneous nucleation}

There is an energy barrier to the formation of nuclei since energy is required for the formation of the solid/liquid interface. This is the reason that nucleation must always take place at a finite supersaturation. Supersaturation can be achieved by lowering the temperature (most solids are more soluble in warm solutions than in cold solutions), by evaporating the solvent, or, in the case of calcite and aragonite deposition in caves, by decreasing the solubility of the minerals through de-gassing carbon dioxide.

Derivations of classical nucleation rate follow directly from thermodynamics. There are various formulations; the one given below is from Nancollas \& Purdie (1964). The energy, G, required to form a cluster of radius, $r$, (here assumed to be spherical) contains a surface free energy part (positive) and a volume free energy part (negative).

$$
G=4 \pi r^{2} E_{S}-\frac{4}{3} \pi r^{3} \Delta G_{v}
$$

$\mathrm{E}_{\mathrm{S}}$ is the interfacial surface energy and $\Delta \mathrm{G}_{\mathrm{V}}$ is the Gibbs free energy of the bulk crystal. The surface term destabilizes small clusters so a cluster will only become a stable crystal nucleus at some critical $r_{c}$ where the volume term overrides the surface term. If we differentiate equation (6) and set $\mathrm{dG} / \mathrm{dr}=0$, we can solve for the critical radius in terms of the surface and bulk free energies.

$$
r_{c}=\frac{2 E_{S}}{\Delta G_{v}}
$$


If we now use the definition of supersaturation, $a$, given in equation (2), the size of the critical nucleus can be calculated to be

$$
r_{c}=\frac{2 E_{S} V_{M}}{k_{B} T \ln \alpha}
$$

$\mathrm{V}_{\mathrm{M}}$ is the molar volume of the nucleating species, $\mathrm{k}_{\mathrm{B}}$ is the Boltzmann constant, and $\mathrm{T}$ is the absolute temperature.

An increase in supersaturation decreases the size of the critical nucleus and thus will favor nucleation since statistically there will be more small clusters than large ones. Once a critical nucleus has formed, it will act as a template for the further growth of the crystal. Thus a calcite nucleus will favor calcite growth whereas an aragonite nucleus will favor aragonite growth.

The value of $\Delta \mathrm{G}_{\mathrm{c}}$ for the critical nucleus can be calculated and from it the concentration of nuclei of critical size. From this can be calculated a nucleation rate, defined as the number of critical nuclei generated in a unit volume per second, $\mathrm{J}$ (again following Nancollas \& Purdie, 1964).

$$
J=A \exp \left(-\frac{\Delta G_{c}}{k_{B} T}\right)=A \exp \left(-\frac{16 \pi E_{S}{ }^{3} V_{M}{ }^{2}}{3\left(k_{B} T\right)^{3}(\ln \alpha)^{2}}\right)
$$

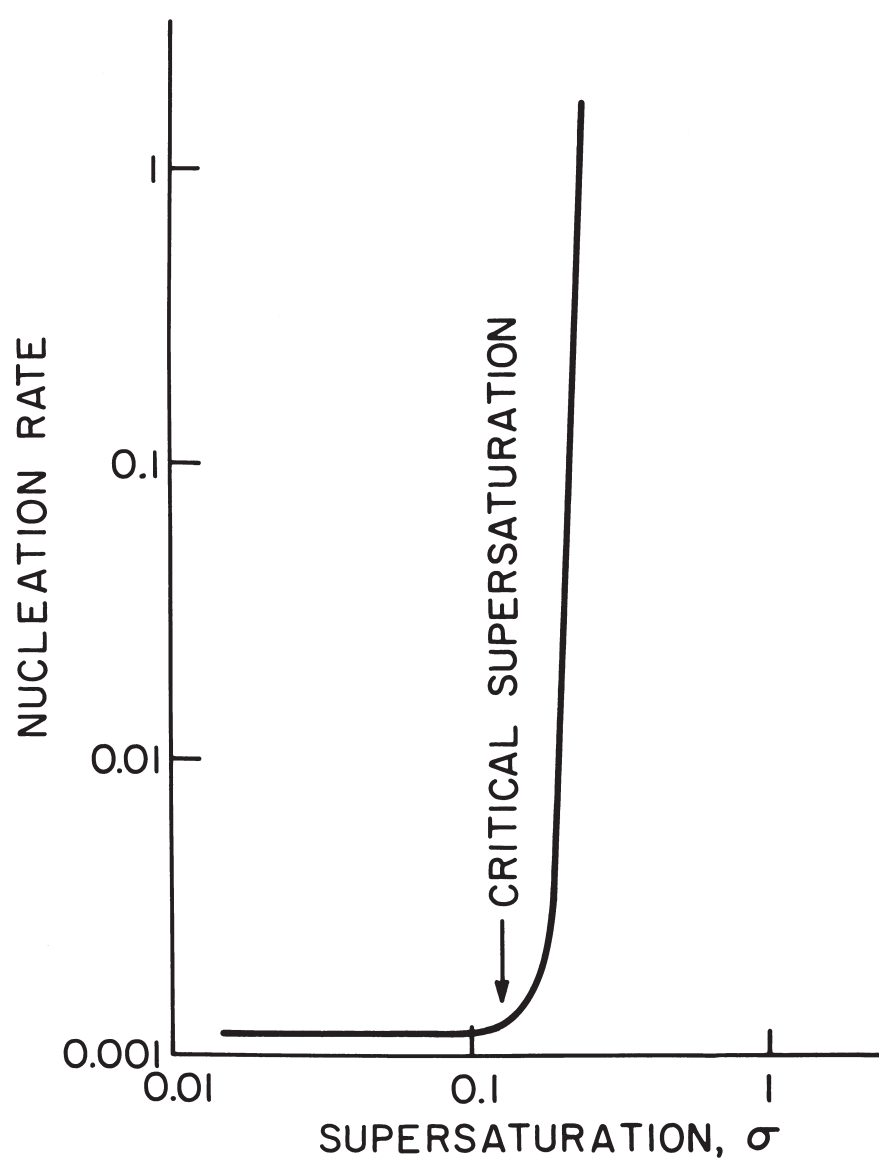

Fig. 3. Plot of nucleation rate as a function of supersaturation. This plot uses $\sigma$ as the definition of supersaturation rather than $\alpha$.
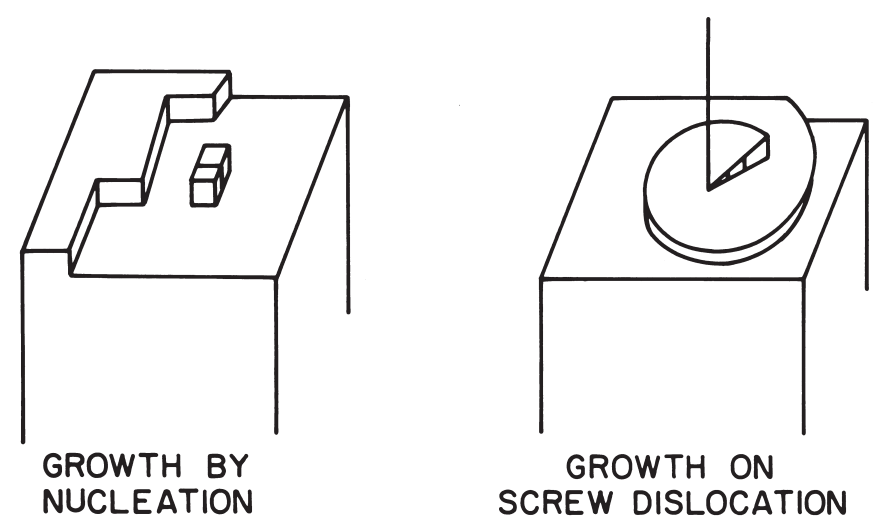

Fig. 4. Sketch showing growth surfaces for (A) two-dimensional nucleation growth and (B) growth on a screw dislocation.

Much of the discussion in the crystal growth literature concerns the nature of the pre-exponential term, A. The lesson to be drawn for the present discussion is that the rate of nucleation is negligible until some critical supersaturation is reached after which nucleation increases extremely rapidly (Fig. 3).

The classical theory of crystal growth is quite elegant but it suffers from a serious flaw: for most cases, it doesn't work. A fundamental assumption of the theory is that the nucleus is a perfect crystal with the same volume free energy as the bulk crystal. Nuclei of most materials including the common cave minerals are highly defective so that the fundamental assumption breaks down. The theory provides a good conceptual model but is not very helpful for quantitative calculations.

\section{Heterogeneous nucleation}

A heterogeneous nucleus is any substance surface or particle - which can form a substrate on which the crystal of interest may be deposited. Heterogeneous nuclei are effective because they lower the energy barrier that would otherwise inhibit homogeneous nucleation. Heterogeneous nuclei are particularly effective when they have the same structure as the growing crystal in which case the overgrowth is called epitaxy. Sometimes quite different structures provide low energy sites on which the components of the crystal can deposit. Such structures are referred to as templates.

It is possible to use pre-existing particles of the desired phase as "seeds" on which larger crystals can be grown. Seeded growth is frequently used in crystal growth experiments. Use of seeds or templates is particularly helpful in growing large single crystals because the nucleation step is bypassed, allowing the growth of a few large crystals instead of the many small ones that would result from spontaneous nucleation.

\section{Growth by two-dimensional nucleation and growth on screw dislocations}

Two mechanisms of crystal growth are illustrated schematically in Fig. 4. If the growing crystal is perfect, ions drift down onto the growing face, move across the surface to an advancing layer of atoms, and attach themselves in perfect crystallographic register (Fig. 4A). When a layer of atoms is completed, a new layer must be started, and this process also requires 
a finite supersaturation because the next layer must be created through a process of two-dimensional nucleation. Once the two-dimensional nucleus has been formed, it provides low energy sites along its boundaries for the deposition of ions; completion of the layer requires much less driving force than the initial formation of the two dimensional nucleus.

Imperfect crystals contain regions of misaligned atoms known as dislocations. Screw dislocations take the form of spiral ramps (Fig. 4B) which in effect provide a never-ending ledge for the low energy deposition of atoms. For more information concerning growth on screw dislocations see Zhang \& Nancollas, (1990). Growth on screw dislocations requires much lower supersaturation than does growth by two-dimensional nucleation and accounts for much of the discrepancy between experimental growth rates and the classical theory. The emergence of the screw dislocations from the crystal surfaces are also highly favorable sites for the adsorption of impurities. Thus crystal growth by this mechanism is especially sensitive to the presence of inhibitors or growth poisons which can be effective at very low concentrations (Sears, 1958).

The end product of mineral deposition may be a single crystal in which all deposition has taken place on a single nucleus or it may be a mass of small crystals. If growth takes place at high supersaturation, it will be energetically favorable to form many nuclei and the end product will be a polycrystalline mass. If the supersaturation is sufficient for two-dimensional nucleation but not sufficient for three-dimensional nucleation, then only a small number of nuclei will form and these will act as substrates for further growth resulting in a small number of large crystals. These are the conditions that one tries to achieve in the laboratory for the growth of synthetic gemstones, semiconductors, laser rods, and other single crystal materials. Single crystals in the cave environment are what the ontogeny scheme labels first order individuals and these are taken up first.

\section{FIRST ORDER INDIVIDUALS: THE CRYSTAL GROWTH OF CALCITE}

Because it is transported and recrystallized limestone, calcite is the dominant mineral in caves making up on the order of $80-95 \%$ of speleothem volume. However, calcite precipitation appears in many other situations in nature and in technology. Calcite, as single crystals of Iceland spar, is an important optical material. Calcite is an important feedstock in the chemical industry and is a component of many commercial products. Precipitated calcite forms boiler scale and clogs pipes, and calcite (and aragonite) makes up the shells of many organisms. Calcite, aragonite, and dolomite make up the bulk of marine sediments so there is a very large literature on the precipitation of these minerals from seawater (Morse et al., 2007). Leaving aside seawater issues, there remains a huge literature, much too large to completely review here, on calcite precipitation in fresh water reactions.

The precipitation and crystal growth of calcite is one of the most complex and paradoxical systems ever studied. A crystal-grower's rule-of-thumb is that if a substance occurs widely in nature in the form of large mineral crystals, the substance will be relatively

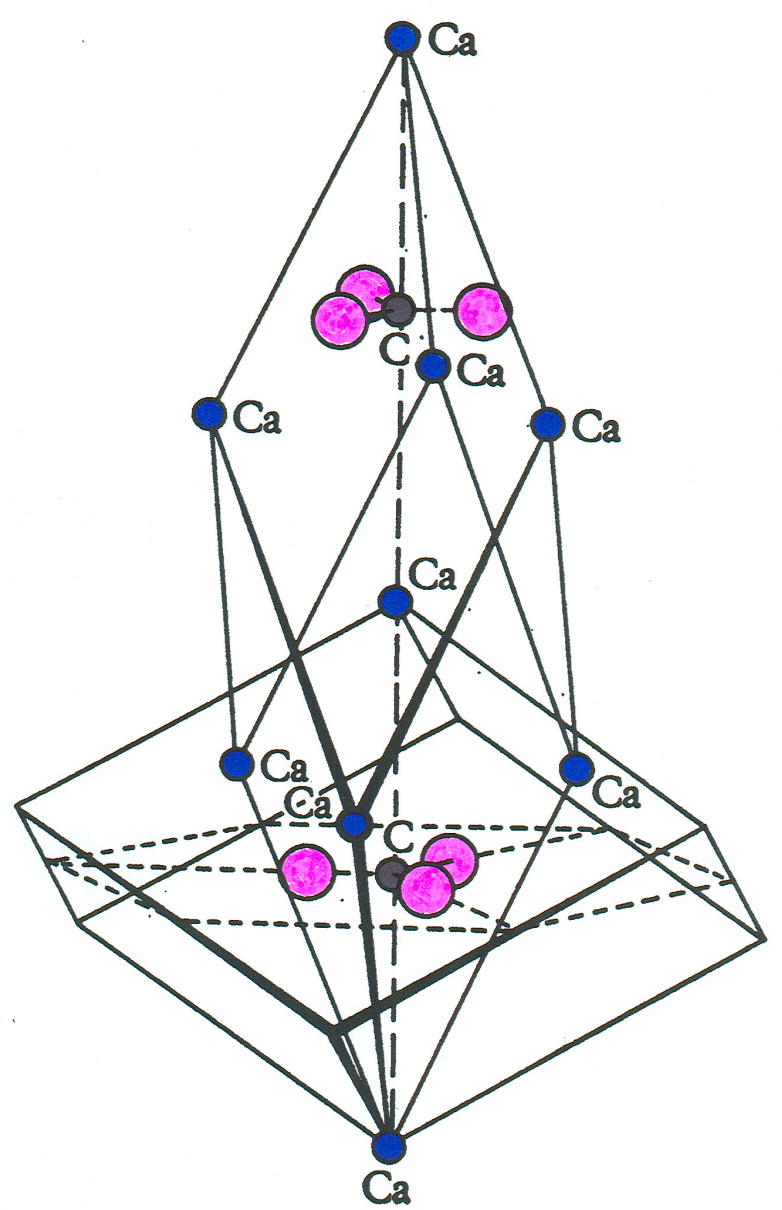

Fig. 5. The trigonal unit cell for calcite showing the layered structure perpendicular to the c-axis. The cleavage rhombohedron is drawn at the bottom.

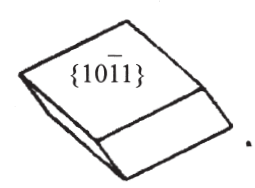

(a) Basic cleavage rhomb

(c) Modified rhombohedron (Nailhead spar)

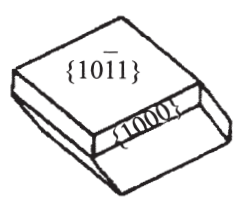

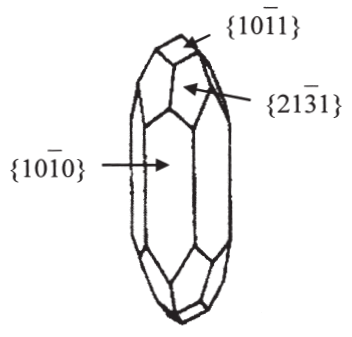

(b) Prismatic habit

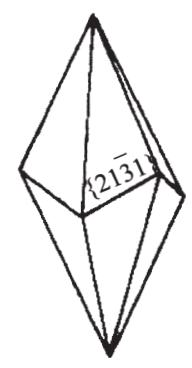

(d) Scalenohedron

(dog-tooth spar)
Fig. 6. Sketches showing for calcite (a) the basic cleavage rhombohedron; (b) the prismatic habit; (c) the modified rhombohedron and (d) the scalenohedron. The labeling of the faces is with respect to the hexagonal (non-primitive) unit cell. The crystallographic c-axis is vertical for all sketches. 


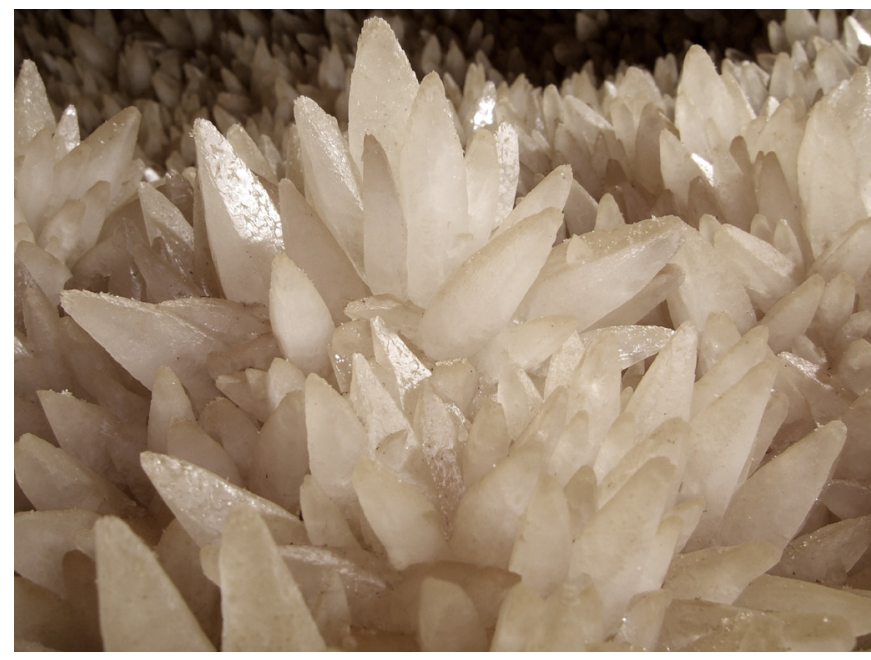

Fig. 7. Scalenohedral calcite in Helictite Cave, Burnsville Cove, Virginia (Photo by Philip C. Lucas; Used with permission).

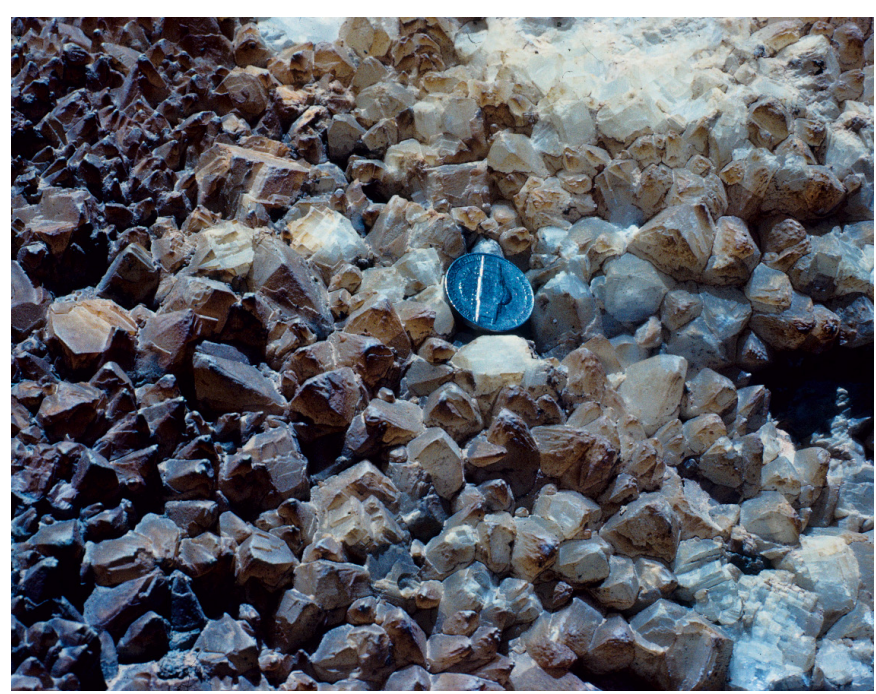

Fig. 8. Mixture of calcite crystal habits in a solution cavity in the Mississippian Pahasapa Limestone, Black Hills, South Dakota (Photo by the author).

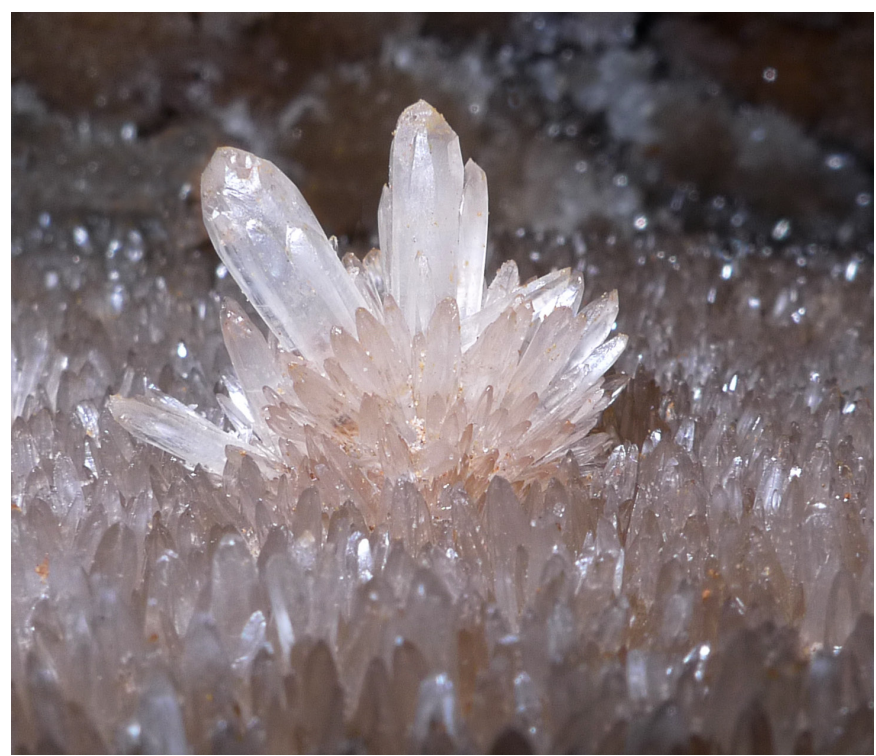

Fig. 9. Cluster of prismatic calcite crystals in a dry pool lining of scalenohedral calcite, Wishing Well Cave, Burnsville Cove, Virginia (Photo by Philip C. Lucas; Used with permission). easy to grow in the laboratory. Quartz is an excellent example of this guideline where the large hydrothermal crystals found in nature are duplicated on an industrial scale for the electronics industry. Calcite occurs in large, well-developed crystals as cold-water-deposited speleothems, as vug and vein fillings in limestone, as hydrothermal calcites associated with many ore deposits, in metamorphic rocks, and as the product of magmatic liquids in carbonatite rocks. In spite of this, optical grade calcite has not been grown in the laboratory. Hydrothermal fluids rich in $\mathrm{CO}_{2}$ or containing high concentrations of alkali carbonates can be used as solvents for the growth of small calcite rhombohedra (Balascio \& White, 1972) and there has been some success at calcite growth from high temperature fluxes. Reproduction in the laboratory of calcite crystals of the size seen in many cave deposits has never been achieved.

\section{The crystal structure of calcite}

The unit cells of calcite, dolomite, and other minerals with calcite-type structures have been refined several times (Effenberger et al., 1981; Reeder, 1983) but the structure determined by Bragg in 1914 remains basically correct. Calcite is rhombohedral (trigonal), space group $\mathrm{R} \overline{3} \mathrm{c}$. The trigonal unit cell (Fig. 5) contains 2 formula units of $\mathrm{CaCO}_{3}$. The structure is often drawn as a hexagonal cell with 6 formula units per cell and this is the cell used to write Miller indices for directions and faces. Calcite has a perfect $\{10 \overline{1} 1\}$ cleavage which allows calcite crystals to be broken into rhombohedral fragments. The rhombohedral cleavage fragments, as shown on Fig. 5, do not correspond to the unit cell. The crystallographic c-axis which is also the axis of 3-fold symmetry is the vertical axis of Fig. 5.

The calcite structure consists of alternating layers of $\mathrm{Ca}^{2+}$ ions and triangular $\mathrm{CO}_{3}{ }^{2-}$ ions. The carbonate ions have perfect 3 -fold symmetry. The $\mathrm{Ca}^{2+}$ ions are surrounded by six oxygen ions forming trigonally distorted octahedra. The structure of dolomite is almost identical to that of calcite except that $\mathrm{Ca}^{2+}$ ions and $\mathrm{Mg}^{2+}$ ions are placed in alternating layers. The energy barrier to placing $\mathrm{Ca}$ and $\mathrm{Mg}$ in neatly ordered alternating layers is the primary reason that dolomite rarely appears as a primary precipitate from aqueous solution and thus rarely occurs in speleothems. The cation arrangement reduces the space group symmetry of dolomite to $\mathrm{R} \overline{3}$.

Three of the many habits of calcite, along with a sketch of the basic cleavage rhomb are show in Fig. 6. Very common for calcite that has grown in cave pools is the scalenohedron (Fig. 7). Masses of calcite crystals that have likely grown from hot solutions take a more complex pattern which includes some scalenohedra (dog-tooth spar) but also some modified rhombohedra (nailhead spar) (Fig. 8). Calcite with a prismatic habit is not common in caves but one very nice example was discovered in the Wishing Well Cave in Burnsville Cove, Virginia (Fig. 9).

\section{Subindividuals: the domain structure of calcite}

The hierarchy of speleothem ontogeny proposed by Self \& Hill (2003) allowed for "subindividuals" at the zero level to account for the mosaic pattern found in many crystals. Single crystals, calcite included, are 
made up of small blocks - mostly called "domains" - that are slightly out of register with each other. This phenomenon was first noted by A.H. Compton (1917) in early studies of X-ray diffraction and was later found to be a near-universal pattern in what are otherwise perfect single crystals. The domain mismatch for calcite is $8.5 \times 10^{-5}$ radians or $0.03^{\circ}$. The hierarchy of mineral ontogeny (Table 1) also allows for a second order individual called a "block crystal". Block crystals (see Fig. 14 in Self \& Hill, 2003) appear to be nothing more than single crystals in which the domain mismatch is somewhat larger than in typical crystals. Deciding when a domain boundary becomes a grain boundary and when a single crystal with a domain structure becomes polycrystalline depends on the properties of interest. The domain concept becomes particularly important when magnetic and electric properties of crystals are of concern (Newnham, 1974).

\section{Calcite growth rates from bulk solution measurements}

There is a very large literature on the bulk crystallization kinetics of calcite. The usual experimental setup is a reservoir of solution from which calcite can be precipitated by spontaneous nucleation or by seeded growth. Experimental variables include degree of supersaturation, temperature, $\mathrm{pH}, \mathrm{CO}_{2}$ pressure, ionic strength, and the presence of specific other ions whose influence on the growth process is being investigated. In addition to the simple reservoir and the many chemical variables, experiments can be set up to maintain constant $\mathrm{pH}$, constant supersaturation, and to investigate the effects of fluid flow with various stirring and flow-through arrangements. These bulk experiments have relatively less application to the interpretation of calcite growth in cave environments and so only a few typical results are summarized here.

Most of the experiments use seeded growth so that the measurement is of the growth rate of preexisting calcite nuclei. These, in turn, can be divided into experiments in which calcite is precipitated by the reaction of soluble salts such as $\mathrm{Na}_{2} \mathrm{CO}_{3}$ or $\mathrm{K}_{2} \mathrm{CO}_{3}$ and $\mathrm{CaCl}_{2}$ or $\mathrm{Ca}\left(\mathrm{NO}_{3}\right)_{2}$ and experiments where calcite is precipitated from supersaturated calcium bicarbonate solutions.

Measurement of rates determined by calcite precipitation from soluble salts (Reddy \& Nancollas, 1971; Nancollas \& Reddy, 1971; Wiechers et al., 1975; Meyer, 1979; Reddy \& Gaillard, 1981; Kazmierczak et al., 1982; Christoffersen \& Christoffersen, 1990) support a rate equation of the form given in equation (10) although there are some variations between authors.

$$
R=k S\left(\left[\mathrm{Ca}^{2+}\right]\left[\mathrm{CO}_{3}^{2-}\right]-\frac{K_{C}}{\gamma^{2}}\right)
$$

$\mathrm{R}$ is the rate of calcite growth, $\mathrm{k}$ is a rate constant, $\mathrm{S}$ is the surface area of the seeds, and the quantities in brackets are concentrations. $\mathrm{K}_{\mathrm{C}}$ is the solubility product constant for calcite, and $\gamma$ is the activity coefficient of the divalent cation. In effect, the rate is proportional to the surface area of pre-existing calcite particles and proportional to the supersaturation defined by the ion activity product.

Homogeneous nucleation of calcite from the reaction of $\mathrm{CaCl}_{2}$ with alkali carbonates (Pokrovsky, 1998) gives results in reasonable agreement with classical nucleation theory. Pokrovsky found an induction period, $\tau$, that depends on the surface energy and supersaturation, largely independent of magnesium concentration and ionic strength.

$$
\log \tau=C+\frac{2 \beta E_{S}^{3} V_{M}^{2}}{5\left(k_{B} T \ln 10 \log \Omega\right)^{2}}
$$

$\mathrm{C}$ is a fitting parameter, $\beta$ is a shape factor $(16.76$ for spherical nuclei), and other symbols as defined for equation (8). Fitting the measured induction times to the controlled supersaturation gave surface energies for calcite in the range of $60-67 \mathrm{~mJ} \mathrm{~m}^{-2}$ in agreement with literature.

Determination of calcite precipitation rates within the more relevant $\mathrm{CaCO}_{3}-\mathrm{CO}_{2}-\mathrm{H}_{2} \mathrm{O}$ system gives chemical variables such as $\mathrm{pH}$ and $\mathrm{CO}_{2}$ pressure more significance. House (1981) fitted his data to the Davies-Jones equation, similar in form to the Nancollas-Reddy equation (equation 10). Likewise the data from experiments on the heterogeneous nucleation of calcite on glass could be fitted to the Davies-Jones equation (House \& Tutton, 1982). The seeded growth data of Reddy et al. (1981) (Fig. 10) were collected at several $\mathrm{CO}_{2}$ concentrations but show clearly that supersaturation is the most important variable. However, the dependence of growth rate on other variables appears in the scatter in the points plotted in Fig. 10. A saturation ratio between 1.2 and 1.8 is needed to initiate the growth of calcite on pre-existing seeds. Reddy et al. (1981) fitted their data to a precipitation rate equation derived from the well-known PlummerWigley-Parkhurst equation for calcite dissolution that has been widely used for the interpretation of cave and karst development (Plummer et al., 1978). Because this equation contains expressions for both forward and backward rates, it can be applied to either dissolution or precipitation. Inskeep \& Bloom (1985) used still another data set to compare the various proposed rate equations and came to the conclusion that the Nancollas-Reddy equation worked about the best of any of them. The best fit was to a completely empirical rate equation

$$
R=k S(\Omega-1)^{n}
$$

Their data gave a best fit of $n=1.02$. For the ideal value of $n=1$, the Nancollas-Reddy equation can be derived from the empirical one.

What is being determined in all of the experiments described above are mass transfer rates - that is the rate at which material is transferred from the solution to the enlarging mass of small crystals. Mass transfer rate calculations can be applied directly to the deposition of additional calcite on existing speleothems. In this case, deposition is from a thin layer of water bathing the speleothem so that rates can be calculated either as mass transfer per unit area, or size increase in the speleothem. Early calculations (Dreybrodt, 1980, 1981; Buhmann \& Dreybrodt, 1985) used the Nancollas-Reddy equation to model the data. Comparison of calculated rates using the Plummer-Wigley-Parkhurst equation with actual growth rates in a travertine-depositing stream produced good agreement (Dreybrodt et al., 1992). After many investigations, the rate equation for the growth of calcite speleothems, particularly 


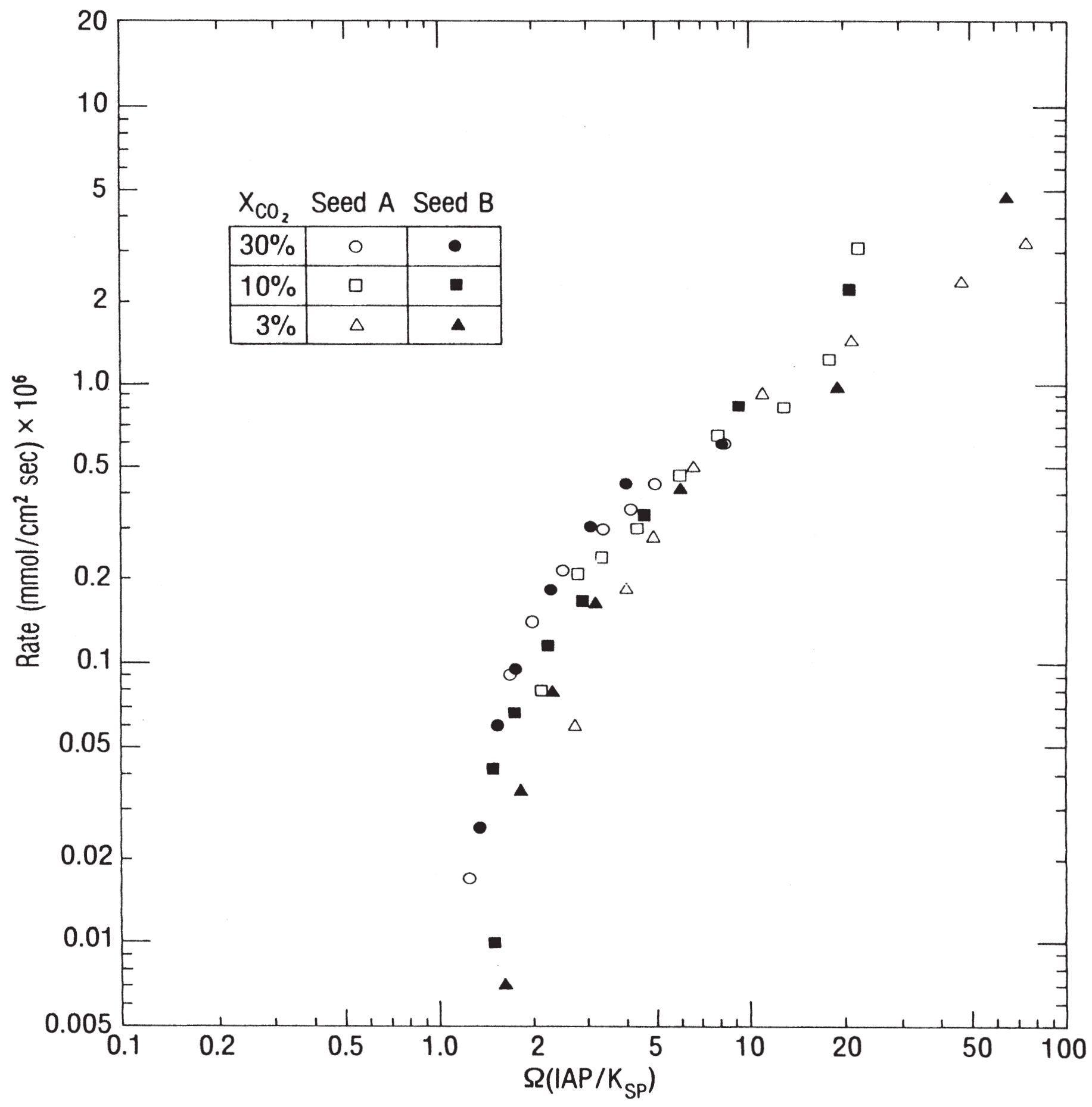

Figure 10. Growth rate of calcite on calcite seeds as a function of supersaturation. From Redddy et al. (1981).

stalagmites, is presented in the form (Dreybrodt, 1999): $R_{1}=\alpha\left(C-C_{0}\right)$ or alternatively $R_{2}=\beta\left(C-C_{0}\right)(13)$ $\mathrm{R}_{1}$ is the deposition rate in moles $\mathrm{cm}^{-2} \mathrm{~s}^{-1} ; \mathrm{R}_{2}$ is the growth rate of a stalagmite in $\mathrm{cm} \mathrm{yr}^{-1}$. The rate constants $\mathrm{a}$ and $\beta$ are related by $\mathrm{a}=8.5 \times 10^{-4} \beta . \mathrm{C}$ is solution concentration in $\mathrm{mmol} \mathrm{L}^{-1}$ and $\mathrm{C}_{0}$ is the equilibrium concentration. These simple-appearing equations hide a complex dependence on various system variables (Fig. 11), where $\mathrm{C}_{0}$ depends on temperature, $\mathrm{CO}_{2}$ pressure, and ionic strength. The rate constant a in units of $\mathrm{cm} \mathrm{s}^{-1}$ and $\beta$ in units of $\mathrm{cm} \mathrm{mmol}^{-1} \mathrm{~L} \mathrm{yr}^{-1}$ are functions of temperature and also the flow dynamics and film thickness of the water moving over the stalagmite. Some numerical values are given in Table 1 of Dreybrodt (1999). A quantitative comparison of predicted growth rates and measured growth rates for stalagmites from three caves gave a reasonable agreement (Baker et al., 1998).

Addition of impurity substances to calcite growth experiments generally inhibits the growth rate although not all substances are equally effective. Meyer (1984) published a comparison of the effects of 36 substances, 12 anions - mostly phosphates, 14 cations - alkaline earth and transition metals, and 6 organics. Phosphates and the transition metal (iron group) cations were most effective at inhibiting calcite growth. Transition metal ions can substitute for $\mathrm{Ca}^{2+}$ in the calcite structure. $\mathrm{Mn}^{2+}$ produces a strong cathodoluminescence which can be used to produce images of the growth pattern within the crystal (Reeder et al., 1990). 


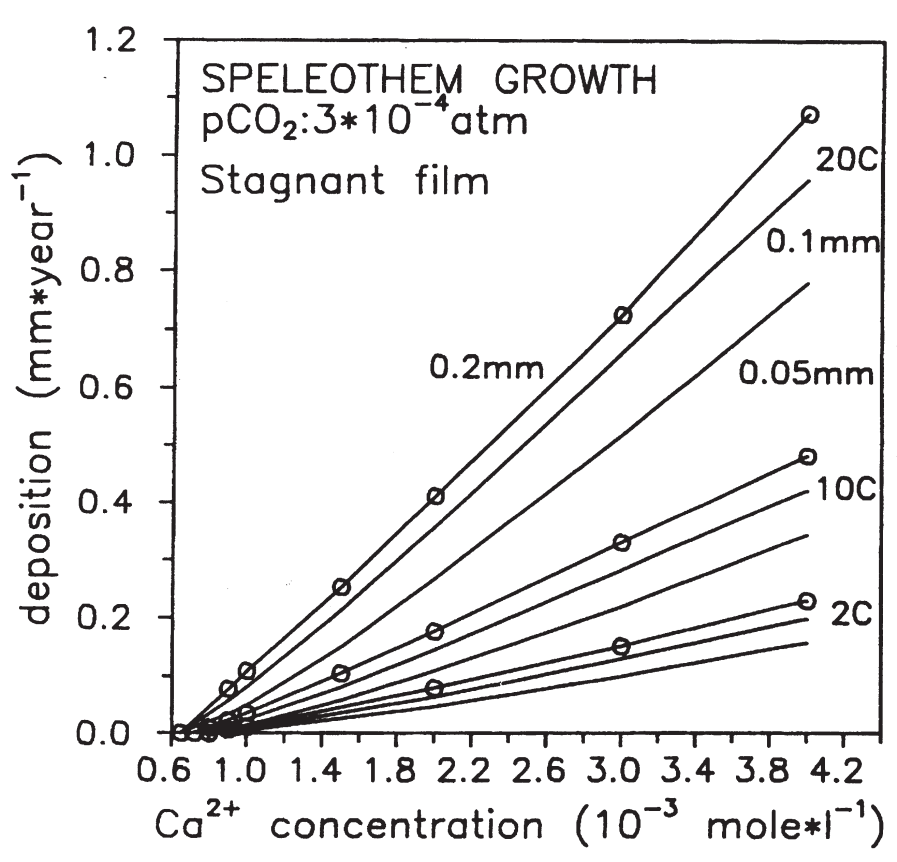

Fig. 11A (above) B (below). Calcite deposition from films of solution. (A) Stagnant film at several thicknesses and temperatures. (B) Turbulent films with a boundary layer thickness of $5 \times 10-3 \mathrm{~cm}$ (dashed lines) and $0.01 \mathrm{~cm}$ (solid lines). Numbers 1-4 and letters A-D refer to thickness of the water sheet of $0.1,1,10$, and $100 \mathrm{~cm}$ respectively. From Dreybrodt (1999).

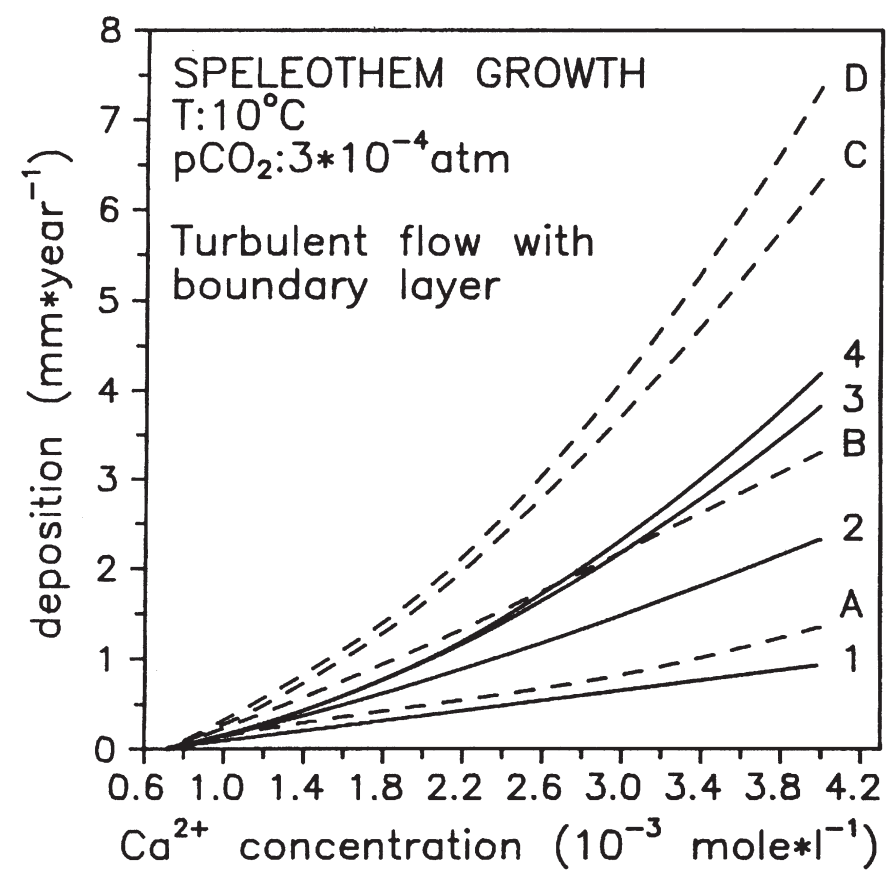

Of importance to the growth of speleothems and their ontogeny are the organic substances that are extracted from the overlying soils and carried into the underlying caves by vadose seepage waters. Humic substances (Inskeep \& Bloom, 1986) and dissolved organic carbon (DOC) (Lebrón \& Suárez, 1996, 1998) act to inhibit calcite growth. The effect of dissolved organic carbon does not seem to affect the critical supersaturation needed for calcite nucleation but it can decrease the precipitation rate by an order of magnitude (Fig. 12). The curve for the lowest concentration of DOC is close to the curve obtained without organics but at higher DOC concentrations, the precipitation rate falls rapidly. Investigations of alginate (a polysaccharide produced by bacteria and algae) show that it also inhibits calcite growth (Ma \& Feng, 2011; Lakshtanov et al., 2011). The proposed mechanism for alginate is that it coats the growth surface, effectively blocking the transport of ions to the surface.

\section{Nucleation and growth mechanisms of calcite}

It is apparent from the lack of agreement even about the basic rate equations, that bulk precipitation experiments with their many variables produce very limited insight into the mechanism of nucleation and growth of calcite. Although there was much better control of chemical purity of reactants, better accuracy in measurements, and improved understanding of the underlying thermodynamics and kinetics, the bulk growth experiments did not produce much of an advance over the investigations of the early $20^{\text {th }}$ Century when mineral ontogeny lost much of its appeal. The growth of calcite crystals takes place on the crystal surface where surface charge and the concentration of reacting species on the surface determine the processes. Real progress demands an understanding of the growth surface at the atomic level. Much attention over the past several decades has been focused determining the surface species, their interactions, and dependence on bulk solution parameters (Thompson \& Pownall, 1989; Stipp \& Hochella, 1991; Van Cappellen et al., 1993; Stipp, 1999; Nilsson \& Sternbeck, 1999; Perry et al., 2007)

New insight into the calcite nucleation process has been provided by molecular dynamics simulation (Cooke \& Elliott, 2007). Molecular dynamics calculations put atoms and molecules together subject only to a specific model of the interatomic forces using large computers to keep track of the mutual interactions of hundreds or thousands of atoms. Calcite nuclei formed in a vacuum were highly disordered with carbonate ions rotated out of their proper positions. When water was added to the simulation, well ordered calcite nuclei were formed.

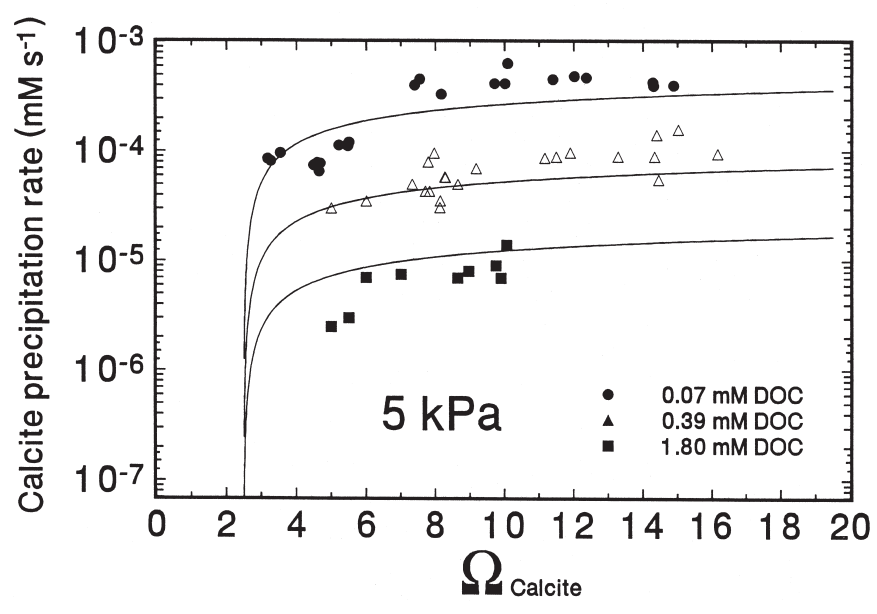

Fig. 12. Calcite precipitation rate in the presence of dissolved organic carbon (DOC). $\mathrm{CO}_{2}$ pressure $=5 \mathrm{kPa} ; \mathrm{T}=25^{\circ} \mathrm{C}$. From Lebrón and Suárez (1998). 

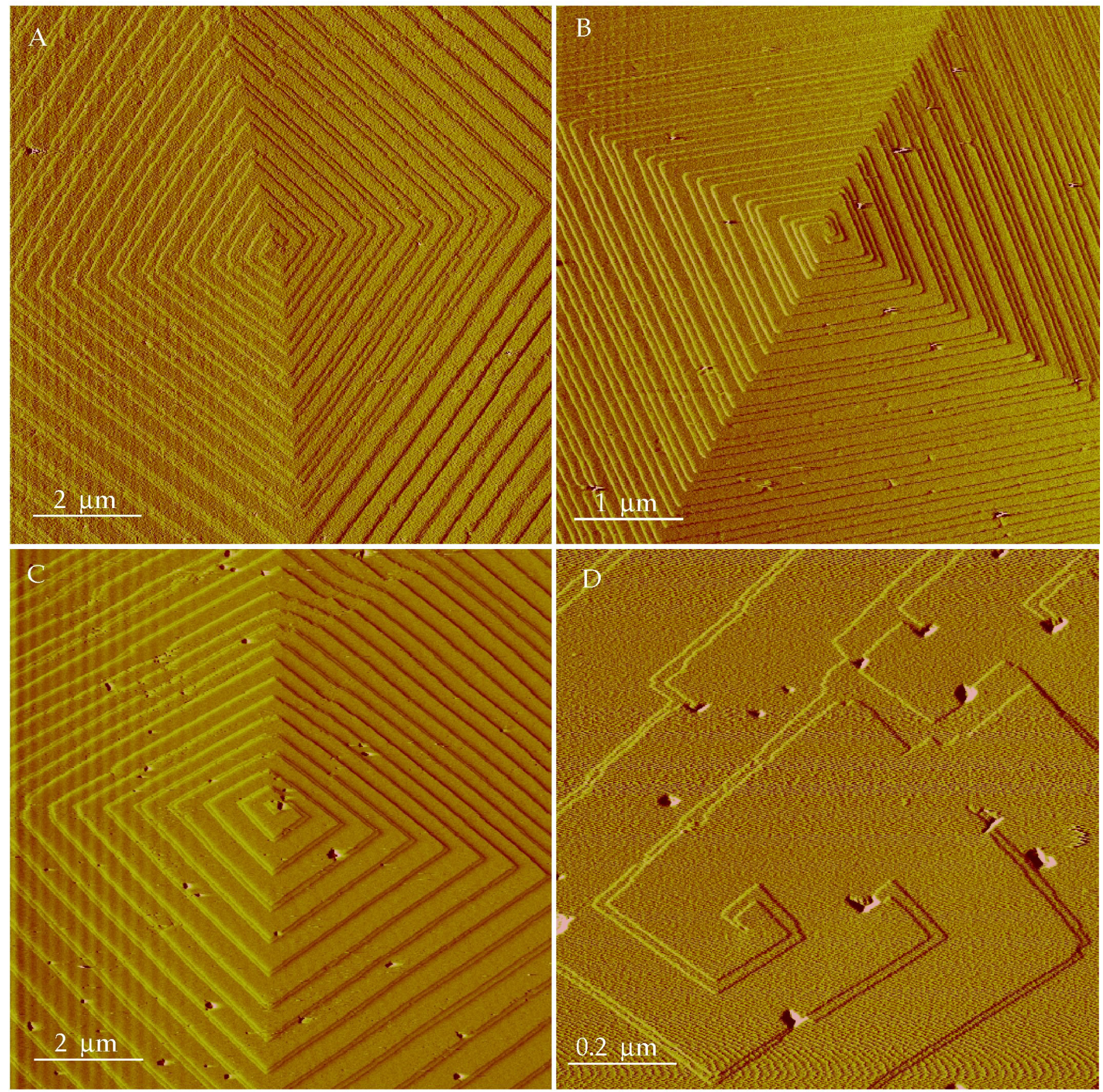

Fig. 13. AFM images of growth surfaces on $\{10 \overline{1} 4\}$ faces of calcite. From Teng et al. (2000); (images courtesy of P.M. Dove).

The most important invention for mineral ontogeny since X-ray diffraction and the scanning electron microscope is the atomic force microscope (AFM) (Ruiz-Agudo \& Putnis, 2012). Many of the contradictions and uncertainties discovered in the many studies of calcite precipitation can be resolved by examining the actual growth surface with the AFM. Etch pits and the evolution of the surface can be observed in a series of time-lapse images (Hillner et al., 1992). With a flow cell combined with the AFM, the details of the growth surface can be followed as the deposition reaction proceeds. The complexity of the growing calcite crystal can be seen in the AFM images of growth on the $\{10 \overline{1} 4\}$ cleavage face (Fig. 13) (Teng et al., 2000). Much calcite growth is on screw dislocations so that the growth pattern is a spiral. But depending on the atomic displacement along the dislocation (called the Burger's vector) there can be double spirals (Fig. 13A), triple spirals (Fig. 13B) and others. Growth by two-dimensional nucleation on an imperfection (heterogeneous two-dimensional nucleation) produces a hillock with a stepped (not spiral) pattern (Fig. 13C). Also apparent, in just this one series of images, are the complications introduced by crystal imperfections (Fig. 13D).

Likewise, the effect of supersaturation can be investigated (Fig. 14). Teng et al. (2000) use a slightly different definition of supersaturation than those given in equations (1-4). The supersaturations listed on Fig. 14 are defined as

$$
\sigma=\ln \frac{a_{C a} a_{C O_{3}}}{K_{C}}
$$




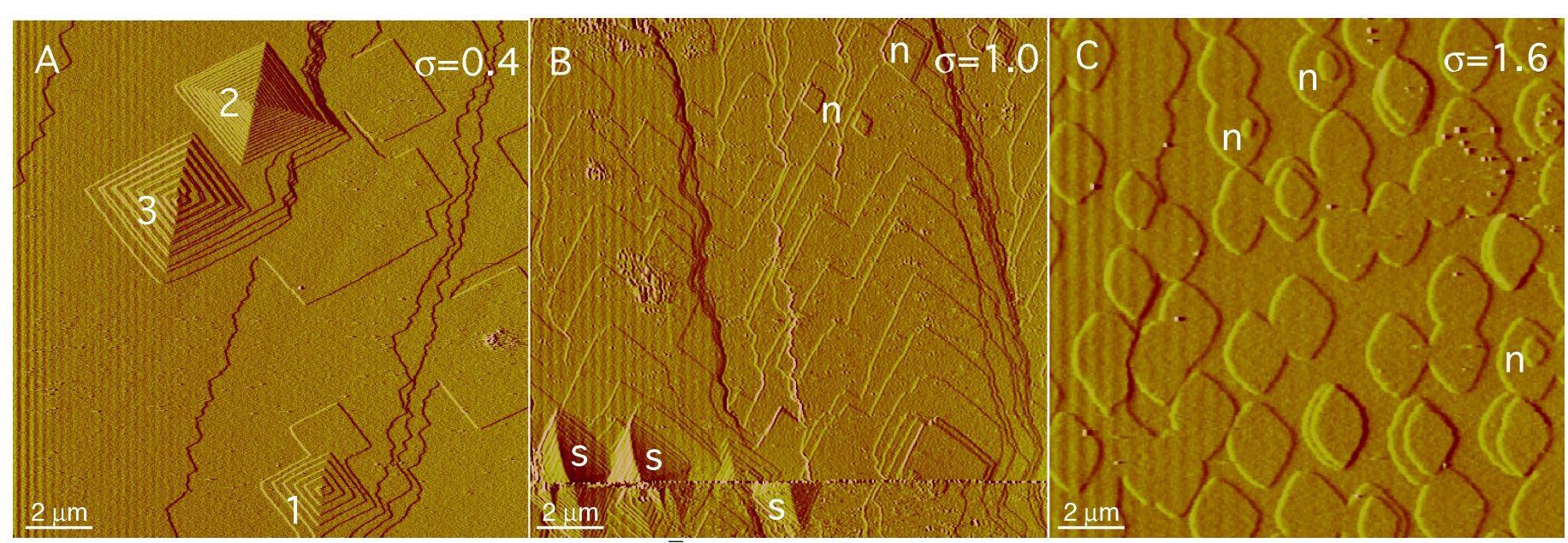

Fig. 14. Fluid cell AFM images of growth surfaces on a $\{10 \overline{1} 4\}$ face of calcite at different supersaturations. (a) Mainly spiral growth hillocks; (b) Regions of spiral growth, labeled s, and 2-dimensional nucleation and growth, labeled n; (c) Mainly 2-dimensional nucleation and growth. From Teng et al. (2000); (images courtesy of P.M. Dove).

At low supersaturation, growth is on screw dislocations resulting in hillocks with a spiral pattern. Increasing the supersaturation produces both growth on dislocations and growth by two-dimensional nucleation. At high supersaturation, two dimensional nuclei dominate the growth patttern. Bulk measurement of precipitation rates as a function of supersaturation would produce a rate curve that reflects a superposition of the two mechanisms. The AFM also can be used to determine the dependence of step-growth rate on the $\mathrm{Ca}^{2+} / \mathrm{CO}_{3}{ }^{2-}$ activity ratio (Larsen et al., 2010). From information on the growth details, it is possible to construct highly detailed models of the growth process (Wolthers et al., 2012).

Use of the AFM to examine the growth surface as layers of new atoms are being laid down provides considerable insight into the effect of impurities on crystal growth. $\mathrm{Mg}^{2+}$ is well known to inhibit calcite growth. AFM studies show that Mg decreases the step rate and thus the overall growth of the crystal (Fig. 15) (Davis et al., 2000). The proposed mechanism is that the incorporation of $\mathrm{Mg}^{2+}$ ions at the growing step increases the solubility, thus lowering the supersaturation at the step, and as a final result, lowering the growth rate. Further investigations reveal a more complicated role for $\mathrm{Mg}^{2+}$ showing that Mg-incorporation also disrupts the advancing step which also slows growth (Wasylenki et al., 2005a; Astilleros et al., 2010). The AFM also provides insight into the incorporation of $\mathrm{Sr}^{2+}$ (Wasylenki et al., 2005b), orthophosphate (Dove \& Hochella, 1993), and other trace elements (Paquette \& Reeder, 1995).

Most of the detailed studies of calcite precipitation have used the convenient $\{10 \overline{1} 4\}$ cleavage surface. However, explaining speleothem ontogeny requires an understanding of the controls on growth in many crystallographic directions. It appears that biomolecules are also effective in modifying calcite growth (Elhadj et al., 2006; Stephenson et al., 2008) Addition of organic molecules has been used to modify the external shape of calcite crystals (De Yoreo \& Dove, 2004). A variety of calcite crystal morphologies have been obtained using simple carboxylic acids (Henderson et al., 2008).

\section{Speleothems containing large organic molecules}

It is now generally recognized that the characteristic red/yellow/brown colors of calcite speleothems as well as their characteristic luminescence is due to humic and fulvic acids (White \& Brennan, 1989; Van Beynen et al., 2001). These substances are derived

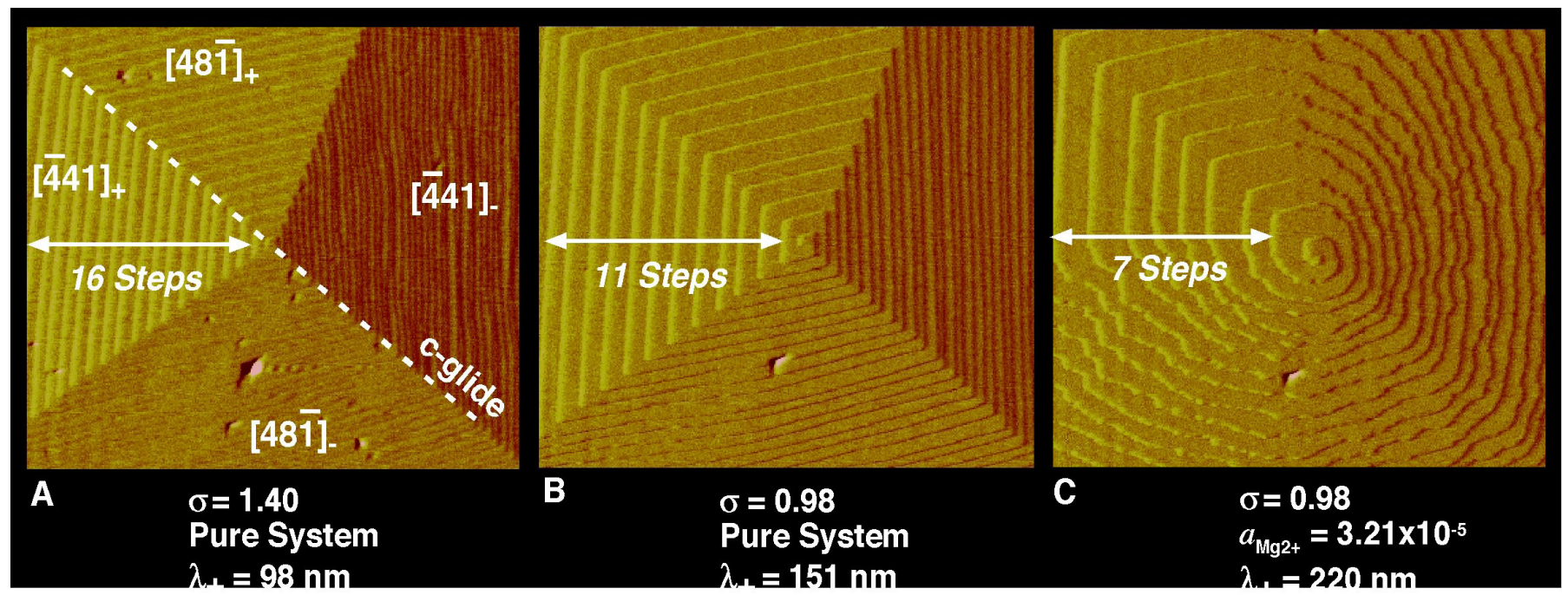

Fig. 15. AFM images of a calcite $\{10 \overline{1} 4\}$ surface showing the effects of supersaturation $(\sigma)$ and $\mathrm{Mg}^{2+}$ concentration. Decreasing supersaturation or increasing Mg result in wider step terraces. Images are 3 × $3.5 \mu \mathrm{m}$ with a step height of $3.1 \AA$. From Davis et al. (2000); (images courtesy of P.M. Dove). 


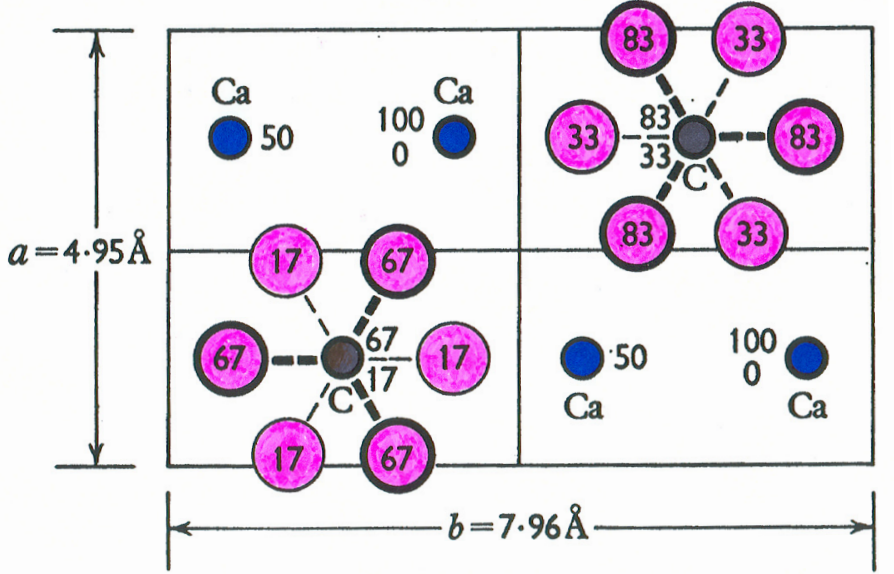

Fig. 16. The orthorhombic unit cell for aragonite drawn as a projection on the $a-b$ plane. The crystallographic c-axis is perpendicular to the plane. The numbers describe the fractional distance of the atoms (on a scale of 100) above the basal plane.

from overlying soils and are carried through the epikarst and vadose zones into the underlying caves by the same processes that carry the carbonate species into the cave. Humic and fulvic acids are good complexing agents. They are formed in the acidic environment of the upper part of the soil zone, which is generally well-leached of calcium ions. Maintenance of acidic conditions to the bedrock surface can result in transport of only the fulvic acid fraction and lightcolored, highly luminescent speleothems occur in the cave below. Rising $\mathrm{pH}$ near the bedrock interface or in soils trapped in the epikarst allows the humic component to be mobilized as well. Fulvic and humic acids have molecular weights in the range of 300 to thousands of daltons, yet are incorporated in large-grained calcite crystals as an integral part of the crystal structure. The organic colorants are not a grain-boundary staining. Both color and luminescence banding are continuous through centimeter-size crystals down to a resolution of at least a few micrometers. A study of the growth of calcite in agarose hydrogel (agarose is a large, linear polysaccharide) shows by electron tomography that the macromolecule was incorporat-

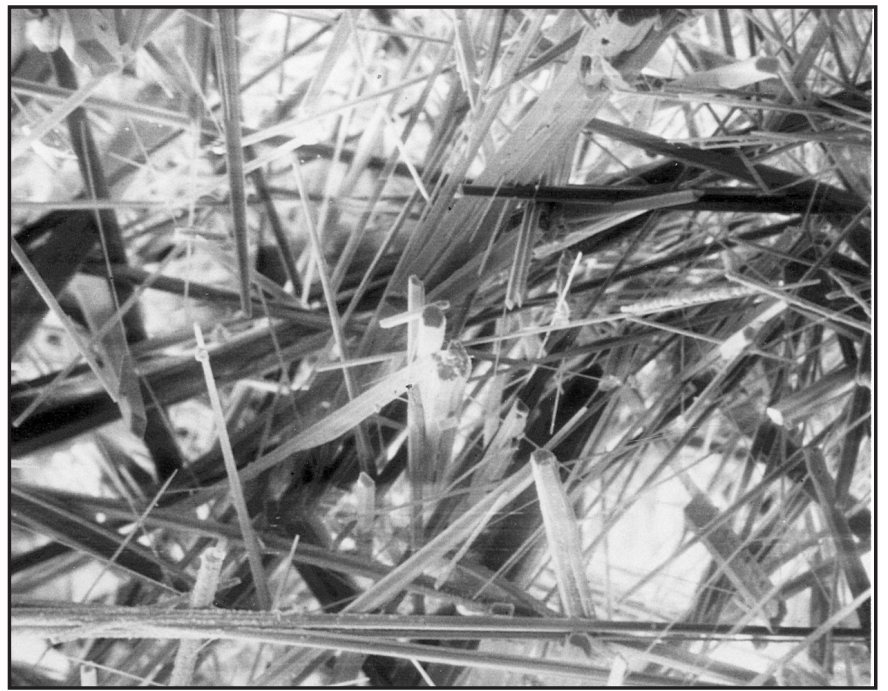

Fig. 17. SEM image of aragonite needles from a wall coating in Butler Cave, Virginia. Width of image about $1.5 \mathrm{~mm}$. The diameters of the needles are in the range of $10 \mu \mathrm{m}$. Note pseudo-hexagonal outline on broken needles. ed within the calcite structure without disruption (Li et al., 2009). There may be a similar inclusion of the large molecules of humic substances. Although humic substances are known to inhibit calcite growth (Inskeep \& Bloom, 1986), there is a possible role for these organic molecules to act as templates on which the growing calcite crystals are nucleated. Lowering activation barriers would permit cave calcites to grow at lower supersaturations and might help account for the observation that speleothems tend to be composed of a small number of large crystals.

\section{FIRST ORDER INDIVIDUALS: THE GROWTH OF ARAGONITE}

\section{The crystal structure of aragonite}

The aragonite structure was first determined by W.L. Bragg in 1924 and assigned to the orthorhombic system. The structure was refined by a number of authors in the 1970s (reviewed by Speer (1983). A new set of highly precise unit cell axes and atomic positions and their temperature dependence was recently published (Ye et al., 2012). The labeling of the crystal axes is arbitrary in the orthorhombic system but, of course, the internal arrangement of atoms and their symmetry operations are not. As a result, there are six possible space group symbols (but only one space group) depending on the choice of axis labeling. Different authors have made different choices resulting in possible confusion, particularly when describing fast growth directions for aragonite crystals. Bragg's original choice was Pcmn. What is now considered by crystallographers to be the standard setting for this space group is Pnma. Most of the recent refinements of the aragonite structure have used Pmcn and this is axis convention used in the structure drawing (Fig. 16). In addition, Bevan et al. (2002) have argued that the true symmetry of aragonite is triclinic, space group $\mathrm{P} \overline{1}$, or possibly $\mathrm{P} 1$ due to internal twinning on an atomic scale. The lower symmetry may play a role in the common appearance of aragonite in biogenic carbonates and by extension, possibly in speleothems.

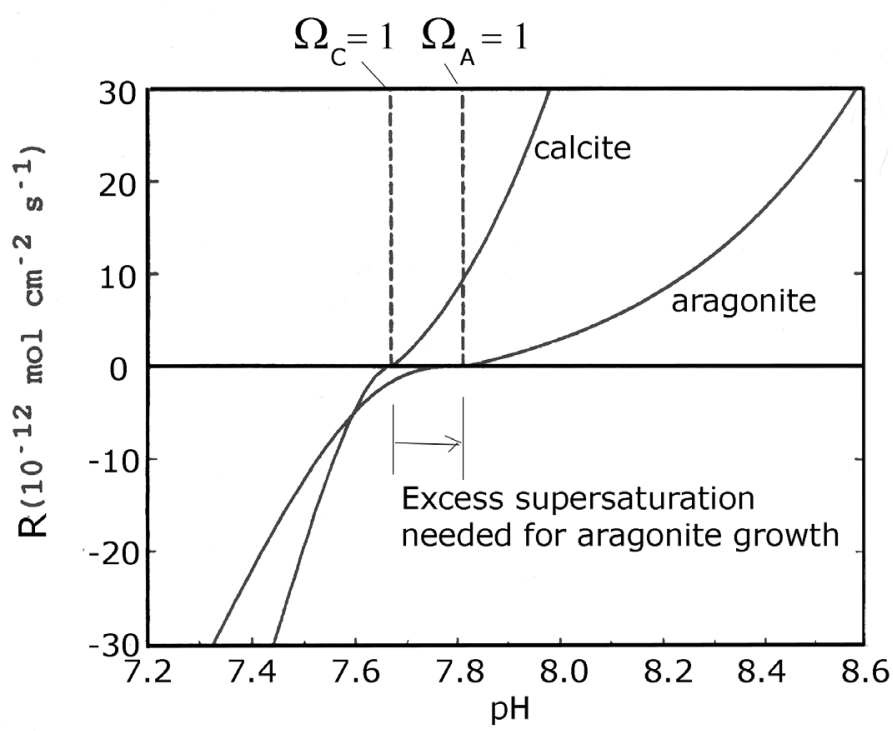

Fig. 18. Rate curves for the precipitation and dissolution of calcite and aragonite. Adapted from Gutjahr et al. (1996a). 
Like calcite, aragonite can be considered a layered structure with the layers perpendicular to the crystallographic $c$-axis. There are 4 formula units of $\mathrm{CaCO}_{3}$ in the primitive cell. If the cell is divided into quadrants, as shown in Fig. 16, two Ca-ions occupy the northwest and two the southeast quadrants, one on the bottom and top of the cell (for atoms on cell faces, only half of the atom is counted) and the other on the mid-plane of the cell. Two carbonate ions occupy each of the northeast and southwest quadrants, perpendicular to the c-axis. However, the ions are offset along the $c$-axis by the fraction of the $c$-axis shown in Fig. 16. In each quadrant, the top carbonate ion is rotated $60^{\circ}$ with respect to the one below it. In the lower symmetry of the aragonite cell, the carbonate ions are slightly distorted from their ideal 3-fold symmetry and are slightly puckered. In the aragonite structure, each $\mathrm{Ca}$-ion is surrounded by 9 oxygens, making aragonite somewhat more dense than calcite.

Although the structure is orthorhombic, a pseudo-hexagonal habit appears in many aragonite occurrences. The fast growth direction is [001] and this growth direction dominates others so that aragonite in speleothems is almost always in the form of long acicular or needle-like crystals (Fig. 17). Most synthetic preparations of aragonite also present the acicular habit (Ota et al., 1995; Westin and Rasmuson, 2005; Wang, 2008; Zhou et al., 2009)

\section{The growth of aragonite}

The homogeneous nucleation of calcite requires a substantial supersaturation (Figs. $10 \& 12$ ). The supersaturation for the homogeneous nucleation of aragonite seems to be lower but specific values were not discovered in this review. The literature on aragonite growth is much smaller than the literature on calcite growth but one comprehensive comparative study is helpful (Gutjahr et al., 1996a). These were seeded experiments using a $\mathrm{pH}$-stat arrangement so that the nucleation step was not a consideration. The super-

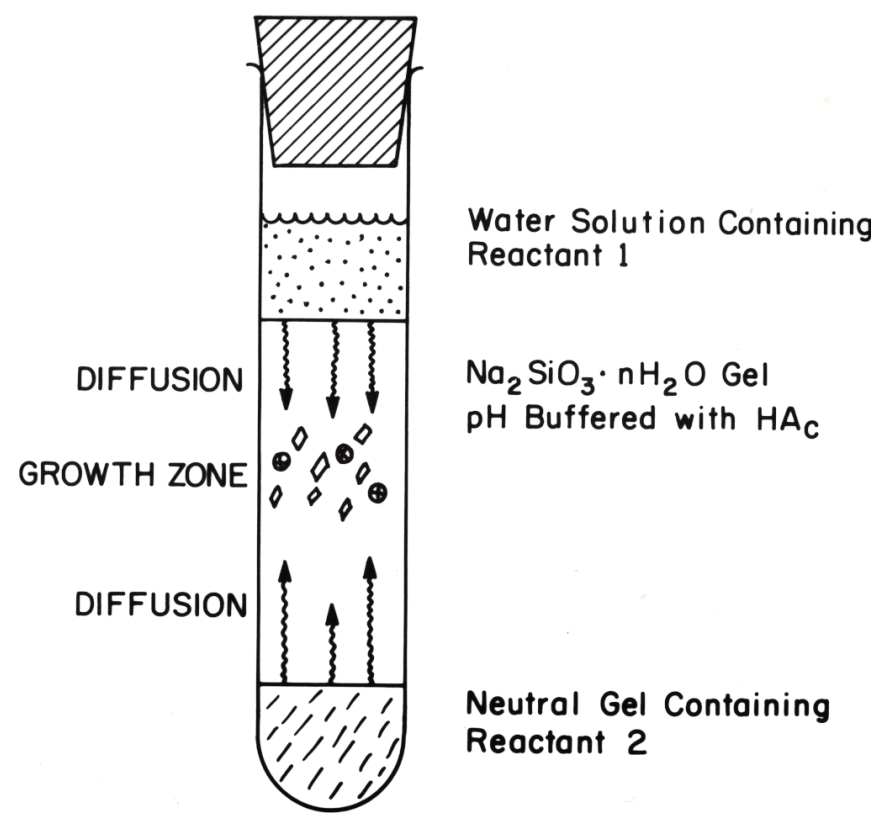

Fig. 19. Experimental set up for the growth of calcite crystals in gels. Adapted from McCauley and Roy (1974).

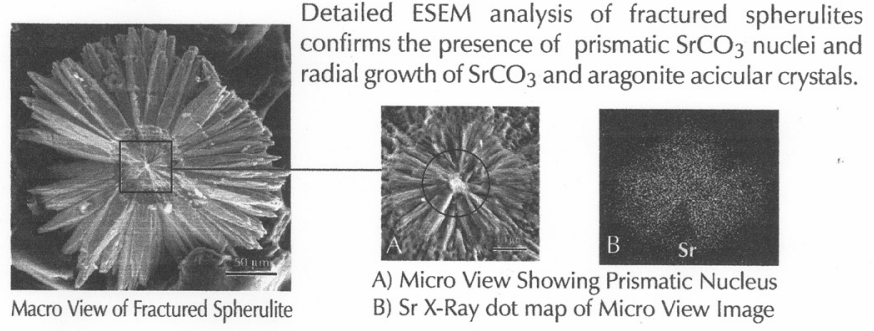

Fig. 20. Evidence for the existence of a Sr-rich nucleus in the growth of aragonite spherulite. Panel B shows the distribution of $\mathrm{Sr}$ in the crystal core shown in A. Panel provided courtesy of J.W. McCauley.

saturation was measured by the shift in $\mathrm{pH}$ from $\mathrm{pH}$ at equilibrium which has different values for calcite and aragonite.

$$
S=\Omega \cong \frac{\left[H^{+}\right]_{S}}{\left[H^{+}\right]}
$$

Supersaturation could be either positive or negative in these experiments so both precipitation and dissolution could be measured. Calcite seeds were used for calcite growth; aragonite seeds for aragonite growth. Aragonite grew on the aragonite seeds although the solutions were also supersaturated with respect to calcite. The comparison (Fig. 18) shows the offset in equilibrium saturation between calcite and aragonite. Aragonite requires a higher supersaturation to achieve a given rate of growth than does calcite. Curiously, the precipitation rates of calcite and aragonite have greater differences than do the dissolution rates.

\section{Nucleation and the aragonite/calcite problem}

There have been numerous measurements of the equilibrium phase boundary between calcite and aragonite as functions of temperature and pressure, some of which are summarized by White (1997). Although the measurements are not in perfect agreement, there is no doubt that aragonite is not thermodynamically stable at atmospheric pressure at any temperature above absolute zero. To stabilize aragonite at typical cave temperatures requires pressures in the range of $300-500 \mathrm{MPa}$ (3000 to 5000 atmospheres). Thermodynamics not withstanding, aragonite is a common speleothem mineral and also appears in many other low pressure environments. The search for an explanation has been called the "aragonite/calcite problem".

It has long been known that any of the three low pressure modifications of $\mathrm{CaCO}_{3}$ can be precipitated from calcium/carbonate solutions by adjusting the $\mathrm{Ca} /$ carbonate ratio, the $\mathrm{pH}$, and other solution parameters (e.g. Wray \& Daniels, 1957; for a review of the very early literature, see Curl, 1962). Two mechanisms have been identified. One is that some impurity will inhibit calcite nucleation so that the supersaturation builds up sufficiently to exceed the critical value for aragonite nucleation. The other is that aragonite grows epitaxially on a pre-existing nucleus that favors the aragonite structure. $\mathrm{Mg}^{2+}$ and $\mathrm{Sr}^{2+}$ have been proposed as the principal ions responsible for these two mechanisms respectively. 
The $\mathrm{Mg}^{2+}$ ion is known to inhibit calcite growth and was suggested by Berner (1975) as an important factor in promoting aragonite growth. The role of $\mathrm{Mg}^{2+}$ as an inhibitor of calcite growth was identified in the AFM experiments described above. It has also been shown that $\mathrm{Mg}^{2+}$ does not inhibit the growth of aragonite (Gutjahr et al., 1996b).

The rate of precipitation and growth of slightly soluble crystals can be studied by growing the crystals in neutral gels (Henisch, 1970) (Fig. 19). By allowing one reactant to diffuse into the gel from one side and the other reactant from the other side, transport rates are controlled and crystals grow to sufficient size to study both morphology and internal structure. A comprehensive study of the gel growth of calcite from $\mathrm{Na}_{2} \mathrm{CO}_{3}$ and $\mathrm{CaCl}_{2}$ solutions (McCauley \& Roy, 1974) showed that varying mixtures of calcite, aragonite, and vaterite could be produced by varying the reactant concentrations and the $\mathrm{pH}$. Many different crystal morphologies could also be obtained.

The role of strontium is thought to act by forming an early nucleus of $\mathrm{SrCO}_{3}$ or a $\mathrm{Sr}$-rich $\mathrm{CaCO}_{3}$. $\mathrm{SrCO}_{3}$ has the aragonite structure and would act as a template for the further metastable growth of aragonite.

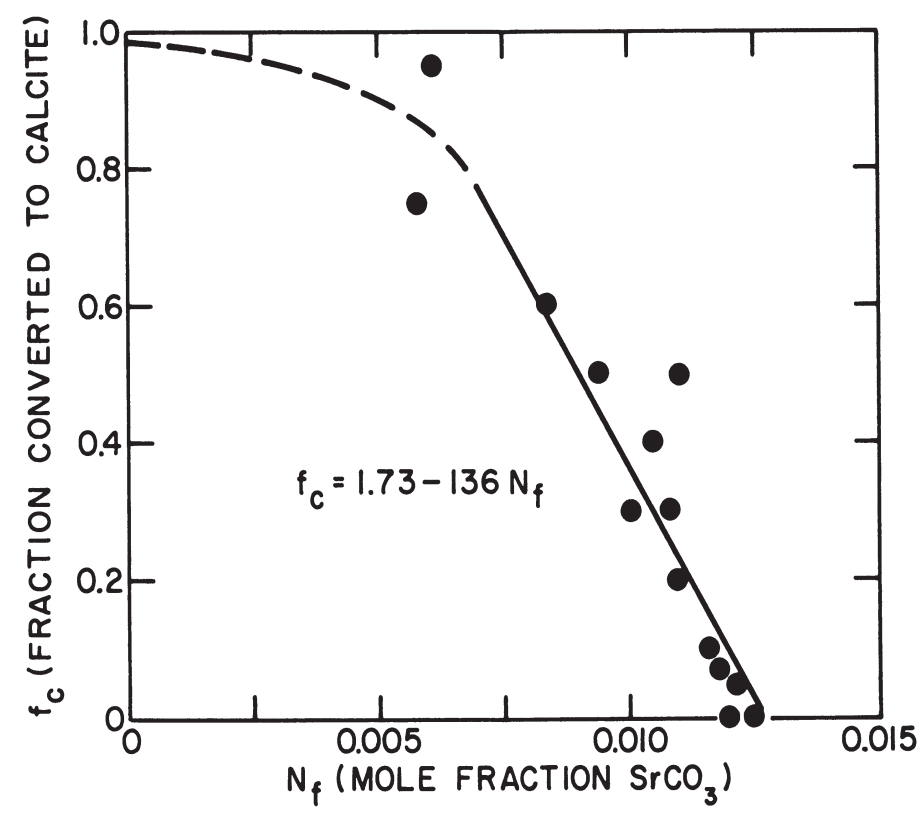

Fig. 21. Fractional conversion of aragonite to calcite in Pleistocene coral as a function of strontium content. Data from Siegel (1960); figure from White (1994).

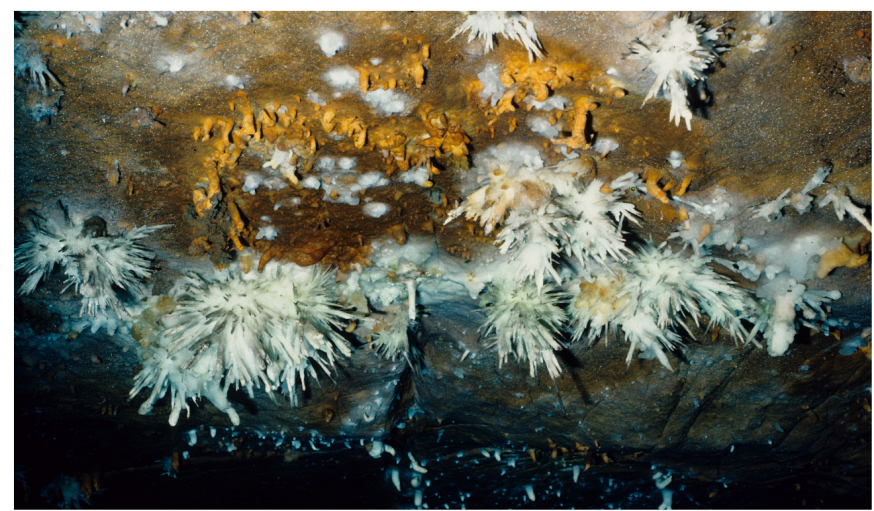

Fig. 22. The anthodites in Skyline Caverns, Virgina (Photo by the author).
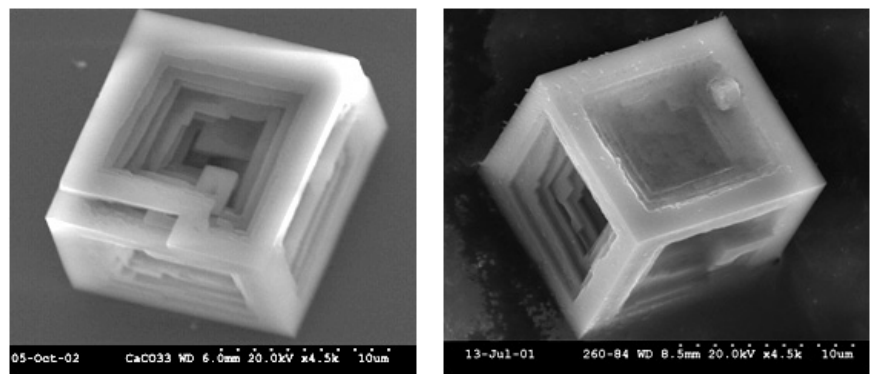

Fig. 23. A and B: Hopper crystals of calcite grown from octylamine/ water bilayers. Unpublished data of Jun Wang, James Adair and W.B. White.

The presence of a Sr-rich nucleus was demonstrated in aragonite spherulites grown from gels (Fig. 20).

\section{The aragonite $\rightarrow$ calcite inversion}

Because aragonite is a metastable phase under cave conditions, there is a thermodynamic driving force tending to convert aragonite into the stable form of calcite. The kinetics of the inversion reaction for the dry solid are extremely sluggish at cave temperature but increase exponentially with temperature so that the inversion can be measured on a laboratory time scale when temperatures reach $300-400{ }^{\circ} \mathrm{C}$. The high temperature reaction has been studied in some detail because of its importance to the study of metamorphic rocks (Brar \& Schloessin, 1979; Hacker et al., 1992; Liu \& Yund, 1993). The mechanism is one of solid state diffusion. The fraction of aragonite converted to calcite as a function of time at any given temperature can be fitted to an Avrami-type equation

$$
f_{C}=1-\exp \left(-k t^{n}\right)
$$

The Avrami equation plots as an S-shaped curve with a slow rise as calcite nuclei are formed followed by a steep middle section as conversion proceeds, and finally flattens out as the aragonite source material is consumed. By calculating the rate constant, $\mathrm{k}$, from high temperature experiments and using the Arrhenius equation to extrapolate to cave temperature, transformation times of billions of years are obtained. Dry aragonite will persist essentially forever

When water is present, a different mechanism becomes dominant, that of dissolution of the metastable (thus more soluble) aragonite and re-precipitation of the stable (and thus less soluble) calcite (Carlson, 1983; Ogino et al., 1990). This mechanism is much faster than solid state transformation and some of the laboratory investigations would give inversion times

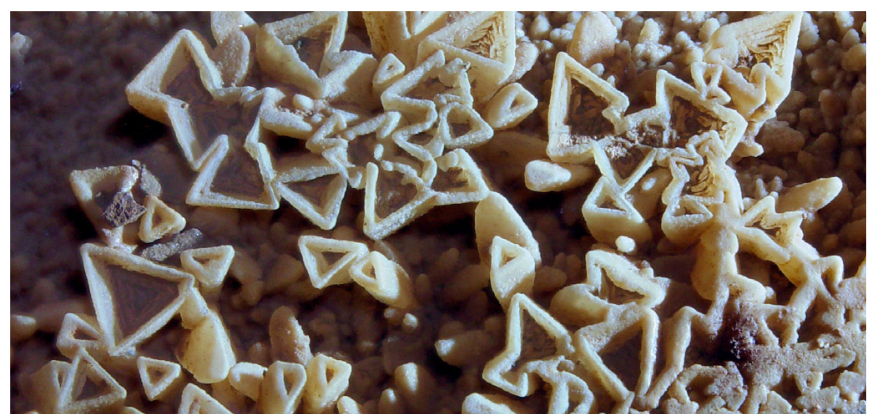

Fig. 24. Hopper crystals of calcite in Helictite Cave, Highland County, Virginia (Photo by Philip C. Lucas; Used with permission). 
of days rather than geologic time. Dissolution - reprecipitation reactions depend strongly on the surface of the original aragonite and on the chemistry of the water, particularly on the presence of impurities that might act to suppress the reaction. Because aragonite speleothems persist in the wet cave environment, some controlling factors must be present that blocks the rapid inversion to calcite. A study of recent marine sediments (Budd, 1988) gave inversion times of 4700 to 15,600 years in the fresh water zone and 8700 to 60,000 years in the mixing zone. $\mathrm{Sr}^{2+}$ is a likely candidate for the trace element blocking the inversion. Siegel (1960) analyzed a series of aragonite corals, ages only identified as "Pleistocene", for Sr-content and for fraction of conversion (Fig. 21). Corals with high strontium contents display less inversion to calcite.

The characteristic inversion times seem to be on the same order of magnitude as the age of many speleothems. From the perspective of speleothem ontogeny, one must expect microstructures produced by the primary precipitation of calcite and aragonite and also forms and microstructures resulting from inversion of aragonite to calcite. The anthodites in Skyline Caverns, Virginia, the type locality, have the external form of aragonite but much of the aragonite has converted to calcite (Fig. 22) (White, 1994). Cabrol et al. (1978) have identified a speleothem in which they claim that calcite has been inverted to aragonite.

\section{SECOND ORDER INDIVIDUALS OF CALCITE AND ARAGONITE}

Second order individuals are crystals that suffer from some defect in growth. The efforts of those growing crystals for technological application have been directed toward avoiding such crystals. However, in the process of avoiding them, much has been learned about why defective crystals form. Some of these growth distortions appear in calcite and aragonite; others are better displayed in gypsum.

\section{Skeletal crystals and hopper crystals}

In general, the corners of crystals grow the fastest, then the edges, and the slow growth directions are the faces. If impurities poison the growth of a set of faces, it is possible for the corners and edges to outgrow the faces resulting in the inverted structure known as a hopper crystal. Hopper growth is relatively common in laboratory-grown crystals and has been observed in the growth of calcite (Figs. 23A \& B). In this example, the external form of calcite has become almost cube-like.

Hopper crystals in caves are not common. In the example from Helictite Cave, Highland County, Virginia (Fig. 24), some unknown factor has completely shut down the fast [0001] growth direction leaving only a shell that retains the trigonal symmetry of the calcite crystal.

\section{Dendritic Growth and Split Crystals}

Dendrite crystals are tree-like forms with multiple branches. Dendrite crystals often form in crystal grown from the vapor. The most easily observed examples are frost crystals on windows in the winter. Dendrites are also common in metal crystals formed by cooling molten metal. The branches of dendrites oc-

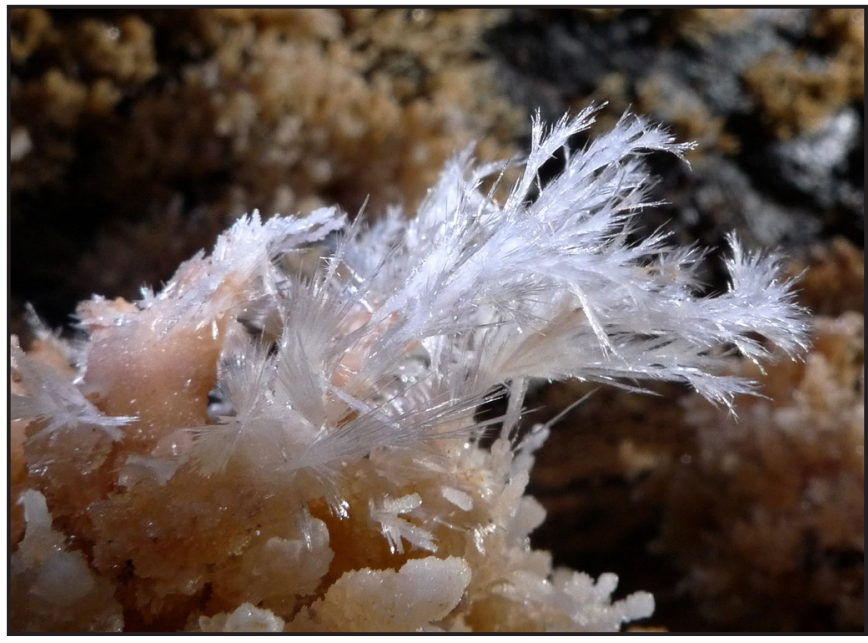

Fig. 25. Split crystals of aragonite from Wishing Well Cave, Highland County, Virginia (Photo by Philip C. Lucas). Used with Permission.

cur at fixed angles dictated by the underlying crystal structure. Because dendritic growth is very important to the properties of metals and alloys, dendritic growth mechanisms have been extensively investigated and a detailed theory for heat and mass transfer was developed 50 years ago (e.g. Bolling \& Tiller, 1960a,b). Dendrite growth was important in the technology of pulling germanium ribbons for semiconductors (Faust \& John, 1961) Dendritic growth is a runaway process in which the fast growth directions draw material from the melt, vapor, or solution thus lowering local supersaturation and suppressing growth in the slower growth directions. True dendrite growth does occur in caves but split crystals are more common.

Split crystals are rather more complex and may involve more than one mechanism. They are usually found in minerals with a tendency to acicular or fibrous growth. Split crystals begin with a single individual which separates into a sheaf of multiple branches as it grows. Unlike dendrites, there is usually no identifiable crystallographic relationship between the components. Consider the aragonite crystal shown in Fig. 25. Has this small speleothem formed from a few nuclei on the underlying crystalline substrate followed by multiple splitting of the growing crystal? Or were there multiple nucleation sites and the speleothem is composed of a sequence
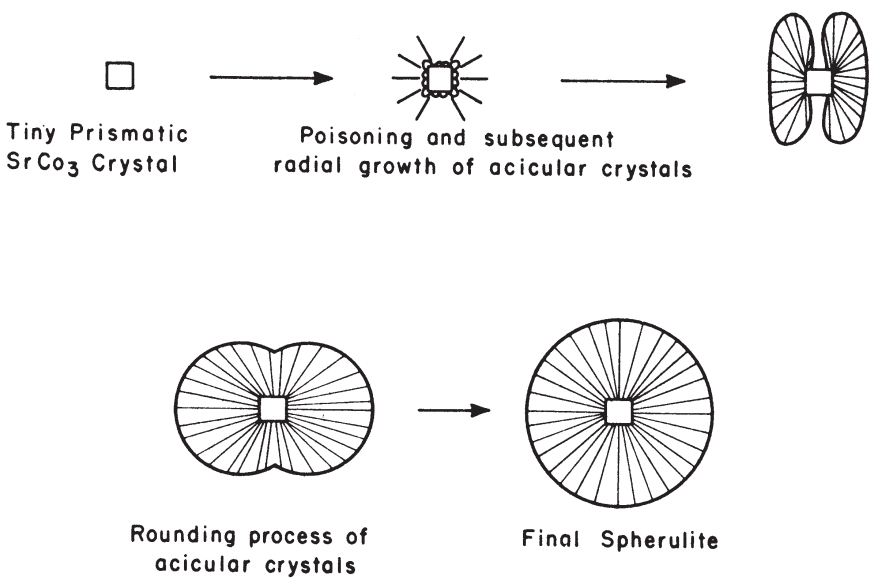

Fig. 26. The stages of growth of an aragonite spherulite. From McCauley \& Roy (1974). 


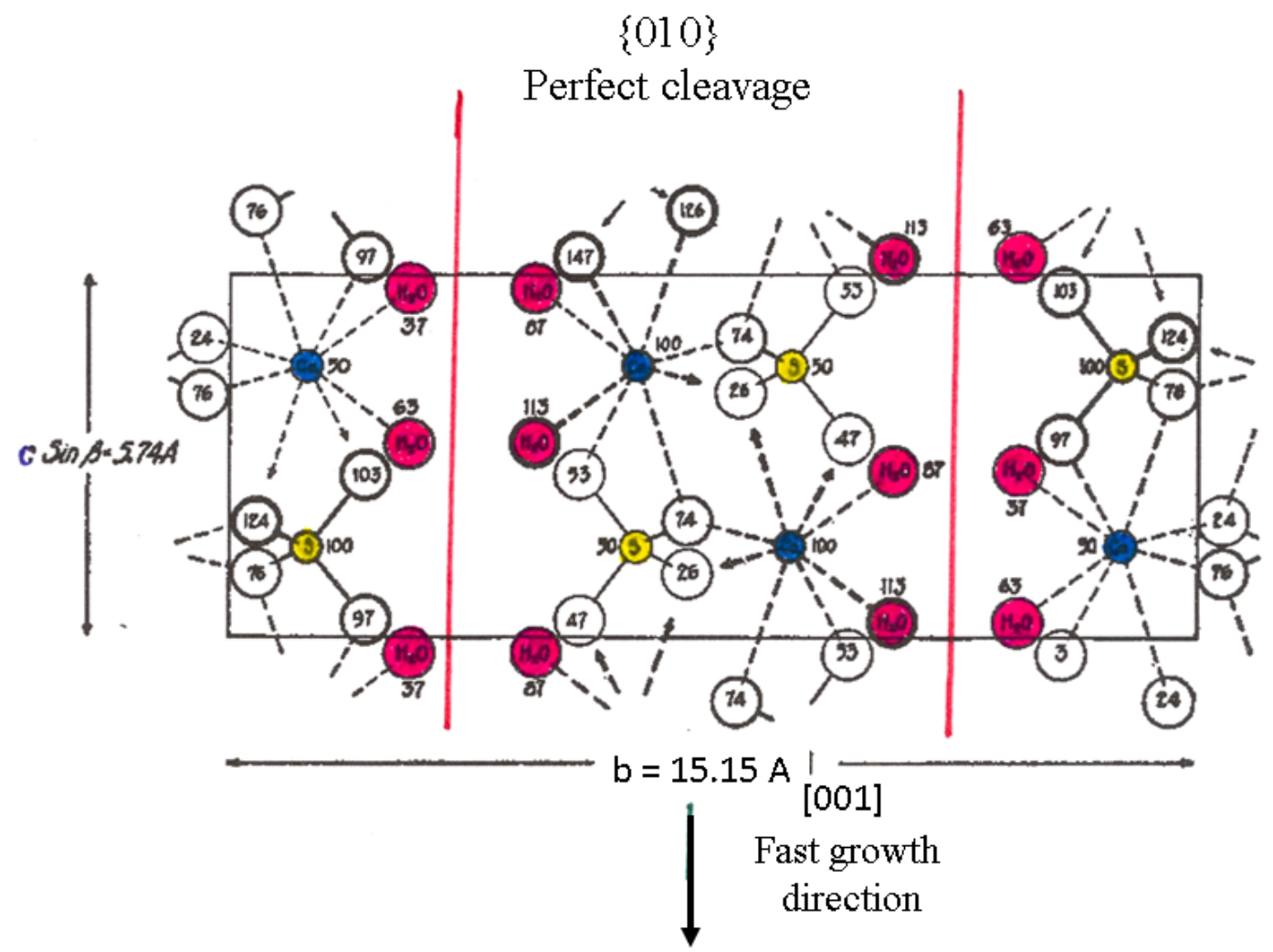

Fig. 27. The crystal structure of gypsum. The $\{010\}$ cleavage is indicated by the red vertical lines. The [001] fast growth direction is indicated by the arrow. of interrelated but individually nucleated crystals? Such questions might be answered by careful microscopic examination of the crystals but not by examination of only the external morphology.

\section{Spherulitic Growth}

Spherulitic growth of second order individuals produces roughly spherical objects composed of crystals that have grown radially from a single nucleus. Spherulitic growth requires a highly defective nucleus, the theory of which as set forth by Sears (1961) is based on the Cahn-Hilliard theory of nonclassical nucleation (Cahn \& Hilliard, 1959). The organizational scheme of mineral ontogeny (Table 1) provides separate names for spherulitic growth of somewhat different geometries although the underlying growth processes appear to be similar.

The spherulitic growth of aragonite in neutral silicate gel (McCauley \& Roy, 1974) proceeded at a rate that allowed the intermediate stages to be observed (Fig. 26). An initial nucleus was either defective or was poisoned by adsorption of impurities so that growth continued radially through stages until the final spherulite was achieved as shown in Fig. 20. Note that the Fig. 26 sketch suggests a highly ordered nucleus but the SEM image (Fig. 20) suggests that the real nucleus is irregular. A similar spherulitic growth sequence was observed for barium carbonate, which has the aragonite-type structure (García-Ruiz et al., 2009).

\section{THE CRYSTAL GROWTH OF GYPSUM: FIRST AND SECOND ORDER}

Gypsum speleothems almost always have a different external morphology and a different internal microstructure than calcite or aragonite speleothems. The external and internal forms reflect the growth mechanisms of gypsum. However, other cave minerals such as epsomite and mirabilite have growth mechanisms similar to gypsum. The precipitation of gypsum and anhydrite from seawater and other brines is the source of modern and ancient evaporite deposits. The minerals are found in many other environments and indeed may be important minerals on Mars. Gypsum is a component of the scales that clog desalinization plants. Processed gypsum is the principal component of the building material known variously as drywall, plasterboard, or sheetrock. As a result, the dissolution and reprecipitation of gypsum has received much attention.

\section{The crystal structure of gypsum}

Gypsum, $\mathrm{CaSO}_{4} \cdot 2 \mathrm{H}_{2} \mathrm{O}$, is monoclinic, space group I2/a (also cells constructed on A2/a and others) with four formula units in the unit cell. The structure was refined by X-ray diffraction (Cole \& Lancucki, 1974) to provide precise locations and interatomic distances for the calcium and sulfate ions. A refinement by neutron diffraction (Pedersen \& Semmingsen, 1982) provided accurate locations and orientations for the water molecules. The structure (Fig. 27) contains layers of $\mathrm{Ca}^{2+}$ and $\mathrm{SO}_{4}{ }^{2-}$ ions bounded by layers of water molecules. The $\{010\}$ planes that separate the layers of water molecules (indicated by red lines in Fig. 27) are bound only by the weak hydrogen bonds between the water molecules. This structural feature gives gypsum its perfect $\{010\}$ cleavage. Each $\mathrm{Ca}^{2+}$ ion is coordinated by six oxygen ions and two water molecules. The sulfate ions are distorted slightly from their ideal tetrahedral shape by the monoclinic symmetry. Gypsum appears to be a mosaic crystal with crystallite pairs intergrown at different angles (Follner et al., 2002). 


\section{Nucleation and growth of gypsum crystals}

The chemistry of gypsum growth is less complicated than carbonate growth because it essentially involves only the combination of $\mathrm{Ca}^{2+}$ ions and $\mathrm{SO}_{4}{ }^{2-}$ ions. The solubility of gypsum is about ten times that of calcite and aragonite. Because of the higher solubility, the growth of gypsum is on the borderline between surface reaction control which applies to lower solubility crystals such as calcite and aragonite and control by diffusion across fluid boundary layers which applies (usually) to more soluble crystals. The nucleation of gypsum appears to follow classical nucleation theory reasonably well (equations 8 and 9) (Keller et al.;, 1978). Nucleation rates were measured at four temperatures between 22 and $40{ }^{\circ} \mathrm{C}$. The size of the critical nuclei varied from 1.1 to $2.8 \mathrm{~nm}$ depending on temperature and method of calculation. A more detailed investigation of the nucleation process by high resolution transmission electron microscope (Van Driessche et al., 2012) suggests that the nucleation of gypsum requires an initial step in which nanocrystals of bassanite, $\mathrm{CaSO}_{4} \cdot 1 / 2 \mathrm{H}_{2} \mathrm{O}$, are precipitated first. These then aggregate to form bassanite nanorods (a few hundred $\mathrm{nm}$ in length), which then hydrate to form gypsum nuclei.

The growth of gypsum has been studied intensively but intercomparisons are difficult because of varying choices of rate equations and definitions of supersaturation. The rate of growth may be described by

$$
R=S k\left(\Omega^{1 / v}-1\right)^{n}
$$

$\mathrm{R}$ is the rate of growth in mol s $\mathrm{s}^{-1}, \mathrm{k}$ is a rate constant (temperature dependent) in $\mathrm{mol} \mathrm{s}^{-1} \mathrm{~m}^{-2}, \mathrm{~S}$ is the reactive surface area in $\mathrm{m}^{2}$, and $\Omega$ is the supersaturation, suitably defined. The exponents $v$ and $\mathrm{n}$ are to be determined by experiment. Some studies (Liu \& Nancollas, 1970; Witkamp et al., 1990; Zhang \& Nancollas, 1992) have found a parabolic rate law $(n=2)$ and from this deduced that the growth is by 2-dimensional nucleation. Another set of results (Van Rosmalen et al., 1981) argued for spiral growth and yet another Christoffersen et al., 1982) suggested that both mechanisms play a role. Microscopic examination of the growth surfaces (Bosbach \& Rammensee, 1994; Bosbach \& Hochella, 1996; Van Driessche et al., 2010) support the growth by buildup of layers by a 2-dimensional growth mechanism. All studies point to a surface reaction control rather than a diffusion-limited mass-transport control. The rate of growth is also strongly temperature dependent increasing exponentially with increasing temperature (Liu \& Nancollas, 1973).

Gypsum growth from a mixture of Dead Sea brines and seawater (Reznik et al., 2011) revealed an interesting and unexplained tenth order dependence of rate on supersaturation. A great range of supersaturations, fluid compositions, and ionic strengths could all be fitted to the rate equation

$$
R=S\left\{k_{1}\left(\Omega^{1 / 2}-1\right)^{10}+k_{2}\left(\Omega^{1 / 2}-1\right)^{2}\right\}
$$

The symbols have the same definition as in equation (17). Growth close to equilibrium follows the

parabolic rate law seen in many other investigations. At high supersaturations, the tenth-order process becomes important. The relevance of this discovery to gypsum growth in caves is that the highly watersoluble minerals epsomite and mirabilite are often associated with gypsum occurrences. For such occurrences, the seepage fluids that deposit the speleothems are likely of very high ionic strength.

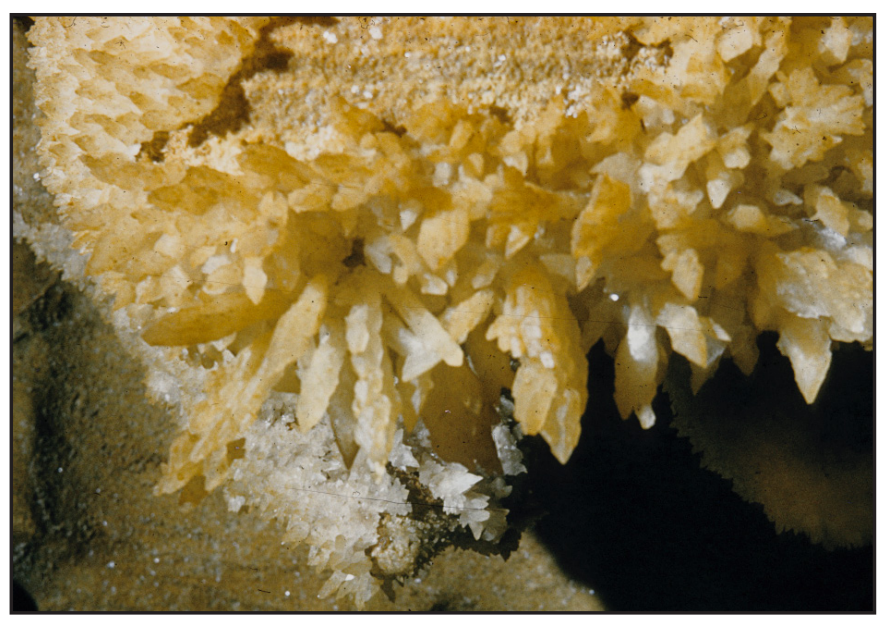

Fig. 28. Gypsum crystals coating a bedrock pendant in Cumberland Caverns, Tennessee. Now dry, these crystals apparently grew at a time when the pendant was immersed in a pool of water (Photo by the author).

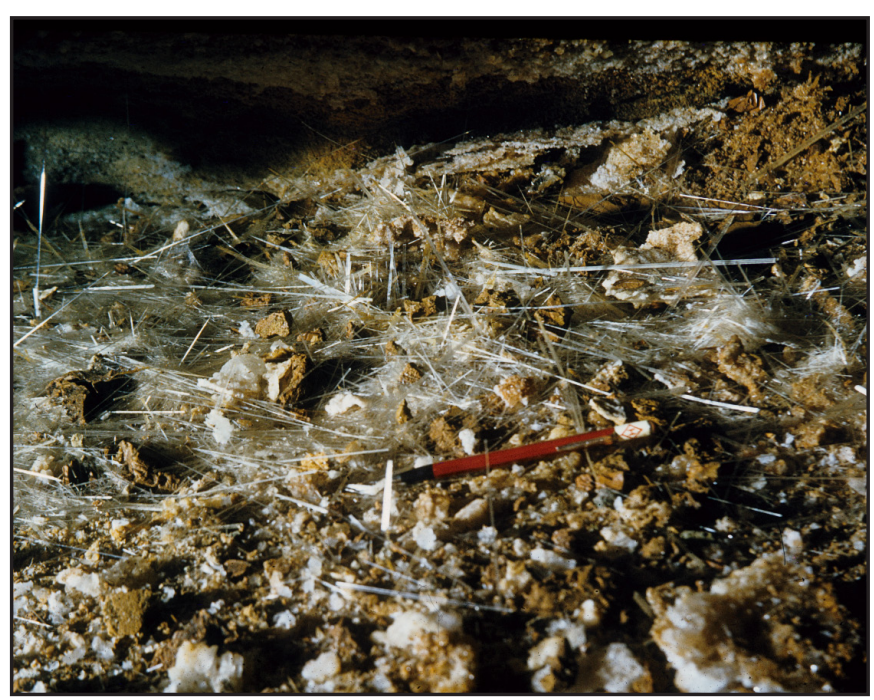

Fig. 29. Gypsum needles, Cumberland Caverns, Tennessee. Note pencil for scale (Photo by the author).

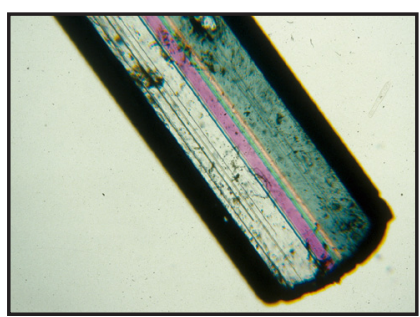

Fig. 30. A gypsum needle in polarized light. The color bands are interference colors and indicate different units of the multiply twinned crystal. The long axis of the crystal is the c-axis.

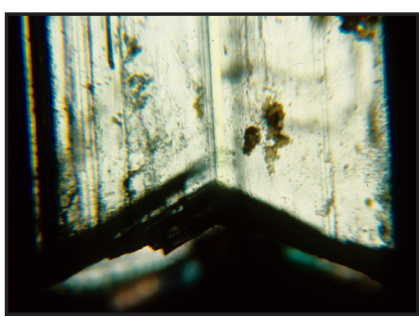

Fig. 31. Microscope view of the base of a gypsum needle in crossed-polarized light showing the reentrant formed by the swallow-tail twin. 


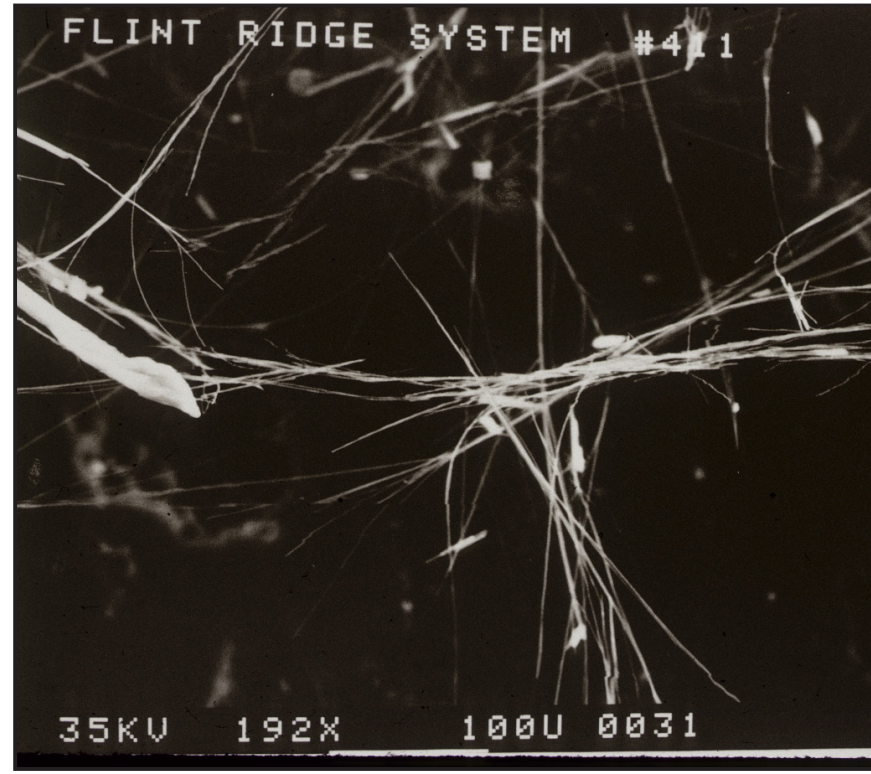

Fig. 32. Scanning electron microscope image of gypsum fibers from the Flint Ridge Section of Mammoth Cave, Kentucky. Scale bar at the bottom of the image is $100 \mu \mathrm{m}$.

Calculations of the equilibrium crystal form of gypsum (Van der Voort \& Hartman, 1991; Heijnen \& Hartman, 1991; Massaro et al., 2011) predict a tabular form with $\{010\}$ as the dominant face with some growth of prismatic forms. Investigations of the effects of impurities on gypsum growth (Franchini-Angela \& Rinaudo, 1989) show that the addition of $\mathrm{Na}$ encourages twinned growth but otherwise undeformed crystals. The incorporation of magnesium produces curved crystals. Cave gypsum grown in pools of water display a variety of forms with a dominance of prismatic forms (Fig. 28). However, gypsum deposited in air-filled caves typically has an acicular or fibrous habit with [001] as the fast growth direction although gypsum chandeliers contain crystals with a prismatic habit.

\section{Twinning: gypsum needles}

Gypsum needles (Fig. 29) are long, straight, clear crystals that are found growing at random an-
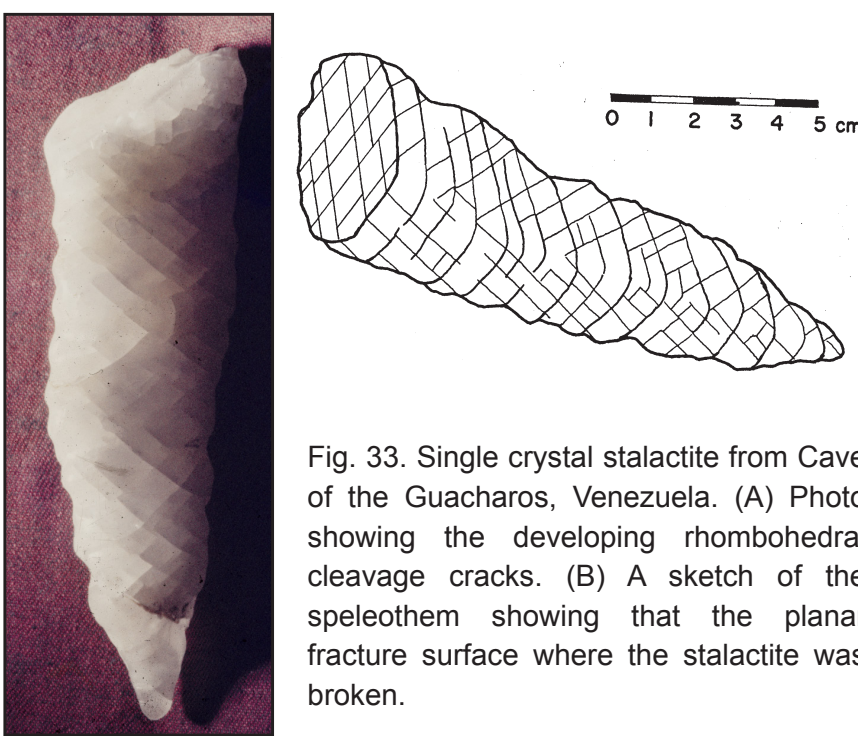

Fig. 33. Single crystal stalactite from Cave of the Guacharos, Venezuela. (A) Photo showing the developing rhombohedral cleavage cracks. (B) A sketch of the speleothem showing that the planar fracture surface where the stalactite was broken.

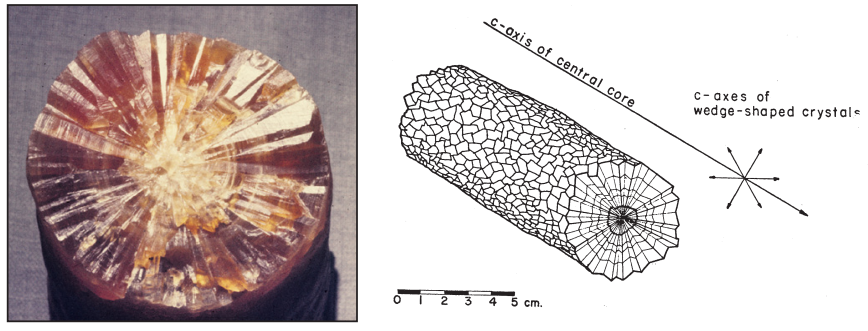

Fig. 34. Segment of stalactite from Cave of the Guacharos, Venezuela. (A) Photo of the cross section showing radial wedgeshaped crystals growing outward from the now recrystallized straw that acted as a substrate. (B) Sketch showing crystal orientations.

gles from clastic sediments (Onac et al., 1995). Microscopic examination under polarized light shows that the needles are twinned, sometimes multiply twinned (Fig. 30). The long axis of the needles is the fast-growth [001] direction (Fig. 31). Examination of the base of a needle where it emerges from the sediment reveals the mechanism of growth. The growth end of the needle is a re-entrant (or swallow-tail) twin. The resulting $\mathrm{V}$-notch is an ideal growth site as nutrients migrate upward from the sediment, supersaturated (presumably) with respect to gypsum, the gypsum is deposited in the notch while maintaining the twin structure. Growth pressure pushes the needle out of the sediment but the notch is maintained.

\section{Whisker growth: cave cotton}

Whiskers are single crystals with an extreme aspect ratio - very long but with very small cross sections. They appear to be perfect crystals that have grown along a single screw dislocation at low supersaturations (Morelock \& Sears, 1961). Some whiskers are straight but others grow in spirals. Whisker growth has been most extensively studied in the vapor growth of metals (Brenner, 1963) but whiskers have been observed in many other materials, even such refractory substances as aluminum oxide (DeVries \& Sears, 1959).

Cave gypsum commonly occurs as long silky fibers known variously as "cave cotton" "angel hair", "cave beards" or "cave rope". The gypsum fibers or

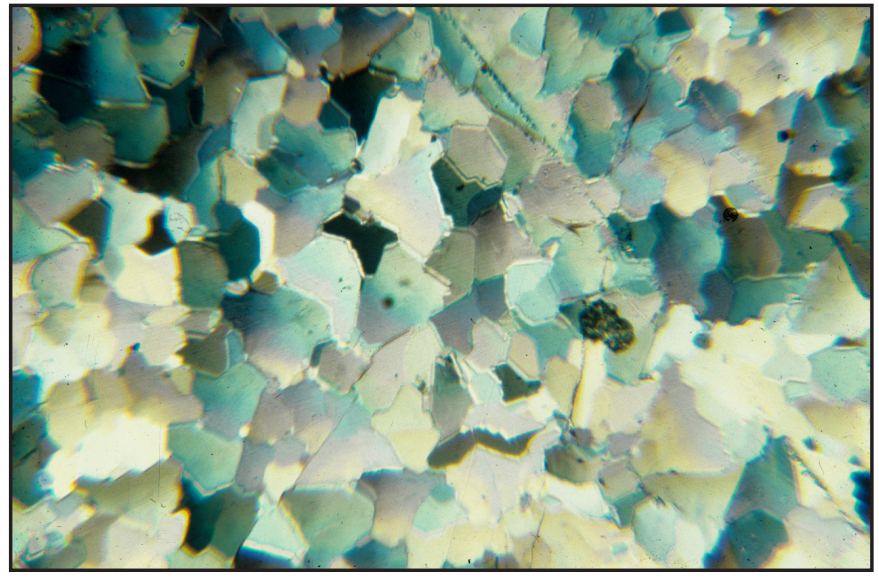

Fig. 35. Micrograph in crossed-polarized light of a thin section of a stalagmite from Butler Cave, Highland County, Virginia. The colors are due to interference. Note irregular grain boundaries and grain orientations. 
filaments are found with lengths of many centimeters but with typical thicknesses of only a few micrometers (Fig. 32). The gypsum fibers have the physical characteristics of whiskers. The definitive test would be to establish the presence of a single screw dislocation along the [001] fiber axis.

\section{AGGREGATES: POLYCRYSTALLINE BODIES: SPELEOTHEMS}

The ontogeny scheme (Table 1) uses the term "aggregates" for bodies composed on more than one crystal. In this sense, most individual speleothems are aggregates. Some fit rather neatly into the ontogeny scheme and some do not.

The external forms of speleothems fall into two categories - those whose external morphology is dictated by the idiosyncrasies of flowing or dripping water and those whose external form is dictated by the idiosyncrasies of crystal growth. Very substantial progress has been made on modeling the external forms of speleothems using bulk precipitation kinetics and fluid dynamics (e.g. Romanov et al., 2008). The internal structure is made up of mineral grains separated by grain boundaries. If all of the internal structure is aligned, except for the misalignment due to domain structure, the speleothem is composed of a single crystal and would be considered a mineral individual according to the ontogeny scheme. If the speleothem consists of multiple grains then the size and orientation of the grains must be described and interpreted. The pattern of mineral grains in rocks is known in petrology as texture (or fabric if the orientation of the grains is a primary consideration). The pattern of grains in ceramics and other materials is usually known as microstructure. The latter term is used in this review; it refers to the size, shape, and internal organization of grains on a micrometer to millimeter scale.

\section{The trade-off between two-dimensional and three-}

\section{dimensional nucleation}

The key to understanding the microstructure of calcite speleothems is the rather delicate balance between 3-dimensional nucleation and 2-dimensional growth. If conditions of fluid concentration and supersaturation are exactly right (the actual conditions for "exactly right" are not known), it is possible for a bulk speleothem such as a stalactite to deposit as a single crystal (Fig. 33A, B). The 10-cm stalactite broke along a single cleavage plane. As the specimen dried and cracked, the characteristic rhombohedral fracture pattern appeared. The axis of the stalactite corresponds to the fast-growth c-axis direction of calcite. Single crystal speleothems occur but are not common suggesting that "exactly right" conditions are highly restrictive.

Straw stalactites frequently grow as single crystals with the calcite $c$-axis oriented along the straw. At intermediate conditions of composition and supersaturation, straw stalactites can act as substrates for further growth with the overgrowth perpendicular to the original straw (Fig. 34A, B). The stalactite segment is composed of wedge-shaped crystals that have nucleated on a straw and then grew with their $c$-axes oriented radially around the straw. At still higher supersaturations, multiple nucleation occurs and the speleothem consists of a closely packed array of randomly oriented small crystal grains (Fig. 35).

\section{Columnar aggregates}

Texture (or fabric) of carbonate rocks is an important part of limestone/dolomite petrology and has important implications for the behavior of carbonate rocks as petroleum reservoirs. Carbonate rock fabrics have thus received a great deal of attention (e.g. Dickson, 1993). Fabrics of speleothems can be considered as only a special case.
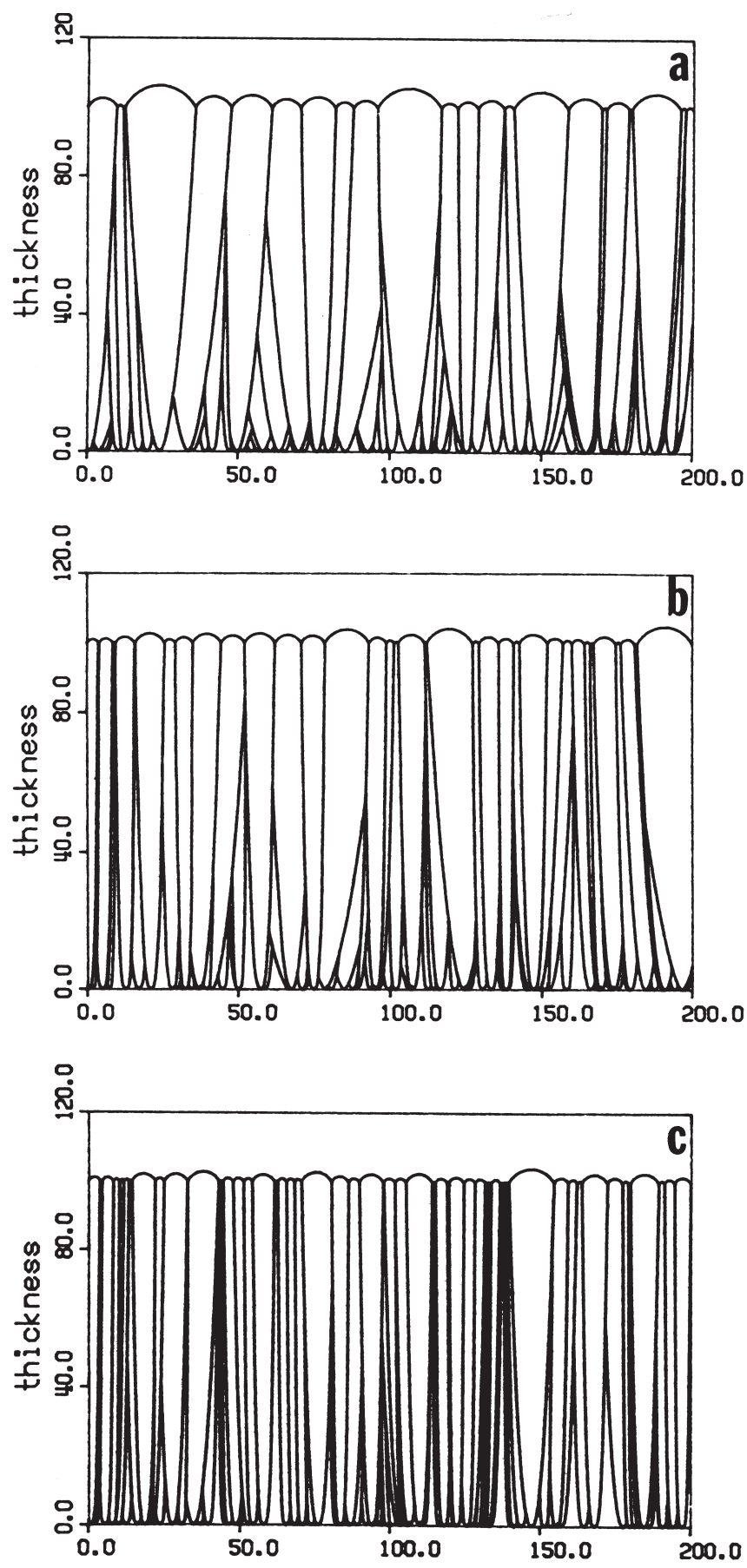

Fig. 36. Columnar aggregates grown from 100 seeds according to the power law statistical model with a wide distribution of the growth exponent, $\mathrm{n}(\sigma=1.0)$. Units are arbitrary. The mean growth exponent, $n_{0}$ is (a) 2.0; (b) 3.0; (c) 4.0. From Yang et al. (1987). 


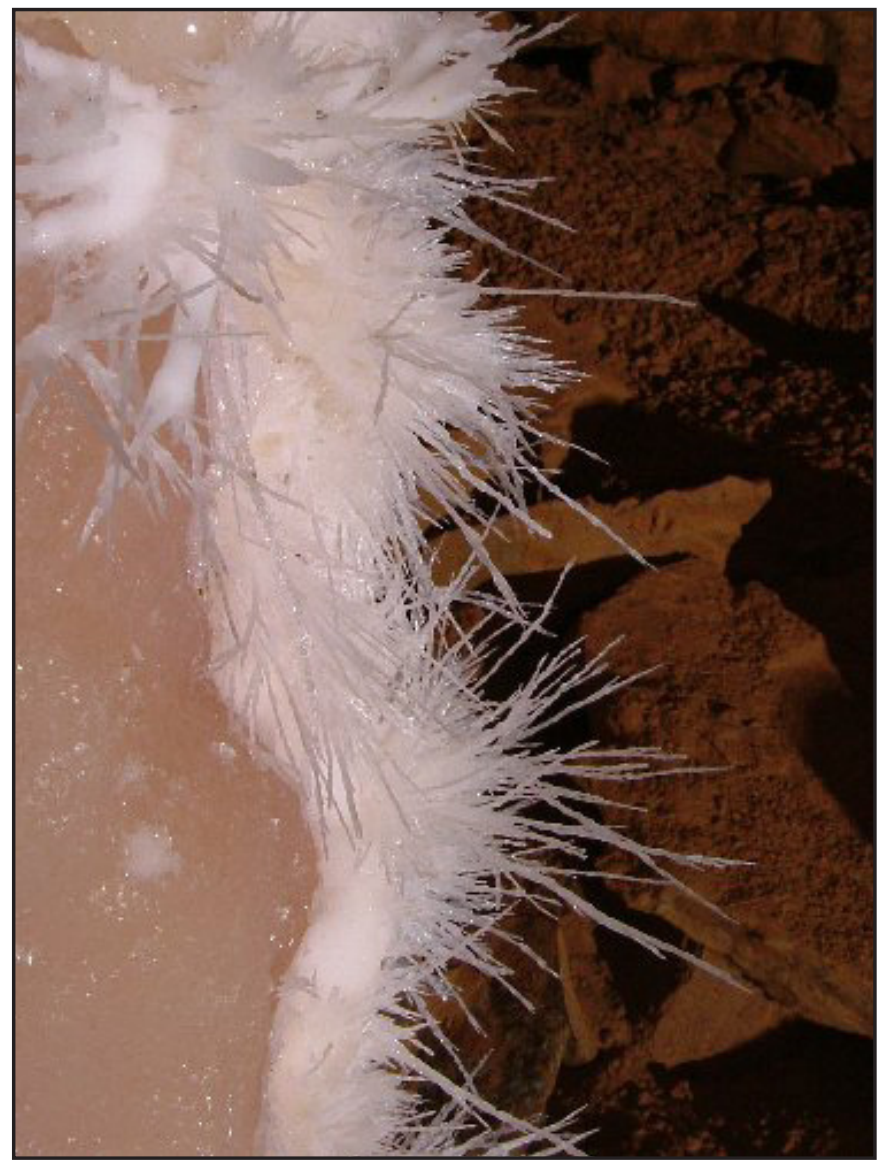

Fig. 37. Aragonite crystals growing from a flowstone-covered wall in the Blarney Stone Section of the Chestnut Ridge Cave System, Bath County, Virginia (Photo by Nevin W. Davis; Used with permission).

The majority of speleothems - flowstone, stalagmites, and most portions of stalactites - are composed of calcite that has deposited layer by layer from films of water that flow over the surface of the active speleothem. The most common fabric of these speleothems consists of calcite crystals oriented roughly perpendicular to the growth surface with a columnar or palisade pattern (Folk \& Assereto, 1976; Kendall \& Broughton, 1978). The columnar crystals are oriented with the $c$ axes perpendicular to the growth surface. Variations in growth rate and incorporation of humic substances often produces a growth banding parallel to the growth surface that cuts across the columnar crystals, often with no break in the crystallinity.

Moore (1962) proposed that the characteristic columnar fabric was a result of the fast growth of calcite along the $c$-axis. There may randomly oriented nuclei on the initial substrate, but those nuclei whose c-axes are oriented perpendicular to the growth surface grow faster and quickly squeeze out crystals growing in other directions although this is unlikely to be the only mechanism. The rate of growth and the details of crystal morphology relate to supersaturation and flow rate of the source water (González et al., 1992). Although the importance of flow rate has been questioned (Kendall, 1993), supersaturation is certainly part of the mechanism (Taylor \& Chafetz, 2004). Five distinct fabrics have been identified in Italian and Irish caves: columnar, fibrous, microcrystalline, dendritic, and calcareous tufa (Frisia et al., 2000). The columnar

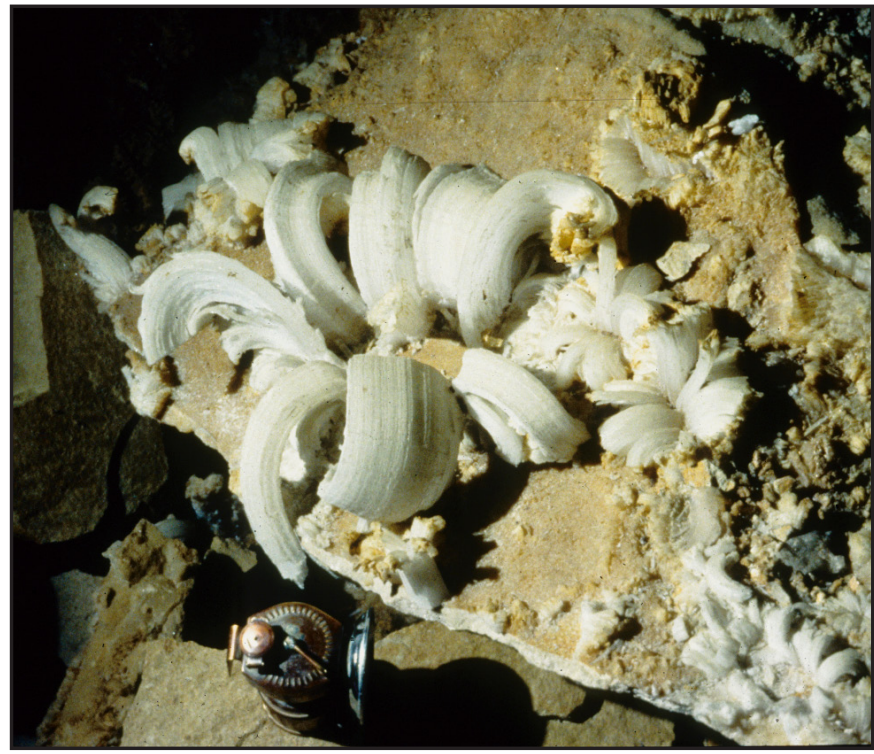

Fig. 38. Gypsum flower from Martin Ridge Cave in southcentral Kentucky. Note carbide lamp for scale (Photo by Joe Kearns; Used with permission).

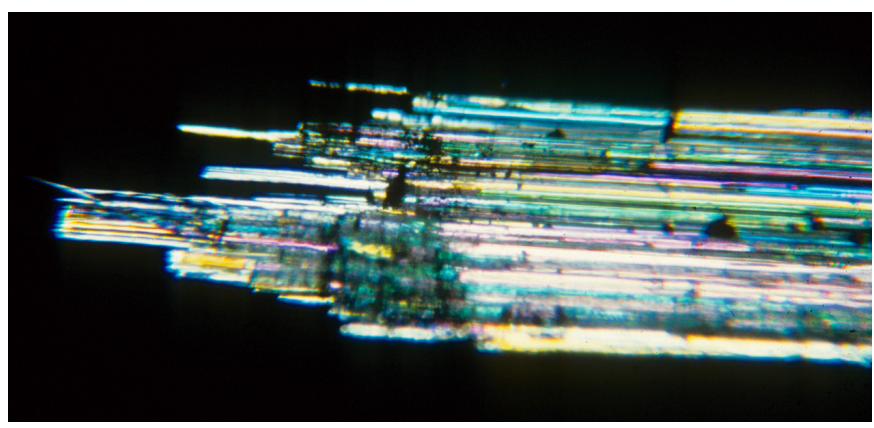

Fig. 39. Fragment of gypsum flower viewed under crossedpolarized light. The interference colors relate to fiber thickness. Note uniform colors along the axes of the fibers.

and fibrous fabrics result from constant flow rates at low supersaturation. The other fabrics result from variable flow rates and variable $\mathrm{CO}_{2}$ degassing. There are further variations in fabric resulting from the actions of microorganisms (Jones, 2010). What is apparent from recent work (Fairchild et al., 2010; Mattey et al., 2010) is that microstructure, microstratigraphy, isotopic composition, and trace element composition depend in a sensitive way on seasonal variations in flow rate, $\mathrm{CO}_{2}$-degassing rate, supersaturation, and bulk composition of the water. An understanding of all of these variables is necessary if paleoclimate records are to be read from speleothems.

It is possible to model columnar growth in a completely mechanistic way - no assumptions about chemistry or crystallography (Yang et al., 1987). The model assumes that growth originates on seeds scattered randomly over the substrate. Each seed then grows according to a power law with the exponent taken as a variable.

$$
y=k x^{n}
$$

The probability of a particular seed being assigned a specific value of $\mathrm{n}$ is a Gaussian distribution centered about the mean value $\mathrm{n}=\mathrm{n}_{0}$. Not only the rate 


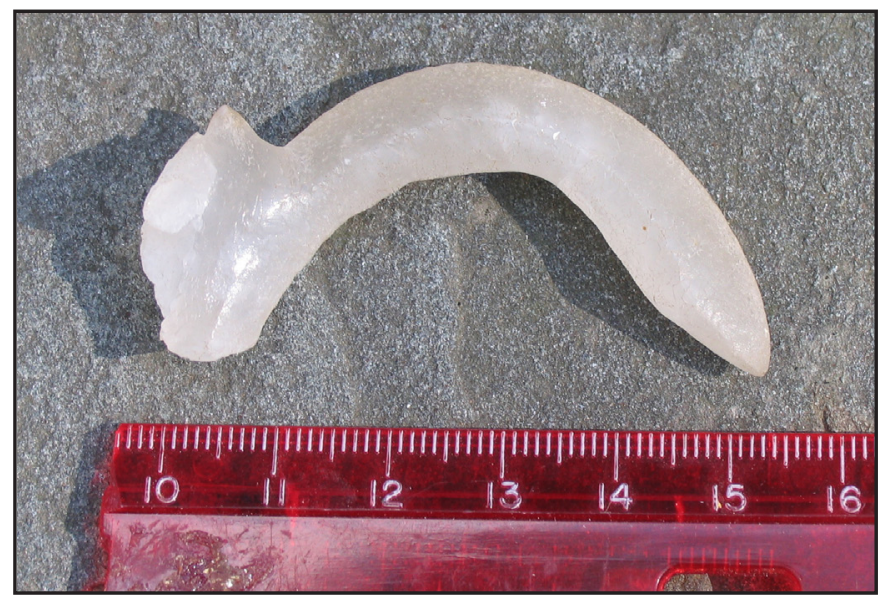

Fig. 40. Single crystal calcite helictite from Cueva del Guacharo, Venezuela. The scale in in $\mathrm{cm}$. Note that the crystal faces and the pinacoid faces at the tip can be discerned.

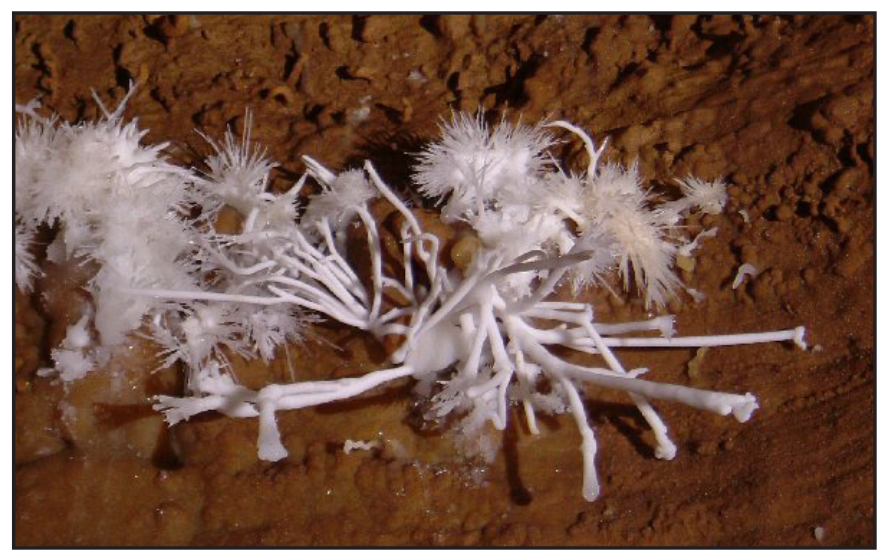

Fig. 41. Helictite with sprays of aragonite from the Blarney Stone section of the Chestnut Ridge Cave System, Burnsville Cove, Virginia (Photo by Nevin W. Davis; Used with permission).

of growth, but also the shape of each "crystal" in the aggregate is determined by the statistically determined value of $n$. A set of model runs (Fig. 36) shows the range of fabrics obtained for certain choices of the parameters. The model was constructed for semiconductor thin films, but could be applied to columnar calcite in speleothems.

\section{Branching aggregates: frostwork, anthodites, and aragonite bushes}

Aragonite in caves nearly always exhibits its characteristic [001] acicular habit. Bulk speleothems (stalactites, stalagmites, and flowstone) composed of aragonite are made up of closely packed acicular crystals which give the speleothem a satiny appearance when viewed in cross section. More frequently, aragonite appears as free-standing split crystals growing from nucleation sites on walls and ceilings (Fig. 37). Aragonite may take the form of many more-or-less parallel crystals as shown in Fig. 37 or aragonite may occur as sprays of crystals that have apparently grown from a common center such as those shown in Fig. 22. Larger and more complex structures are the rare aragonite trees. These range up to nearly a meter high and are composed a lacy intertwined set of aragonite crystals. The photograph of a dramatic example from Lechuguilla Cave, New Mexico, appears on page 130 of Widmer's (1991) book on Lechuguilla. From this example and from other published photographs of aragonite trees, the basic structure appears to portray dendritic growth.

The distinction between split crystal growth and dendrite growth is difficult. The lines of crystals, clearly originating from multiple nuclei, shown in Fig. 37 are multiply split. The radiating sprays of crystals originate from a common center which may or may not be a common nucleus. What has not been done, to this reviewer's knowledge, is to measure the exact crystallographic relationships between the components of the split crystals and the dendritic growths.

Within the ontogeny scheme, these speleothems would belong to the crystallictite group. This reviewer prefers the terms anthodite for the sprays of crystals originating from a common center (Fig. 22) and frostwork for the arrays of split crystals growing from a common surface but not a common center (Fig. 37). These are the end-member morphologies; transitional forms are common.

\section{Fibrous aggregates: gypsum flowers}

Gypsum is commonly found in dry caves in the form of gypsum flowers (occasionally called "oulophilites" (Fig. 38). These are composed of bundles of fibers with the fiber axis coincident with the [001] fast growth direction. In the polarizing light microscope, the "petals" of the gypsum flowers are seen as individual single crystals with their long axes in parallel (Fig. 39). The curvature of the "petals" arises because the fibers can slide over one another (Huff, 1940; Ghergari \& Onac, 1995).

The fluids from which the fibers of the flowers grow appear to seep through caves walls using the primary pores of the bedrock as a pathway. Thus each fiber would appear to have its nucleus on the pore from which the fluid emerged. Patches of higher permeability in the bedrock would result in higher growth rates at the center of the cluster of crystals thus forcing the fibers to expand outward and give the "petals" their curvature. Gypsum is nucleated and grown by evaporation of the solutions. Growth is sufficiently slow that the actual pore fluids have never been observed and the proposed mechanism remains hypothetical. What does seem likely is that the fibers are the result of growth at extreme supersaturations.

\section{Helictitic Forms}

Few speleothems appear in such variable form as those usually labeled "helictites". At one end of the scale are helictites which consist of a single calcite crystal (Fig. 40). This specimen is curved but retains the external 3-fold symmetry of calcite visible in the photograph. It broke along a single cleavage plane, but the cleavage plane was also curved. At the other end of the scale are very complex forms (Fig. 41) that are both polycrystalline and polymineralic. The bizarre growth patterns seen in helictites seem likely to be due to the influence of impurities although little is known about the chemistry. One common assemblage is a calcite helictite with an overgrowth of aragonite containing blobs of moonmilk at the tips. High $\mathrm{Mg}^{2+}$ concentrations in the seepage water build 
up to where they poison the calcite growth, thus forcing continued growth as aragonite. The solid solubility of $\mathrm{Mg}^{2+}$ in the aragonite structure is small, so the $\mathrm{Mg}^{2+}$ remains in solution to finally precipitate as one of the hydrated magnesium carbonate minerals as the solutions evaporate. It's a reasonable hypothesis, but hard data on the chemistry are lacking. To add further complication, there may be components of the speleothem that deposited as aragonite but which have since inverted to calcite.

Classification schemes such as shown in Table 1 are useful if the members of a particular classification slot have many common properties. Complex speleothems such as the helictites are sufficiently diverse in their growth patterns, mechanisms, mineralogy, and chemistry, that merely providing a label in not very instructive.

\section{THIRD AND FOURTH LEVELS: KORAS AND ENSEMBLES}

The ontogeny scheme allows for aggregates of aggregates, called koras. If a single speleothem is an aggregate of individual crystal grains, then a kora is an aggregate of speleothems. Ensembles are collections of koras. An Ensemble might be the entire assemblage of speleothems in a cave room or even in an entire cave. Other than providing labels, the third and fourth level organization of crystals does not contribute much to their understanding. Any ensemble of speleothems likely has deposited over a long period of time from solutions with chemistry that has varied in time and with evolving flow paths. Each such ensemble would need to be examined and interpreted. There is not much useful generalization to be had by labeling alone.

\section{SYMMETRY: ITS ROLE IN DESCRIBING POLYCRYSTALLINE BODIES}

Stepanov (1997) and Maltsev (1997) assign great importance to the symmetry properties of speleothem deposition. Stepanov draws on the Curie principle which states "if any cause leads to an effect, then the symmetry of the cause must be reflected in the symmetry of the effect." This rather broad concept is important in the design of materials but is usually expressed as the more restricted Neumann principle "the symmetry elements of any physical property of a crystal must include the symmetry elements of the point group of the crystal." This puts useful restrictions on physical property tensors such as elasticity and thermal expansion in addition to electrical and magnetic properties.

In the case of speleothems, the objects of interest are the speleothems themselves which are usually aggregates of mineral crystals and the solutions from which they grow. The sets of higher order symmetry operations known as the Curie groups include the symmetry of the sphere, the symmetry of a rightcircular cylinder, and the symmetry of a right-circular cone. In crystallographic notation, these groups would be $\infty \infty \mathrm{m}, \infty / \mathrm{m} \mathrm{m}$, and $\infty \mathrm{m}$ respectively. The $\infty$ symbol refers to an axis of rotation that permits all possible angles, i.e. the principal axis of the cylinder and cone and all diameters of the sphere. Addition of the concept of handedness increases the number of possible Curie groups to seven.

An aqueous solution has spherical symmetry so speleothems deposited from a water-body should reflect the spherical symmetry. Dripping water is controlled by a vector property, the gravitational field gradient, and should produce cylindrical symmetry as is indeed observed in stalactites and stalagmites. Deposition from capillary films should give a conical symmetry according to Stepanov.

There are deep mathematical implications to invariance under the operations of the Curie groups which allow consideration of the electrical and magnetic polar properties of crystals. However, it is not clear how one extracts further information about the growth of speleothems from symmetry considerations alone.

\section{CONCLUSIONS AND UNSOLVED PROBLEMS The current status of speleothem ontogeny}

The speleothem ontogeny concepts developed by Russian mineralogists and summarized in a well-organized manner by Self \& Hill $(2003,2005)$ provide a convenient organizational scheme for arranging new information on speleothem growth processes and have the further virtue of flagging blank areas where new knowledge is needed. Some of it, however, seems to be little more than applying new names to wellestablished concepts. Whether the highly formalized terminology will be useful remains to be seen.

Contrary to some opinions, the ideas and concepts (separate from the terminology) put forth as "ontogeny of minerals" are widely distributed in the western crystal growth literature. Some work continued through the relatively unproductive period of the 1920s when mineral ontogeny split from other parts of mineralogy in Russia. Work expanded in the 1940s and underwent explosive expansion in the late 1950s and 1960s. The applications were to crystals of technological importance and it is certainly true that relatively few of these concepts have been applied to the growth processes of speleothems. However, a great deal of information exists on the nucleation and growth of the most important speleothem minerals calcite, aragonite and gypsum; what is needed is a little lateral translation. What is clearly lacking has been observations of speleothems at the microstructure scale rather than only at the scale of the bulk speleothem.

\section{The future of speleothem ontogeny}

There are two main avenues along which great progress is possible. One - the most obvious - is to apply the powerful characterization tools now available to mineralogy and materials science specifically to speleothems. This means collecting and dissecting speleothem crystals so that their internal structures and compositions can be determined by polarized light microscopy, luminescence microscopy, scanning electron microscopy, and atomic force microscopy. The electron microprobe and the ion microprobe can be used to determine the distribution of trace elements that play such an important role in controlling growth habit. The instrumentation exists in many 
university laboratories; it is a question of an investigator with the necessary access developing an interest in the problem.

The second - and much more difficult - avenue to speleothem ontogeny is to develop tools for determining the microchemistry of thin aqueous films and water drops. As demonstrated by the laboratory studies of calcite, aragonite, and gypsum growth, the form and internal structure of the resultant speleothems are strongly determined by details of saturation state, bulk composition, and trace element composition of the depositing fluids. The volumes of these fluids are extremely small, or, in the case of gypsum, almost non-existent. In situ methods are necessary because sampling for later laboratory analysis would be extremely difficult and the chemistry might change during collection and transportation. The characterization instrumentation would tell us what is there. Microchemical analyses will tell us why it's there.

\section{ACKNOWLEDGEMENTS}

The review was prepared at the suggestion of the Commission on Cave Mineralogy of the International Speleological Union. Portions were presented at the Lake City convention of the National Speleological Society in 2008 and at the International Speleological Congress in Kerrville, Texas in 2009. I am grateful to Carol Hill, Charles Self, and Bogdan P. Onac for various suggestions. Thanks are extended to Philip C. Lucas and Nevin W. Davis of the Butler Cave Conservation Society for permission to use their photographs. Thanks are also due to Professor Patricia Dove of Virginia Tech for permission to use her AFM images.

\section{REFERENCES}

Astilleros J.M., Fernández-Diaz L. \& Putnis A., 2010 - The role of magnesium in the growth of calcite: An AFM study. Chemical Geology, 271: 52-58. http://dx.doi.org/10.1016/j.chemgeo.2009.12.011

Badino G., Calaforra J.M., Forti P., Garofalo P. \& Sanna L., 2011 - Present day genesis and evolution of cave minerals inside the Ojo de la Reina Cave (Naica Mine, Mexico). International Journal of Speleology, 40: 125-131. http://dx.doi.org/10.5038/1827-806X.40.2.5

Baker A., Genty D., Dreybrodt W., Barnes W.L., Mockler N.J. \& Grapes J., 1998 - Testing theoretically predicted stalagmite growth rate with Recent annually laminated samples: Implications for past stalagmite deposition. Geochimica et Cosmochimica Acta, 62: 393-404. http://dx.doi.org/10.1016/S0016-7037(97)00343-8

Balascio J.F. \& White W.B., 1972 - Hydrothermal growth of calcite from alkali carbonate solutions. Materials Research Bulletin, 7: 1461-1472. http://dx.doi.org/10.1016/0025-5408(72)90183-3

Bardsley W., Hurle D.T.J. \& Mullin J.B., 1979 - Crystal Growth: A Tutorial Approach. North Holland, Amsterdam, $408 \mathrm{p}$.
Berner R.A., 1975 - The role of magnesium in the crystal growth of calcite and aragonite from sea water. Geochimica et Cosmochimica Acta, 39: 489-504. http://dx.doi.org/10.1016/0016-7037(75)90102-7

Bevan D.J.M., Rossmanith E., Mylrea D.K., Ness S.E., Taylor M.R. \& Cuff C., 2002 - On the structure of aragonite - Lawrence Bragg revisited. Acta Crystallographica, B58: 448-456. http://dx.doi.org/10.1107/S0108768102003294

Blount C.W. \& Dickson F.W., 1973 - Gypsum - anhydrite equilibria in systems $\mathrm{CaSO}_{4}-\mathrm{H}_{2} \mathrm{O}$ and $\mathrm{CaSO}_{4}-\mathrm{NaCl}-\mathrm{H}_{2} \mathrm{O}$. American Mineralogist, 58: 323-331.

Bolling G.F. \& Tiller W.A., 1960a - Growth from the melt. I. Influence of surface intersections in pure metals. Journal of Applied Physics, 31: 13451350. http:/ / dx.doi.org/10.1063/1.1735840

Bolling G.F. \& Tiller W.A., 1960b - Growth from the melt. Part II. Cellular interface morphology. Journal of Applied Physics, 31: 2040-2045. http://dx.doi.org/10.1063/1.1735492

Bosbach D. \& Hochella M.F., Jr., 1996-Gypsum growth in the presence of growth inhibitors: a scanning force microscopystudy. Chemical Geology, 132: 227-236. http://dx.doi.org/10.1016/S0009-2541(96)00059-9

Bosbach D. \& Rammensee W., 1994 - In situ investigation of growth and dissolution on the (010) surface of gypsum by scanning force microscopy. Geochimica et Cosmochimica Acta, 58: 843-849. http://dx.doi.org/10.1016/0016-7037(94)90509-6

Bragg W.L., 1914 - The analysis of crystals by the X-ray spectrometer. Proceedings of the Royal Society of London A, 89: 468-489. http://dx.doi.org/10.1098/rspa.1914.0015

Brar N.S. \& Schloessin H.H., 1979 - Effects of pressure, temperature, and grain size on the kinetics of the calcite $\rightarrow$ aragonite transformation. Canadian Journal of Earth Sciences, 16: 1402-1418. http://dx.doi.org/10.1139/e79-125

Brenner S.S., 1963 - Metals. In: Gilman J.J. (Ed)., The Art and Science of Growing Crystals. New York: John Wiley: 30-54.

Buckley H.E., 1951 - Crystal Growth. John Wiley, New York, 571 p.

Budd D.A., 1988 - Aragonite-to-calcite transformation during fresh-water diagenesis of carbonates: Insights from pore-water chemistry. Geological Society of America Bulletin, 100: 1260-1270. http://dx.doi.org/10.1130/0016-7606 (1988) $100<1260: \mathrm{ATCTDF}>2.3 . \mathrm{CO} ; 2$

Buhmann D. \& Dreybrodt W., 1985 - The kinetics of calcite dissolution and precipitation in geologically relevant situations of karst areas. 1. Open systems. Chemical Geology, 48: 189-211. http://dx.doi.org/10.1016/0009-2541(85)90046-4

Burton W.K., Cabrera N. \& Frank F.C., 1951 The growth of crystals and the equilibrium structure of their surfaces. Transactions of the Royal Society of London, 242: 299-344. http://dx.doi.org/10.1098/rsta.1951.0006 
Cabrol P., 1978 - Contribution á l'étude du concretionnement carbonte des grottes du sud de la France. Morphologie, genese, diagenese. Mémoires du Centre d'Etudes et de Recherches Géologiques et Hydrologiques, 12, $275 \mathrm{p}$.

Cabrol P., Coudray J., Dandurand J.-L., \& Schott J., 1978 - Sur la possibilité de transformation naturelle calcite $\rightarrow$ aragonite dans les conditions ordinaires de température et de pression: reproduction expérimentale du phénomène. Compt Rendu des Academié de Sciences de Paris, 287: 411-414.

Cahn J.W. \& Hilliard J.E., 1959 - Free energy of a nonuniform system. III. Nucleation in a two-component incompressible fluid. The Journal of Chemical Physics, 31: 688-699. http://dx.doi.org/10.1063/1.1730447

Carlson W.D., 1983 - Aragonite-calcite nucleation kinetics: An application and extension of Avrami transformation theory. The Journal of Geology, 91: 57-71. http://dx.doi.org/10.1086/628744

Christoffersen J. \& Christoffersen M.R., 1990 - Kinetics of spiral growth of calcite crystals and determination of the absolute rate constant. Journal of Crystal Growth, 100: 203-211. http://dx.doi.org/10.1016/0022-0248(90)90623-S

Christoffersen M.R., Christoffersen J., Weijnen M.P.C. \& Van Rosmalen G.M., 1982 - Crystal growth of calcium sulphate dihydrate at low supersaturation. Journal of Crystal Growth, 58: 585-595. http://dx.doi.org/10.1016/0022-0248(82)90145-2

Cole W.F. \& Lancucki C.J., 1974 - A refinement of the crystal structure of gypsum $\mathrm{CaSO}_{4} \cdot 2 \mathrm{H}_{2} \mathrm{O}$. Acta Crystallographica, B30: 921-929. http://dx.doi.org/10.1107/S0567740874004055

Compton A.H., 1917 - The intensity of X-ray reflections and the distribution of the electrons in atoms. Physical Review 9: 29-57. http://dx.doi.org/10.1103/PhysRev.9.29

Cooke D.J. \& Elliott J.A., 2007 - Atomistic simulations of calcite nanoparticles and their interaction with water. Journal of Chemical Physics, 127: 104706. http://dx.doi.org/10.1063/1.2756840

Curl R.L., 1962 - The aragonite-calcite problem. National Speleological Society Bulletin, 21: 57-73.

Davis K.J., Dove P.M., \& De Yoreo J.J., 2000 - The role of $\mathrm{Mg}^{2+}$ as an impurity in calcite growth. Science, 290: 1134-1137.

http://dx.doi.org/10.1126/science.290.5494.1134

DeVries R.C. \& Sears G.W., 1959 - Growth of aluminum oxide whiskers by vapor deposition. Journal of Chemical Physics, 31: 1254-1257. http://dx.doi.org/10.1063/1.1730579

De Yoreo J.J. \& Dove P.M., 2004 - Shaping crystals with biomolecules. Science, 306: 1301-1302. http://dx.doi.org/10.1126/science.1100889

Dickson J.A.D., 1993 - Crystal growth diagrams as an aid to interpreting the fabrics of calcite aggregates. Journal of Sedimentary Petrology, 63: 1-17.

Dove P.M. \& Hochella M.F., Jr., 1993 - Calcite precipitation mechanisms and inhibition by orthophosphate: In situ observations by scanning force microscopy. Geochimica et Cosmochimica Acta, 57:705-714. http://dx.doi.org/10.1016/0016-7037(93)90381-6
Dreybrodt W., 1980 - Deposition of calcite from thin films of natural calcareous solutions and the growth of speleothems. Chemical Geology, 29:89-105. http://dx.doi.org/10.1016/0009-2541(80)90007-8

Dreybrodt W., 1981 - The kinetics of calcite precipitation from thin films $f$ calcareous solutions and the growth of speleothems: Revisited. Chemical Geology, 32: 237-245.

http://dx.doi.org/10.1016/0009-2541(81)90146-7

Dreybrodt W., 1999 - Chemical kinetics, speleothem growth and climate. Boreas, 28: 347:356.

Dreybrodt W., Buhmann D., Michaelis J. \& Usdowski E., 1992 - Geochemically controlled calcite precipitation by $\mathrm{CO}_{2}$ outgassing: Field measurements of precipitation rates in comparison to theoretical predictions. Chemical Geology, 97: 285-294. http://dx.doi.org/10.1016/0009-2541(92)90082-G

Effenberger H., Mereiter K. \& Zemann J., 1981 Crystal structure refinements of magnesite, calcite, rhodochrosite, siderite, smithsonite, and dolomite with discussion of some aspects of the stereochemistry of calcite type carbonates. Zeitschrift für Kristallographie, 156: 233-243. http://dx.doi.org/10.1524/zkri.1981.156.3-4.233

Elhadj S., De Yoreo J.J., Hoyer J.R., \& Dove P.M., 2006 - Role of molecular charge and hydrophilicity in regulating the kinetics of crystal growth. Proceedings of the National Academy of Sciences, 103: 19237-19242. http://dx.doi.org/10.1073/pnas.0605748103

Eugster H.P., 1971 - The beginnings of experimental petrology. Science, 173: 481-489. http://dx.doi.org/10.1126/science.173.3996.481

Fairchild I.J. \& Treble P.C., 2009 - Trace elements in speleothems as recorders of climate change. Quaternary Science Reviews, 28: 449-468. http://dx.doi.org/10.1016/j.quascirev.2008.11.007

Fairchild I.J., Spötl C., Frisia S., Borsato A. Susini J., Wynn P.M. Cauzid J. \& EIMF, 2010 - Petrology and geochemistry of annually laminated stalagmites from an Alpine cave (Obir, Austria): seasonal cave physiology. Geological Society, London, Special Publication, 336: 295-321.

Fairchild I.J. \& Baker A., 2012 - Speleothem Science. Wiley Blackwell, Chichester, UK, 432 p. http:/ /dx.doi.org/10.1002/9781444361094

Faust J.W. \& John H.F., 1961 - Germanium dendrite studies. Journal of the Electrochemical Society, 108: 855-863.

http://dx.doi.org/10.1149/1.2428238

Folk R.L. \& Assereto R., 1976 - Comparative fabrics of length-slow and length-fast calcite and calcitized aragonite in a Holocene speleothem, Carlsbad Caverns, New Mexico. Journal of Sedimentary Petrology, 46: 486-496.

Follner S., Wolter A., Helming K., Silber C, Bartels H. \& Follner H., 2002 - On the real structure of gypsum crystals. Crystal Research and Technology, 37: 207-218. http://dx.doi.org/10.1002/15214079(200202)37:2/3<207::AID-CRAT207>3.0.CO;2-L

Franchini-Angela M. \& Rinaudo C., 1989 - Influence of sodium and magnesium on the growth morphology of gypsum, CaSO $\bullet 2 \mathrm{H}_{2} \mathrm{O}$. Neues Jahrbuch für Mineralogie Abhandlungen, 160: 105-115. 
Frisia S., Borsato A., Fairchild I.J., \& McDermott F., 2000 - Calcite fabrics, growth mechanisms, and environments of formation in speleothems from the Italian Alps and southwestern Ireland. Journal of Sedimentary Research, 70: 1183-1196. http://dx.doi.org/10.1306/022900701183

García-Ruiz J.M., Melero-García E. \& Hyde S.T., 2009 - Morphogenesis of self-assembled nanocrystalline materials of barium carbonate and silica. Science, 323: 362-365.

http://dx.doi.org/10.1126/science.1165349

Ghergari L. \& Onac B.P., 1995 - The crystallogenesis of gypsum flowers. Cave and Karst Science, 22: 119-122.

Gilman J.J., 1963 - The Art and Science of Growing Crystals. John Wiley, New York, 493 p.

González L.A., Carpenter S.J., \& Kohmann K.C., 1992 - Inorganic calcite morphology: Roles of fluid chemistry and fluid flow. Journal of Sedimentary Petrology, 62: 382-399.

Grigor'ev D.P., 1965 - Ontogeny of Minerals. English translation of 1961 Russian original by Israel Program for Scientific Translations, Jerusalem, 250 p.

Gutjahr A., Dabringhaus H. \& Lacmann R., 1996a - Studies of the growth and dissolution kinetics of the $\mathrm{CaCO}_{3}$ polymorphs calcite and aragonite. I. Growth and dissolution rates in water. Journal of Crystal Growth, 158: 296-309. http:/ / dx.doi.org/10.1016/0022-0248(95)00446-7

Gutjahr A., Dabringhaus H. \& Lacman R., 1996b - Studies of the growth and dissolution kinetics of the $\mathrm{CaCO}_{3}$ polymorphs calcite and aragonite. II.The influence of divalent cation additives on the growth and dissolution rates. Journal of Crystal Growth, 158: 310-3115. http://dx.doi.org/10.1016/0022-0248(95)00447-5

Hacker B.R., Kirby S.H., \& Bohlen S.R., 1992 Time and metamorphic petrology: Calcite to aragonite experiments. Science, 258: 110-122. http://dx.doi.org/10.1126/science.258.5079.110

Heijnen W.M.M. \& Hartman P., 1991 - Structural morphology of gypsum $\left(\mathrm{CaSO}_{4} \cdot 2 \mathrm{H}_{2} \mathrm{O}\right)$, brushite $\left(\mathrm{CaHPO} \cdot 2 \mathrm{H}_{2} \mathrm{O}\right.$ and pharmacolite $\left(\mathrm{CaHAsO} \cdot 2 \mathrm{H}_{2} \mathrm{O}\right)$. Journal of Crystal Growth, 108: 290-300. http://dx.doi.org/10.1016/0022-0248(91)90376-G

Henderson G.E., Murray B.J., \& McGrath K.M., 2008 - Controlled variation in calcite morphology using simple carboxylic acids. Journal of Crystal Growth, 310: 4190-4198. http://dx.doi.org/10.1016/j.jcrysgro.2008.07.002

Henisch H.K., 1970 - Crystal Growth in Gels. The Pennsylvania State University Press, University Park, PA, 111 p.

Hill C.A. \& Forti P., 1997 - Cave Minerals of the World, $2^{\text {nd }}$ Ed. National Speleological Society, Huntsville, $\mathrm{AL}, 463 \mathrm{p}$.

Hillner P.E., Gratz A.J., Manne S., \& Hansma P.K., 1992 - Atomic-scale imaging of calcite growth and dissolution in real time. Geology, 20: 359-362.

http://dx.doi.org/10.1130/0091-7613(1992) 020<0359:ASIOCG > 2.3.CO;2

Hochella Jr. M.F. \& White A.F., 1990 - Mineral - Water Interface Chemistry. Reviews of Mineralogy, 23, 603 p.
Holland H.D., Kirsipu T.V., Huebner J.S. \& Oxburgh U.M., 1964 - On some aspects of the chemical evolution of cave waters. Journal of Geology, 72: 3667. http://dx.doi.org/10.1086/626964

Honess A.P. 1927 - The Nature, Origin, and Interpretation of Etch Figures of Crystals. John Wiley, New York.

House W.A., 1981 - Kinetics of crystallisation of calcite from calcium bicarbonate solutions. Journal of the Chemical Society, Faraday Transactions, 77: 341359. http://dx.doi.org/10.1039/f19817700341

House W.A. \& Tutton J.A., 1982 - An investigation of the heterogeneous nucleation of calcite. Journal of Crystal Growth, 56: 699-710. http://dx.doi.org/10.1016/0022-0248(82)90055-0

Huff L.C., 1940 - Artificial helictites and gypsum flowers. The Journal of Geology, 48: 641-659. http://dx.doi.org/10.1086/624919

Huizing T., Jarnot M., Neumeier G., Richards R.P., \& Staebler,G., Eds., 2003 - Calcite: The Mineral with the Most Forms. Lapis International, East Hampton, CT, $114 \mathrm{p}$.

Ikornikova N.Yu., 1973 - Growth characteristics of calcite crystals in aqueous solutions of carbonic acid. In: Lobachev A.N. (Ed)., Crystallization Processes under Hydrothermal Conditions. New York, Consultants Bureau: 93-112.

Inskeep W.P. \& Bloom P.R., 1985 - An evaluation of rate equations for calcite precipitation kinetics at $\mathrm{pCO}_{2}$ less than $0.01 \mathrm{~atm}$ and $\mathrm{pH}$ greater than 8. Geochimica et Cosmochimica Acta, 49: 21652180.

http://dx.doi.org/10.1016/0016-7037(85)90074-2

Inskeep W.P. \& Bloom P.R., 1986 - Kinetics of calcite precipitation in the presence of water-soluble organic ligands. Soil Science Society of America Journal, 50: 1167-1172. http://dx.doi.org/10.2136/ sssaj1986.03615995005000050015x

Jones B., 2010 - Microbes in caves: agents of calcite corrosion and precipitation. Geological Society, London, Special Publications, 336: 7-30. http://dx.doi.org/10.1144/SP336.2

Kazmierczak T.F., Tomson M.B., \& Nancollas G.H., 1982 - Crystal growth of calcium carbonate. A controlled composition kinetic study. Journal of Physical Chemistry, 86: 103-107. http://dx.doi.org/10.1021/j100390a020

Keller D.M., Massey R.E., \& Hileman O.E., Jr., 1978 - Studies on nucleation phenomena occurring in aqueous solutions supersaturated with calcium sulfate. Canadian Journal of Chemistry, 56: 831838. http://dx.doi.org/10.1139/v78-138

Kendall A.C., 1993 - Columnar calcite in speleothems: Discussion. Journal of Sedimentary Petrology, 63: 550-552.

Kendall A.C. \& Broughton P.L., 1978 - Origin of fabrics in speleothems composed of columnar calcite crystals. Journal of Sedimentary Petrology, 48: 519-538.

Lakshtanov L.Z., Bovet N., \& Stipp S.L.S., 2011 Inhibition of calcite growth by alginate. Geochimica et Cosmochimica Acta, 75: 3945-3955. http://dx.doi.org/10.1016/j.gca.2011.04.014

Langmuir D., 1997 - Aqueous Environmental Geochemistry. Prentice Hall, Upper Saddle River, NJ, $600 \mathrm{p}$. 
Larsen,K., Bechgaard K., \& Stipp S.L.S., 2010 - The effect of the $\mathrm{Ca}^{2+}$ to $\mathrm{CO}_{3}{ }^{2-}$ activity ratio on spiral growth at the calcite $\{10 \overline{1} 4\}$ surface. Geochimica et Cosmochimica Acta, 74: 2099-2109. http://dx.doi.org/10.1016/j.gca.2009.12.028

Lebrón I. \& Suárez D.L., 1996 - Calcite nucleation and precipitation kinetics as affected by dissolved organic matter at $25^{\circ} \mathrm{C}$ and $\mathrm{pH}>7.5$. Geochimica et Cosmochimica Acta, 60: 2765-2776.

Lebrón I. \& Suárez D.L., 1998 - Kinetics and mechanisms of precipitation of calcite as affected by $\mathrm{PCO}_{2}$ and organic ligands at $25^{\circ} \mathrm{C}$. Geochimica et Cosmochimica Acta, 62: 405-416.

Li H., Xin H.L. Muller D.A. \& Estroff L.A., 2009 - Visualizing the $3 D$ internal structure of calcite single crystals grown in agarose hydrogels. Science, 326: 1244-1247.

http://dx.doi.org/10.1126/science. 1178583

Liu M. \& Yund R.A., 1993 - Transformation kinetics of polycrystalline aragonite to calcite: new experimental data, modelling and implications. Contributions to Mineralogy and Petrology, 114: 465478. http://dx.doi.org/10.1007/BF00321751

Liu S.-T. \& Nancollas G.H., 1970 - The kinetics of crystal growth of calcium sulfate dihydrate. Journal of Crystal Growth, 6: 281-289. http://dx.doi.org/10.1016/0022-0248(70)90081-3

Liu S.-T. \& Nancollas G.H., 1973 - Linear crystallization and induction-period studies of the growth of calcium sulphate dihydrate crystals. Talanta, 20: 211-216.

http://dx.doi.org/10.1016/0039-9140(73)80268-1

Ma Y. \& Feng Q., 2011 - Alginate hydrogel-mediated crystallization of calcium carbonate. Journal of Solid State Chemistry, 184: 1008-1015. http://dx.doi.org/10.1016/j.jssc.2011.03.008

Maltsev V.A., 1997 - Overview of cave minerals onthogeny. Proceedings of the $12^{\text {th }}$ International Congress of Speleology, 1: 219-222.

Massaro F.R., Rubbo M., \& Aquilano D., 2011 Theoretical equilibrium morphology of gypsum $\left(\mathrm{CaSO}_{4} \cdot 2 \mathrm{H}_{2} \mathrm{O}\right)$. 2. The stepped faces of the main [001] zone. Crystal Growth and Design 11: 16071614. http://dx.doi.org/10.1021/cg101570c

Mattey D.P., Fairchild I.J., Atkinson T.C., Latin J.P., Ainsworth M., \& Durell R., 2010 - Seasonal microclimate control of calcite fabrics, stable isotopes and trace elements in modern speleothem from St. Michaels Cave, Gibraltar. Geological Society, London, Special Publications, 336: 323-344. http:/ /dx.doi.org/10.1144/SP336.17

McCauley J.W. \& Roy R., 1974 - Controlled nucleation and crystal growth of various $\mathrm{CaCO}_{3}$ phases by the silica gel technique. American Mineralogist, 59: 947-963.

McDermott F., 2004 - Paleo-climate reconstruction from stable isotope variations in speleothems: a review. Quaternary Science Reviews, 23: 901-918. http://dx.doi.org/10.1016/j.quascirev.2003.06.021

Meyer H.J., 1979 - Wachstumsgeschwindigkeit von Calcit aus Wässerigen Lösungen. Journal of Crystal Growth, 47: 21-28.

http://dx.doi.org/10.1016/0022-0248(79)90154-4
Meyer H.J., 1984 - The influence of impurities on the growth rate of calcite. Journal of Crystal Growth, 66: 639-646.

http://dx.doi.org/10.1016/0022-0248(84)90164-7

Moore G.W., 1962 - The growth of stalactites. National Speleological Society Bulletin, 21: 95-106.

Morelock C.R. \& Sears G.W., 1961 - Growth of whiskers by chemical reactions. Journal of Chemical Physics, 34: 1008-1009.

http://dx.doi.org/10.1063/1.1731624

Morse J.W., Arvidson R.S ., \& Lüttge A., 2007 - Calcium carbonate formation and dissolution. Chemical Reviews, 107: 342-381. http://dx.doi.org/10.1021/cr050358j

Nancollas G.H. \& Purdie N., 1964 - The kinetics of crystal growth. Quarterly Reviews (London), 18: 1-20. http://dx.doi.org/10.1039/qr9641800001

Nancollas G.H. \& Reddy M.M., 1971 - The crystallization of calcium carbonate. II. Calcite growth mechanisms. Journal of Colloid and Interface Science, 37: 824-830. http://dx.doi.org/10.1016/00219797(71)90363-8

Naumann C.F., 1856 - Elemente der Theoretischen Krystallographie. Verlag von Wilhelm Engelmann, Leipzig, 383 p.

Newnham R.E., 1974 - Domains in minerals. American Mineralogist, 39: 906-918.

Nilsson O. \& Sternbeck J., 1999 - A mechanistic model for calcite crystal growth using surface speciation. Geochimica et Cosmochimica Acta, 63: 217-225. http://dx.doi.org/10.1016/S00167037(99)00026-5

Ogino T., Suzuki T. \& Sawada K., 1990 - The rate and mechanism of polymorphic transformation of calcium carbonate in water. Journal of Crystal Growth, 100: 159-167. http://dx.doi.org/10.1016/00220248(90)90618-U

Onac B.P., Ghergari L., \& Gàl A., 1995 - Crystallographical studies on gypsum crystals in Ponoraş Cave [Pâdurea Craiului Mountains, Romania]. Theoretical and Applied Karstology, 8: 63-67.

Onac B.P. \& Forti P., 2011 a - Minerogenetic mechanisms occurring in the cave environment: an overview. International Journal of Speleology, 40: 79-98. http://dx.doi.org/10.5038/1827-806X.40.2.1

Onac B.P. \& Forti P., 2011b - State of the art and challenges in cave minerals studies. Studia UBB Geologia, 56: 33-42.

http://dx.doi.org/10.5038/1937-8602.56.1.4

Ota Y., Inui S., Iwashita T., Kasuga T. \& Abe Y., 1995 - Preparation of aragonite whiskers. Journal of the American Ceramic Society, 78: 1983-1984. http://dx.doi.org/10.1111/j.1151-2916.1995.tb08924.x

Palache C., 1943 - Calcite, an angle table and critical list. Harvard University Department of Mineralogy and Petrology Publication 259.

Paquette J. \& Reeder R.J., 1995 - Relationship between surface structure, growth mechanism, and trace element incorporation in calcite. Geochimica et Cosmochimica Acta, 59: 735-749. http://dx.doi.org/10.1016/0016-7037(95)00004-J

Pedersen B.F. \& Semmingsen D., $1982-$ Neutron diffraction refinement of the structure of gypsum, $\mathrm{CaSO}_{4} \cdot 2 \mathrm{H}_{2} \mathrm{O}$. Acta Crystallographica, B38: 1074-1077. http://dx.doi.org/10.1107/S0567740882004993 
Peiser H.S., 1966 - Crystal Growth. Proceedings of an International Conference on Crystal Growth, Boston, MA, June, 1966, Pergamon Press, Oxford, $851 \mathrm{p}$.

Perrette Y., 1999 - Les stalagmites: archives environnementales et climatiques à haute resolution. Karstologia, 34: 23-44.

Perry IV, T.D., Cygan R.T., \& Mitchell R., 2007 - Molecular models of a hydrated calcite mineral surface. Geochimica et Cosmochimica Acta, 71: 5876-5887. http://dx.doi.org/10.1016/j.gca.2007.08.030

Plummer L.N., Wigley T.M.L., \& Parkhurst D.L., 1978 - The kinetics of calcite dissolution in $\mathrm{CO}_{2}$-water systems at $5^{\circ}$ to $60^{\circ} \mathrm{C}$ and 0.0 to $1.00 \mathrm{~atm} \mathrm{CO}_{2}$. American Journal of Science, 278: 179-216. http://dx.doi.org/10.2475/ajs.278.2.179

Plummer L.N. \& Busenberg E., 1982 - The solubilities of calcite, aragonite and vaterite in $\mathrm{CO}_{2}-\mathrm{H}_{2} \mathrm{O}$ solutions between $O$ and $90^{\circ} \mathrm{C}$, and an evaluation of the aqueous model for the system $\mathrm{CaCO}_{3}-\mathrm{CO}_{2}-\mathrm{H}_{2} \mathrm{O}$. Geochimica et Cosmochimica Acta, 46: 1011-1040. http://dx.doi.org/10.1016/0016-7037(82)90056-4

Pokrovsky O.S., 1998 - Precipitation of calcium and magnesium carbonates from homogeneous supersaturated solutions. Journal of Crystal Growth, 186: 233-239.

http://dx.doi.org/10.1016/S0022-0248(97)00462-4

Prinz W., 1908 - Les cristallisations des grottes de Belgique. Nouveaux Mémoires de la Société belge de géologie, de paléontologie et d'hydrologie, Ser. 4, 90 p.

Railsback L.B., 2000 - An atlas of speleothem microfabrics. http://www.gly.uga.edu/railsback/speleoatlas/SAindex 1.html

Reddy M.M. \& Nancollas G.H., 1971 - The cystallization of calcium carbonate. I. Isotopic exchange and kinetics. Journal of Colloid and Interface Science, 36: 166-172.

http://dx.doi.org/10.1016/0021-9797(71)90161-5

Reddy M.M. \& Gaillard W.D., 1981 - Kinetics of calcium carbonate (calcite)-seeded crystallization: Influence of solid/solution ratio on the reaction rate constant. Journal of Colloid and Interface Science, 80: $171-178$.

http://dx.doi.org/10.1016/0021-9797(81)90173-9

Reddy M.M., Plummer L.N. \& Busenberg E., 1981 Crystal growth of calcite from calcium bicarbonate solutions at constant $P_{\mathrm{CO} 2}$ and $25^{\circ} \mathrm{C}$ : A test of a calcite dissolution model. Geochimica et Cosmochimica Acta, 45: 1281-1289.

http://dx.doi.org/10.1016/0016-7037(81)90222-2

Reeder R.J., 1983 - Crystal chemistry of the rhombohedral carbonates. In Carbonates: Mineralogy and Chemistry, R.J. Reeder, Ed., Mineralogical Society of America, Reviews of Mineralogy, 11: 1-47.

Reeder R.J., Fagioli R.O., \& Meyers W.J., 1990 - Oscillatory zoning of Mn in solution-grown calcite crystals. Earth Science Reviews, 29: 39-46.

Reznik I.J., Gavrieli I., Antler G. \& Ganor J., 2011 Kinetics of gypsum crystal growth from high ionic strength solutions: A case study of Dead Sea seawater mixtures. Geochimica et Cosmochimica Acta, 75: 2187-2199.

http://dx.doi.org/10.1016/j.gca.2011.01.034
Romanov D., Kaufmann G., \& Dreybrodt W., 2008 - Modeling stalagmite growth by first principles of chemistry and physics of calcite precipitation. Geochimica et Cosmochimica Acta, 72: 423-437. http://dx.doi.org/10.1016/j.gca.2007.09.038

Ruiz-Agudo E. \& Putnis C.V., 2012 - Direct observations of mineral-fluid reactions using atomic force microscopy: the specific example of calcite. Mineralogical Magazine, 76: 227-253.

http://dx.doi.org/10.1180/minmag.2012.076.1.227

Sears G.W., 1958 - Effect of poisons on crystal growth. Journal of Chemical Physics, 29: 1045-1048. http://dx.doi.org/10.1063/1.1744653

Sears G.W., 1961 - The origin of spherulites. Journal of Physical Chemistry, 65: 1738-1741. http://dx.doi.org/10.1021/j100827a015

Self C.A. \& Hill C.A., 2003 - How speleothems grow: An introduction to the ontogeny of cave minerals. Journal of Cave and Karst Studies, 65: 130-151.

Self C.A. \& Hill C.A., 2005 - An introduction to genetic mineralogy and the concept of "ontology of cave minerals". Proceedings of the $14^{\text {th }}$ International Congress of Speleology, 1: 125-129.

Siegel F.R., 1960 - The effect of strontium on the aragonite-calcite ratios of Pleistocene corals. Journal of Sedimentary Petrology, 30: 297-304.

Slyotov V.A., 1999 - Concerning the ontogeny of crystallictite and helictite aggregates of calcite and aragonite from the karst caves of southern Fergana. Cave Geology, 2: 197-208 (English translation of Russian paper appearing in 1985).

Speer J.A., 1983 - Crystal chemistry and phase relations of orthorhombic carbonates. In: Reeder R.J. (Ed)., Carbonates: Mineralogy and Chemistry, Mineralogical Society of America, Reviews of Mineralogy, 11: 145-190.

Stepanov V.I., 1997 - Notes on mineral growth from the archive of V.I. Stepanov (1924-1988). Proceedings of the University of Bristol Speleological Society, 21: 25-42.

Stepanov V.I., 1999 - Periodicity of crystallization processes in karst caves. Cave Geology, 2: 209-220 (English translation of Russian paper appearing in 1971).

Stephenson A.E., De Yoreo J.J., Wu L., Wu K.J., Hoyer J., \& Dove P.M., 2008 - Peptides enhance magnesium signature in calcite: Insights into origins of vital effects. Science, 322: 724-727.

http://dx.doi.org/10.1126/science.1159417

Stipp S.L. \& Hochella M.F., Jr., 1991 - Structure and bonding environments at the calcite surface as observed with $X$-ray photoelectron spectroscopy (XPS) and low energy electron diffraction (LEED). Geochimica et Cosmochimica Acta, 55: 1723-1736. http://dx.doi.org/10.1016/0016-7037(91)90142-R

Stipp S.L.S., 1999 - Toward a conceptual model of the calcite surface: Hydration, hydrolysis, and surface potential. Geochimica et Cosmochimica Acta, 63: 3121-3131. http://dx.doi.org/10.1016/S0016-7037(99)00239-2

Taylor P.M. \& Chafetz H.S., 2004 - Floating rafts of calcite crystals in cave pools, central Texas, U.S.A.: Crystal habit vs. saturation state. Journal of Sedimentary Petrology, 74: 328-341.

http://dx.doi.org/10.1016/S0016-7037(99)00239-2 
Teng H.H., Dove P.M., \& De Yoreo J.J., 2000 - Kinetics of calcite growth: Surface processes and relationships to macroscopic rate laws. Geochimica et Cosmochimica Acta, 64: 2255-2266.

http://dx.doi.org/10.1016/S0016-7037(00)00341-0

Thompson D.W. \& Pownall P.G., 1989 - Surface electrical properties of calcite. Journal of Colloid and Interface Science, 131: 74-82.

http://dx.doi.org/10.1016/0021-9797(89)90147-1

Van Beynen P., Bourbonniere R., Ford D., \& Schwarcz H., 2001 - Causes of colour and fluorescence in speleothems. Chemical Geology, 175: 319-341. http://dx.doi.org/10.1016/S0009-2541(00)00343-0

Van Cappellen P., Charlet L., Stumm W., \& Wersin P., 1993 - A surface complexation model of the carbonate mineral-aqueous solution interface. Geochimica et Cosmochimica Acta, 57: 3505-3518. http://dx.doi.org/10.1016/0016-7037(93)90135-J

Van Driessche A.E.S., Garcia-Ruiz J.M., DelgadoLópez J.M., \& Sazaki G., 2010 - In situ observation of step dynamics on gypsum crystals. Crystal Growth and Design, 10: 3909-3916. http://dx.doi.org/10.1021/cg100323e

Van der Voort E. \& P. Hartman 1991 - The habit of gypsum and solvent interaction. Journal of Crystal Growth, 112: 445-450.

http://dx.doi.org/10.1016/0022-0248(91)90321-U

Van Driessche A.E.S., Benning L.G., Rodriguez-Blanco J.D., Ossorio M., Bots P., \& García-Ruiz J.M., 2012 - The role and implications of bassanite as a stable precursor phase to gypsum precipitation. Science, 336: 69-72. http://dx.doi.org/10.1126/science.1215648

Van Rosmalen G.M., Daudey P.J., \& Marchée W.G.J., 1981 - An analysis of growth experiments of gypsum crystals in suspension. Journal of Crystal Growth, 52: 801-811.

http://dx.doi.org/10.1016/0022-0248(81)90379-1

Von Laue M., 1965 - Historical introduction. In: Henry N.F.M \& Lonsdale K. (Eds)., International Tables for X-ray Crystallography. Birmingham, UK, Kynoch Press: 1-5.

Wang C., 2008 - Control the polymorphism and morphology of calcium carbonate precipitation from a calcium acetate and urea solution. Materials Letters, 62: 2372-2380.

Wasylenki L.A., Dove P.M., \& De Yoreo J.J., 2005a Effects of temperature and transport conditions on calcite growth in the presence of $\mathrm{Mg}^{2+}$ : Implications for paleothermometry. Geochimica et Cosmochimica Acta, 69: 4227-4236. http://dx.doi.org/10.1016/j.gca.2005.04.006

Wasylenki L.E., Dove P.M., Wilson D.S., \& De Yoreo J.J., 2005b - Nanoscale effects of strontium on calcite growth: An in situ AFM study in the absence of vital effects. Geochimica et Cosmochimica Acta, 69: 3017-3027. http://dx.doi.org/10.1016/j.gca.2004.12.019

Westin K.-J. \& Rasmuson Å.C., 2005 - Crystal growth of aragonite and calcite in presence of citric acid, DTPA, EDTA and pyromellitic acid. Journal of Colloid and Interface Science, 282: 359-369. http://dx.doi.org/10.1016/j.jcis.2004.03.029
White W.B., 1994 - The anthodites from Skyline Caverns, Virginia: The type locality. National Speleological Society Bulletin, 56: 23-26.

White W.B., 1997 - Thermodynamic equilibrium, kinetics, activation barriers, and reaction mechanisms for chemical reactions in karst terrains. Environmental Geology, 30: 46-58. http://dx.doi.org/10.1007/s002540050131

White, W.B., 2004 - Paleoclimate records from speleothems in limestone caves. In: Sasowsky I.D. \& Mylroie J.E. (Eds)., Studies of Cave Sediments. New York, Kluwer Academic: 135-175.

White W.B. \& Brennan E.S., 1989 - Luminescence of speleothems due to fulvic acid and other activators. Proceedings of the $10^{\text {th }}$ International Congress of Speleology, Budapest: 212-214.

Whitlock H.P., 1909 - Calcites of New York. New York State Museum 63 ${ }^{\text {rd }}$ Annual Report, 4:1-190.

Widmer U., 1991- Lechuguilla Jewel of the Underground. Speleoprojects, Basel, Switzerland, 144 p.

Wiechers H.N.S., Sturrock P. \& Marais G.v.R., 1975 - Calcium carbonate crystallization kinetics. Water Research, 9: 835-845.

http://dx.doi.org/10.1016/0043-1354(75)90143-8

Witkamp G.J., Van der Eerden J.P., \& Rosmalen G.M., 1990 - Growth of gypsum. 1. Kinetics. Journal of Crystal Growth, 102: 281-289.

http://dx.doi.org/10.1016/0022-0248(90)90912-5

Wolthers M., Nehrke G., Gustafsson J.P. \& Van Cappellen P., 2012 - Calcite growth kinetics: Modeling the effect of solution stoichiometry. Geochimica et Cosmochimica Acta, 77: 121-134. http://dx.doi.org/10.1016/j.gca.2011.11.003

Wray J.L. \& Daniels F., 1957 - Precipitation of calcite and aragonite. Journal of the American Chemical Society, 79: 2031-2034. http://dx.doi.org/10.1021/ja01566a001

Yang B., Walden B.L., Messier R., \& White W.B., 1987 - Computer simulation of the cross-sectional morphology of thin films. Proceedings of the SPIE The International Society for Optical Engineering, 821: 68-76.

Ye Y., Smyth J.R. \& Boni P., 2012 - Crystal structure and thermal expansion of aragonite-group carbonates by single-crystal $X$-ray diffraction. American Mineralogist, 97: 707-712. http://dx.doi.org/10.2138/am.2012.3923

Zhang J.-W. \& Nancollas G.H., 1990 - Mechanisms of growth and dissolution of sparingly soluble salts. Reviews in Mineralogy, 23: 365-396.

Zhang J.-W. \& Nancollas G.H., 1992 - Influence of calcium/sulfate molar ratio on the growth rate of calcium sulfate dihydrate at constant supersaturation. Journal of Crystal Growth, 118: 287-294. http://dx.doi.org/10.1016/0022-0248(92)90073-R

Zhou G.T., Yao Q.Z., Ni J. \& Jin G., 2009 - Formation of aragonite mesocrystals and implication for biomineralization. American Mineralogist, 94: 293-302. http://dx.doi.org/10.2138/am.2009.2957 